\title{
Nanoparticles are More Successful Competitor than Antibiotics in Treating Bacterial Infections: A Review of the Literature
}

\author{
Roya Saddat Ghaderi, ${ }^{1,2}$, Monireh Kazemi ${ }^{3}$, Saman Soleimanpour ${ }^{1,2^{*}}$
}

1. Antimicrobial Resistance Research Center, Bu-Ali Research Institute, Mashhad University of Medical Sciences, Mashhad, Iran

2. Department of Microbiology and Virology, School of Medicine, Mashhad University of Medical Sciences, Mashhad, Iran

3. Chemistry Department, Payam-e Noor University, Mashhad, Iran

\section{ABSTRACT}

The crisis of antibiotic resistance in bacteria is one of the most important concerns of World Health Organization (WHO), which requires further global research and studies in order to develop more effective antimicrobial compounds. Nanoparticles as an alternative to antibiotics have been widely used to target bacteria and they are useful in the treatment of bacterial infections. In this narrative review study, the advantages of using nanoparticles against bacteria are discussed. Due to their unique properties compared to the bulk form, nanoparticles have a high potential to be used as carriers and adjuvants with the ability to strengthen the immune system and fight bacteria using several mechanisms simultaneously. Recently, a number of nanoparticle-based drugs have been designed and used for clinical use as an alternative to antibiotics. Despite special attention to nanoparticles, their antibacterial mechanisms are not very well known. However, in this study, we have examined in detail a number of accepted antibacterial mechanisms such as oxidative stress induced by ROS and the function of nanoparticles for releasing soluble metal ions. Further over, we also examined important factors affecting the antibacterial properties of nanoparticles, including size, charge, zeta potential, and surface morphology will be investigated too. The limitations of the research will also be discussed.

Keywords: Nanoparticles, Antimicrobial activity, Microbial resistance, Antibiotic

Received: 2020/05/03; $\quad$ Accepted: 2020/11/10; Published Online: 2020/01/10

\begin{tabular}{|c|c|}
\hline Corresponding Information: & $\begin{array}{l}\text { Dr. Saman Soleimanpour, Antimicrobial Resistance Research Center, Bu-Ali Research Institute, Mashhad University of Medical } \\
\text { Sciences, Mashhad, Iran. Email: Soleimanpours@mums.ac.ir }\end{array}$ \\
\hline & ion of the material just in noncommercial usages with proper citation. \\
\hline
\end{tabular}

Use your device to scan and read the article online

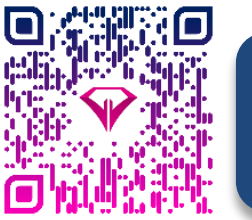

Ghaderi R S, Kazemi M, Soleimanpour S. Nanoparticles are More Successful Competitor than Antibiotics in Treating Bacterial Infections: A Review of the Literature. Iran J Med Microbiol. 2021; 15 (1) : 18-45

Download citation: $\underline{B i b T e X}$ | $\underline{\text { RIS }|~ E n d N o t e ~| ~ M e d l a r s ~|~ P r o C i t e ~| ~ R e f e r e n c e ~ M a n a g e r ~ \mid ~ R e f W o r k s ~}$
Send citation to:
Mendeley
(2) $\underline{\text { Zotero }}$
(1) RefWorks

\section{Introduction}

The emergence of antibiotic resistance in bacteria is one of the most important global health issues, and new research is needed around the world to develop more effective antimicrobial compounds (1). In the $21^{\text {st }}$ century, nanotechnology has become one of the most important and influential technologies in science worldwide. Nanomaterial engineering can open up new avenues of research and development in some fields including medicine, cosmetics, agriculture, environmental sciences, materials science, biomedical sciences, information, and food technology. It is also used to understand the changes in the physicochemical properties of nanomaterials (5). In fact, nanotechnology covers a wide range of sciences. In developing countries, it is important to invest and focus on this science to make improvements in the fields of health, water, energy, and environment $(6,7)$. Nanomaterials are structures that have at least one dimension on the nanometer scale (1-100 nanometers). On a broad spectrum, nanoparticles have shown impacts against both gram-positive and gram-negative bacteria (8). For example, zinc oxide nanoparticles could inhibit Staphylococcus aureus and silver nanoparticles have shown concentration- 
dependent antimicrobial activity against E. coli and Pseudomonas aeruginosa (9). Recently, nanoparticles (NPs) have drawn much attention because of their potential to be an alternative to antibiotics. The unique properties of nanoparticles compared to the balk form make them ideal for diagnosis, treatment, and antibiotic delivery systems. Rapid and sensitive detection of bacteria can be done by nanoparticlebased methods. In nanotechnology, there are new perspectives for the development of new formulations based on different types of nanoparticles with different sizes, shapes, and antimicrobial properties (11). Nanoparticles might seem to be a promising solution because not only can they fight against bacteria, but they can also act as carriers of antibiotics and natural antimicrobial compounds. This study focuses on the mechanisms of bacterial resistance and antibacterial activity of nanoparticles because it is very important to investigate the antibacterial mechanisms of these particles to produce more effective antimicrobial agents.

\section{Methods}

Standard requirements for literature reviews were conducted in the English language listed on health and medical electronic databases. The search words were: "Bacteria," "Nanotechnology," "Antibacterial," and "Nano" using PubMed, Scopus, Science Direct, and Google Scholar databases. Furthermore, manual searches of other relevant journals and keywords searches were performed. We have focused on published papers from 2010 to2020. After the initial review, the following types of articles were excluded: (i) studies that were not relevant to the main subject, (ii) papers which their full texts were not available, and (iii) repetitive publications and articles with similar results. We included articles that discussed the following topics: Articles that have examined the antibacterial mechanisms of nanoparticles on bacteria, as well as articles that explored the benefits and application of nanoparticles to combat bacteria, and finally studies that examined factors that affect the antibacterial mechanisms of nanoparticles.

\section{Results}

\section{Mechanisms of Bacterial Resistance to Antibiotics}

Bacterial resistance occurs due to the widespread use of antibiotics in prevention or treatment of diseases without proper medical symptoms, which has become a serious problem. This resistance has several reasons, all of which occurred due to the interaction of internal and external factors (12). External factors usually include antibiotics pressure and humancaused environmental changes, and internal factors include resistance from the genetic point of view and at the DNA level, as well as resistance from the biochemical point of view and at the protein level $(14,15)$.

\section{Advantages of using Nanoparticles in treating Bacterial Infections}

Bacteria can develop resistance to antimicrobials. Nanoparticles can combat microbes through various mechanisms that are simultaneously activated. Simultaneous mechanisms greatly reduce the possibility of several mutations in different genes, and most antibiotic resistance mechanisms are irrelevant to nanoparticle resistance mechanism; therefore, it is hoped that bacteria will be less resistant to nanoparticles (17). Nanoparticles are widely affected by the immune system. Many studies have shown that they have the ability to strengthen the immune system. The produced nanoparticles enter the body as a foreign substance, in return, the innate immune system responds immediately to these substances. This response can vary depending on the physicochemical properties of nanoparticles, including the size, charge, shape, and degree of hydrophobicity. As a result, the interaction of nanoparticles with various components of the immune system such as neutrophils, soluble proteins, and antigen-processing cells (APCs) depends on nanoparticle properties (18). Another case of stimulation of the immune system by nanoparticles is the development of allergic reactions. There are also many immune system reactions triggered by nanoparticles, which are produced by the production of inflammatory cytokines. Numerous studies have reported the induction of cytokines with different types of nanomaterials (gold colloids, dendrimers, polymers, lipid nanoparticles, etc.). Based on the body's immune response to nanoparticles, these substances can be used to treat cancers and autoimmune diseases, and act as a vaccine (19-20). Information about the different effects of nanoparticles on cells of the innate immune system (macrophages, dendritic cells, neutrophils, mast cells, and natural killer cells) and cells of the adaptive immune system ( $T$ cells and $B$ cells) helps us understand the immunological effects of nanomaterials. Innate immune system cells such as macrophages and dendritic cells cause the expression of inflammatory cytokines, activation of $T$ cell lymphocytes and activation of inflammasome. In addition, Nanoparticles can secrete histamine and increase cytosolic calcium ions by affecting on mast cells. Also nanoparticles are able to target natural killer cells (NK cell) to control their movement toward the tumor. By affecting the B cells of the adaptive immune system, the nanoparticles enhance immunity during vaccination and help target B-cell lymphoma without the need for chemotherapy. The interaction of nanoparticles with T lymphocytes can lead to Th1 
and Th2 responses as well as cytokine production and it helps development of nanoparticle-based products. Moreover, nanoparticles can act as a carrier for antibiotics synergistic factor and as a transvestite factor, which can ultimately facilitate therapeutic efficacy $(21,22)$. The combination of nanoparticles (NPs) and antimicrobial materials, such as antibiotics, peptides, or different biomolecules, has been known as one of the most effective methods targeting antibiotic resistance. Due to their small size, they can be used to treat infections caused by intracellular pathogens $(24,25)$. They also protect the drugs from the effects of enzymes and harmful chemical reactions. Nanoparticle carriers can help accurately target the infection site through antibiotics. Therefore, the unwanted side effects due to high doses and systemic side effects are minimized. With the use of these types of carriers, the drug concentration at the site of infection can reach the required effective level and be stable for a long time. Carrier nanoparticles can combine and transmit several antibacterial drugs together (26-29).

\section{The Problems of using Nanoparticles}

\section{Bacterial Resistance to Nanoparticles}

Further research has identified new aspects regarding the effects of nanoparticles on bacteria. While most previous studies have mentioned that nanoparticles, as an antibacterial agent, prevent the development of resistant bacteria, new information has recently been found to support the opposite. One study reported the increase in plasmid transport (such as RP4, PK2, and pCF10) by aluminum nanoparticles, which leads to the formation of resistant strains (30).

\section{Toxicity}

Local and systemic toxicity, as well as harmful effects on beneficial bacteria in the human body, are among the concerns discussed regarding the use of nanoparticles. Some NPs can cause hemolysis and interfere with blood coagulation pathways. One study has shown the deposition of silver nanoparticles in the liver, spleen, lungs, and other organs, which leads to organ damage. Intravenous nanoparticles may accumulate in the large intestine, lungs, bone marrow, liver, spleen, and lymphatic system, and their inhalation can cause toxicity in the lungs. Besides, several studies showed that nanoparticles do not have any dangerous toxicity in vivo conditions. The exact mechanism of the toxic effects of nanoparticles in laboratory conditions is unclear; therefore, further studies are required (31).

\section{Application of Nanoparticles}

Nanoparticles are used in different fields due to their unique properties and their effect on the bacteria. Different Types of nanoparticles have their characteristics, and each type is used for antibacterial purposes in certain parts of the body. Currently, there are some undergoing clinical trials on drugs with metalbased nanoparticles against bacterial infections with name Arikace, Lipoquin, Pulmaquin, Silvasorb, MAT2501 and QA-PEI. The cost of producing and using these nanoparticles is very high compared to traditional medicines; therefore, conventional treatments are more commonly used. Finally, nanoparticle-based drugs may be preferred in specific conditions and can increase the patients' quality of life (32).

\section{Antibacterial Mechanisms of Nanoparticles}

Despite special attention to nanomaterials, their antibacterial mechanisms have not been well known. But the accepted and important antibacterial mechanisms of nanoparticles against bacteria will be discussed here.

\section{The Function of Nanoparticles due to Oxidative Stress}

Oxidative stress induced by ROS is an important antibacterial mechanism of NPs. It can attack proteins and reduce the activity of some periplasmic enzymes. Moreover, reactive oxygen species are effective in increasing gene expression levels of oxidative proteins which are considered an important mechanism in bacterial cell apoptosis (33-34). It can destroy cellular components of the pathogens like membrane, DNA, and mitochondria, which can result in cell death (35). The study carried out by Ansari et al. confirmed that Al2O3 nanoparticles pass through the cell membrane and enter the cell, then nanoparticle-membrane interaction and due to intracellular oxidative stress, membrane integrity is damaged (36). Nanoparticles can also bind to TrxR and Trx active sites and interfere with the thioredoxin system, which is one of the most important redox systems of disulfide that is used by bacteria against oxidative stress, and leads to oligomerization and dysfunction of TrxR and TrxR (37).

\section{Performance of Nanoparticles by Producing Soluble Metal Ions}

The next important mechanism is releasing metal ions from metal oxide. Metal ions are slowly released from metal oxide and then absorbed through the cell membrane, followed by direct interaction with functional groups such as proteins and nucleic acids. This interaction alters cell structure, disrupts enzymatic activity, and interrupts the common physiological activity in bacterial cells (42).

\section{Mechanisms of Nanoparticles Penetration into Bacteria}

Diffusion: Nanoparticles can transmit reactive oxygen species to bacteria using diffusion. In a study, Pan et al. showed that iron oxide-graphene oxide nanoparticles could inactivate methicillin-resistant Staphylococcus aureus (MRSA) due to the production 
of large amounts of hydroxyl radicals and diffusion into bacterial cells (43).

Adsorption: Metal nanoparticles are released into the environment and bind to negatively charged groups in the bacterial cell membrane, such as carboxylic and phosphate groups, in a process known as biological adsorption. In a study, it was shown that the surface charges of copper nanoparticles significantly affect the adsorption of nanoparticles to membranes (46).

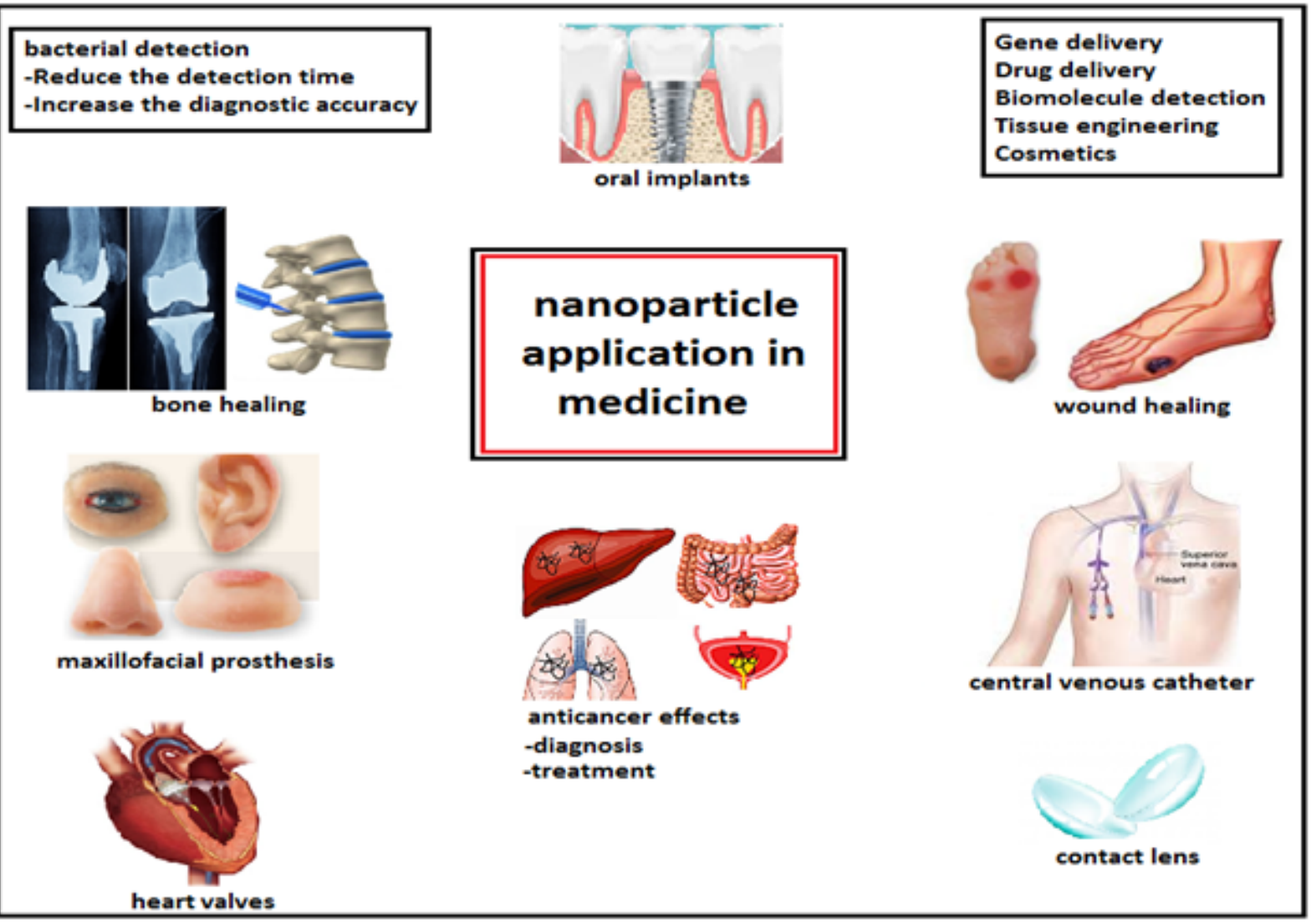

Figure 1. The nanoparticles application in medicine

The Effect of Nanoparticles on Different Parts of Bacteria

Interaction of Nanoparticles with the Cell Membrane and Bacterial Cell Wall

Studies showed that the interaction of nanoparticles with cell membranes in gram-positive and gramnegative bacteria is different due to their specific structure. Lipopolysaccharide (LPS) is a unique structure of the cell wall of gram-negative bacteria that creates a negatively charged region and absorbs nanoparticles. In contrast, teichoic acid is only expressed in the cell wall of gram-positive bacteria; therefore, nanoparticles are distributed along with the phosphate molecular structure and prevent their accumulation. Many studies have shown that nanoparticles have more antibacterial activity against gram-positive bacteria in comparison with gramnegative bacteria because the cell wall of gramnegative bacteria is composed of lipopolysaccharides, lipoproteins, and phospholipids. Nanoparticles can transmit reactive species of oxygen into bacteria through diffusion (47). The results of a study by Lucanhan et al. showed that selenium nanoparticles have a strong electrostatic repulsion compared to lipopolysaccharide and gram-negative bacterial membranes due to their very negative nature. Grampositive bacteria, on the other hand, have significantly less negative charge than gram-negative bacteria. Therefore, selenium nanoparticles are more likely to be deposited on the surface of gram-positive bacteria and cause bacterial death (39). Foster et al. confirmed that titanium oxide nanoparticles can adhere to the surface of bacterial cells to produce reactive oxygen species and damage the composition and structure of cell membranes, thereby they disrupt cell membrane function and cause cell leakage, and ultimately kill the bacteria (50). One of the most important functions of the cell membrane is the respiratory activity of bacteria. Studies have reported that nanoparticles also disrupt the respiratory activity of bacterial cell membranes (52). Figure 2 shows the attachment, penetration and cell lysis of bacteria with Kan-AuNPs treatment (83) 


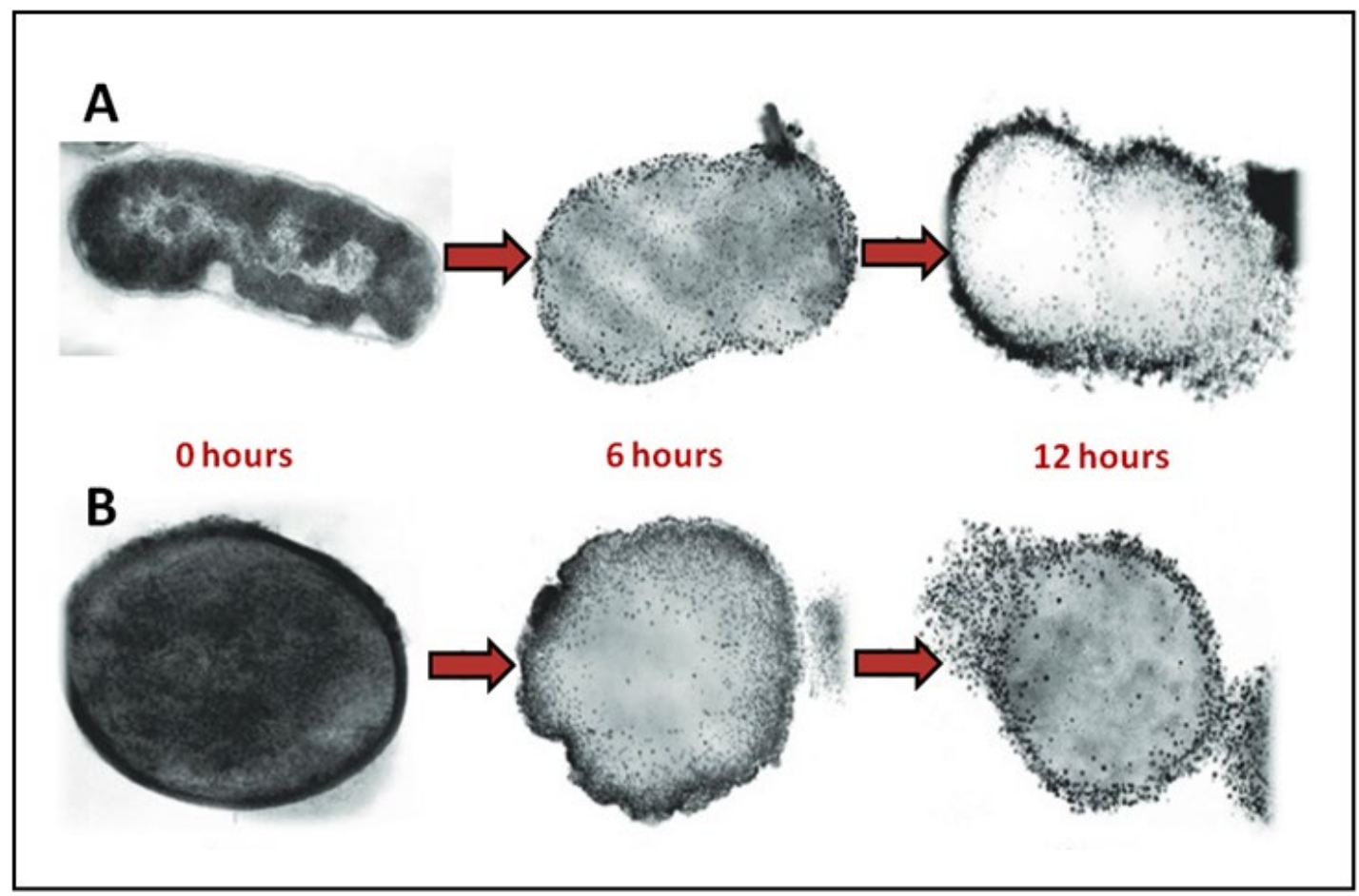

Figure 2. morphological changes in bacteria upon treating with Kan-AuNPs at different intervals of time. A) S. epidermidis bacteria treated with Kan-AuNPs B) E. aerogenes bacteria treated with Kan-AuNPs, Kan-AuNPs were found to attach and penetrate to the bacterial cell wall, disrupting the cellular environment and leading to cell lysis due to leakage of cellular components (83).

\section{Inhibition of Protein and DNA Synthesis in Bacteria}

In recent years, the effect of nanoparticles in the synthesis of bacterial proteins has received much attention from researchers. Su et al. investigated the effect of copper nanoparticles on nitrification of bacteria by maQing a significant change in the expression of key proteins. After entering the cell, proteomic bioinformatics analysis showed that copper nanoparticles regulate proteins involved in nitrogen metabolism, electron transfer, and material transport (54). Iron oxide nanoparticles were studied based on their strong tendency to form disulfide bonds and it was shown that they affect the metabolism and redox status of bacterial cells.

Nanoparticles can also stop protein and DNA synthesis in bacteria by inhibiting the combination of ribosomal subunits with tRNA or restricting ATPase activity to reduce ATP levels (55-56). Studies have indicated that nanoparticles can bind to proteins in cell membranes and create stable bonds. And as a result, they inactivate proteins that are involved in the production of membrane ATP and mediate the transfer of ions through cell membranes (10).

\section{Regulation of the Expression of Metabolic Genes by Nanoparticles}

The expression of metabolic genes is regulated by nanoparticles. Nanoparticles can also regulate cell membrane penetration and interfere with molecular pathways. Bacterial metabolic processes play a major role in bacterial growth and reproduction. They can also cause pathogenicity in bacteria. Therefore, targeted alteration of bacterial metabolic activity can be used to regulate bacterial pathogenicity For example, it has been observed that copper oxide nanoparticles can regulate the expression of proteins involved in bacterial nitrogen metabolism and significantly inhibit the activity of nitrate reductase and nitrite reductase. Wang et al. reported that silver nanoparticles can be covalently bonded to thiol derivatives and attached to some genetic components without any complicated modification process (47-48).

\section{Inhibition of Bacterial Biofilms Formation by Nanoparticles}

Prevention of biofilm formation by nanoparticles is an important mechanism because biofilms play an important role in the development of bacterial resistance. Genotypic and phenotypic properties of cells in biofilms are different from those of free cells, and these differences make them highly resistant to antibiotics (35). By the use of silver nitrate (AgNO3), Mohanti was able to produce silver nanoparticles with proper anti-biofilm effects (60). Pan et al. also reported that nanoparticles could affect the metabolic rate of bacterial communities. Bacterial metabolism is considered an important activity for biofilms. Based 
on other studies, nanoparticles can prevent the formation of biofilm by preventing bonding and icaAD transcription. Smaller nanoparticles are more capable of destroying bacterial biofilms due to the increase in surface-to-mass ratio (61). Due to the small size of nanoparticles, they can penetrate microbial cell walls and biofilm layers and cause irreversible damages to cell membranes and DNA. The shape of nanoparticles affects the destruction of biofilms. for instance, rodlike nanoparticles are more effective at destroying biofilms than spherical nanoparticles (64).

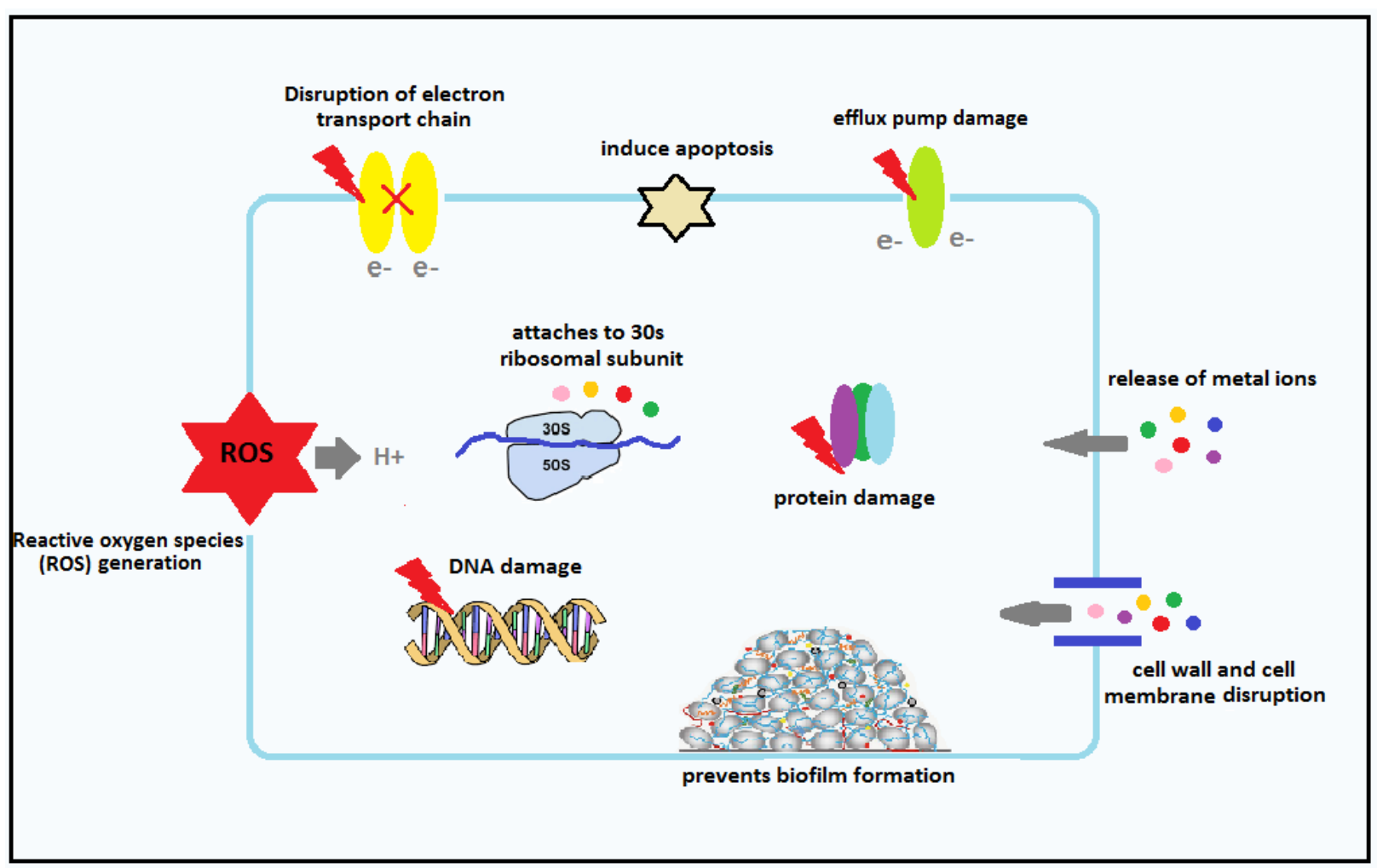

Figure 3. Antibacterial mechanisms of nanoparticles

Table 1. The antibacterial mechanisms of some nanoparticles against pathogenic bacteria. $(46,76-82)$.

\begin{tabular}{|c|c|c|}
\hline nanoparticles & Targeted bacteria & Mechanisms of antibacterial action \\
\hline Ag Nps & $\begin{array}{l}\text { Methicillin-resistant } \\
\text { Staphylococcus aureus, } \\
\text { Staphylococcus epidermidis. } \\
\text { Vancomycin-resistant Enterococcus } \\
\text { faecium and Klebsiella pneumoniae }\end{array}$ & $\begin{array}{l}\text {-Interference with electron and energy transfer through the membrane } \\
\text {-Prevention of DNA replication and electron transport chain in bacteria } \\
\text { and fungi } \\
\text {-Disruption of the cell surface and loss of membrane integrity } \\
\text {-Penetration into bacterial biofilms using an external magnetic field } \\
\text {-Generation of reactive oxygen species (ROS) } \\
\text {-Combination with antibiotics such as vancomycin, tetracycline and } \\
\text { ampicillin }\end{array}$ \\
\hline MgO NPs & $\begin{array}{l}\text { S. aureus, E. coli, Bacillus } \\
\text { megaterium, Bacillus subtilis }\end{array}$ & $\begin{array}{l}\text {-Generation of reactive oxygen species (ROS), lipid peroxidation, } \\
\text { alkaline, electrostatic interference }\end{array}$ \\
\hline $\mathrm{TiO}_{2} \mathrm{NPs}$ & S. aureus, E. coli & $\begin{array}{l}\text {-Generation of reactive oxygen species (ROS), superoxide radicals } \\
\text {-release of ion and binding to the thiol group in bacterial surface proteins } \\
\text {-DNA damage }\end{array}$ \\
\hline Zn NPs & $\begin{array}{l}\text { S. aureus, E. coli, listeria } \\
\text { monocytogenes, Salmonela }\end{array}$ & $\begin{array}{l}\text {-Generation of reactive oxygen species (ROS) } \\
\text {-Penetration of hydrogen peroxide produced at the surface of } \\
\text { nanoparticles into bacterial cells } \\
\text {-Prevention of enzymes product } \\
\text {-production of } \mathrm{Zn}^{2+} \text {, disruption of membrane and interference with } \\
\text { intracellular components }\end{array}$ \\
\hline Au NPs & $\begin{array}{l}\text { Methicillin-resistant } S \text {. aureus } \\
\text { (MRSA), Proteus mirabilis, } A \text {. } \\
\text { baumannii, E. coli, P. aeruginosa, } S \text {. } \\
\text { aureus }\end{array}$ & $\begin{array}{l}\text {-Generation of reactive oxygen species (ROS) } \\
\text {-Creating a hole in the bacterial cell wall } \\
\text {-DNA binding, DNA degradation and prevent transcription steps } \\
\text {-Osmotic balance and integrity of the bacterial cell wall } \\
\text {-Penetration into the biofilm } \\
\text {-Combined with antibiotics }\end{array}$ \\
\hline
\end{tabular}


24 Nanoparticles are More Successful Competitor than Antibiotics in Treating Bacterial Infections: A Review of the Literature

\begin{tabular}{|c|c|c|}
\hline nanoparticles & Targeted bacteria & Mechanisms of antibacterial action \\
\hline Fe NPs & S. aureus, E. coli, S. epidermidis & $\begin{array}{l}\text {-Generation of oxidative stress through the production of reactive } \\
\text { oxygen species (ROS) -superoxide radical -hydroxyl radical -hydrogen } \\
\text { peroxide -oxygen }\end{array}$ \\
\hline Al NPs & E. coli & $\begin{array}{l}\text {-Generation of reactive oxygen species (ROS) } \\
\text {-Cell wall disruption }\end{array}$ \\
\hline Bi NPs & Helicobacter pylori & $\begin{array}{l}\text {-Changing in Krebs cycle } \\
\text {-Interference with the metabolism of amino acids and nucleotides }\end{array}$ \\
\hline carbon-based NPs & $\begin{array}{l}\quad \text { E.coli, Salmonella enteric, E. } \\
\text { faecium, Streptococcus spp., } \\
\text { Shewanella oneidensis, } \\
\text { Acinetobacter baumannii, } \\
\text { Burkholderia cepacia, Yersinia } \\
\text { pestis, and K. pneumonia }\end{array}$ & $\begin{array}{l}\text {-Prevent energy metabolism } \\
\text {-Interference with electron transport chain } \\
\text {-Cell wall disruption }\end{array}$ \\
\hline CuO NPs & S. aureus, E. coli, B. subtilis & $\begin{array}{l}\text {-Generation of reactive oxygen species (ROS) } \\
\text {-Interference with biochemical processes within bacterial cells }\end{array}$ \\
\hline Se NPs & E. coli, P.aeruginosa, S. aureus & $\begin{array}{l}\text {-Generation of reactive oxygen species (ROS) } \\
\text { - Prevent the growth of bacteria }\end{array}$ \\
\hline
\end{tabular}

\section{Factors affecting the Antibacterial Mechanisms of Nanoparticles}

Physicochemical properties of nanoparticles including size, charge, zeta potential, surface morphology, and crystal structure, are important factors regulating the performance of nanoparticles on bacterial cells. Also, environmental conditions and duration of exposure to other factors affect the antibacterial effects of nanoparticles. (65). Current research has shown that the size of a nanoparticle greatly affects its antibacterial activity. Smaller nanoparticles have more specific surface areas and are more likely to come in contact with bacterial cell membranes compared to large nanoparticles and polymers (66). Since the shape is an important factor in antimicrobial activity, nanoparticles with different shapes can damage bacterial cells by interacting with pre-plasmic enzymes. Although nanoparticles are reported to have different forms such as bars, wires, tubes, scales, and discs, they are mostly seen spherically. Nanotubes and nanorods seem to be more effective than other forms to kill the bacteria. This indicates that the effect of antibacterial activity is due to the specific surface area (67-68). By increasing the roughness of nanoparticles, the size and ratio of surface to mass causes the absorption of bacterial proteins and consequently reduces the bacterial adhesion of nanoparticles (69). Recent studies have shown that surface charge in nanoparticles has a significant impact on the association between bacteria and nanoparticles. This connection is due to the electrostatic attraction between positively charged nanoparticles and negatively charged bacterial cell membranes. However, at higher concentrations, negatively charged nanoparticles have a good level of antibacterial activity due to molecular overcrowding, which leads to proper interaction between nanoparticles and bacterial cells (70). For example, positively charged polystyrene nanoparticles disrupt the electron transfer chain in bacteria. A study on $E$. coli bacteria also reported that bacteria with mutations in the ubiquinone gene were more sensitive to positively charged nanoparticles (67). A wide range of studies has also shown that different environmental conditions cause significant differences in the antimicrobial activity of nanoparticles. For instance, ambient temperature has different impacts on antibacterial activity due to its effects on the production of reactive oxygen species. Additionally, the $\mathrm{pH}$ of the environment affects antimicrobial activity. It appears that acidic conditions bind nanoparticles to the bacterial cell walls. Furthermore, for example with decreasing $\mathrm{pH}$, the rate of dissolution of zinc oxide nanoparticles increases, which causes an increase in antimicrobial properties (73). According to studies, nanoparticles are a good alternative to antibiotics and have a high potential to solve the problem of the emergence of resistant bacteria; because some nanoparticles have no cellular toxicity or they have very low toxicity. Also, new methods for nanoparticle production do not involve high-risk and complex processes (74).

\section{Research Limits}

The antibacterial mechanisms of nanoparticles are still unknown. Many studies, for example, attribute antibacterial activity to oxidative stress or reactive oxygen species, while for some nanoparticles, including magnesium oxide nanoparticles, the antibacterial mechanism may not regulate bacterial metabolism; therefore, one of the issues to be addressed in future studies is to further investigate the antibacterial mechanisms of nanoparticles. Lack of integrated standards is another limitation regarding antibacterial mechanisms of nanoparticles. In particular, the use of different bacterial strains, operating time, and nanoparticle properties have not been standardized in various studies, which makes it difficult to compare antibacterial activities. In addition, sensitive bacterial strains are often used to 
accurately determine the antibacterial activity of nanoparticles. Other limitations include the complex structure of bacterial cell membranes and the lack of research methods for their laboratory studies. Moreover, laboratory models cannot replicate in vivo conditions accurately; therefore, it is impossible to estimate the antibacterial performance of nanoparticles through laboratory bacterial cell culture alone. Many questions remain unanswered, questions regarding the toxicity of nanoparticles as well as how nanoparticles pass through the bacterial cell membrane which all will need to be answered in future researches.

\section{Conclusion}

Since in recent years antibiotic resistance has accelerated, fighting infectious diseases and treating patients have become challenging, which leads to serious complications and death. According to several studies, nanoparticles are a suitable replacement for antibiotics and it seems they could solve the problem of the emergence of resistant bacteria; since nanoparticles either have no cytotoxicity or are usually very low in toxicity. Also, their production methods do not involve high-risk and complex processes. Nowadays, with the help of green chemistry, smaller and more efficient nanoparticles are produced by simple and clean methods with acceptable antibacterial properties (71).

We hope that this review study can provide a better perspective for researchers and an in-depth study of the antibacterial mechanisms of nanoparticles will lead to the production of effective antibacterial particles with no cytotoxicity.

\section{Acknowledgment}

The technical support for this work has been provided by Mashhad University of Medical Sciences.

\section{Compliance with Ethical Standards}

The authors declare that they have no conflict of interest.

\section{Conflict of Interest}

The autors dec;ared no conflict of intersts 


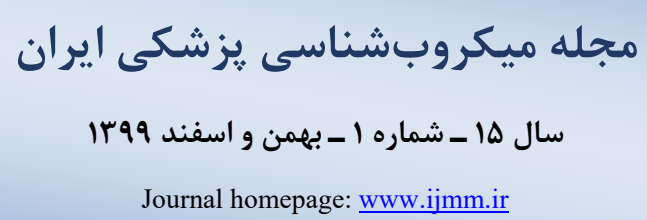

\title{
نانوذرات، رقيبى موفقتر از آنتىبيوتيكها براى درمان عفونتهاى باكتريايى: مقالله مرورى
}

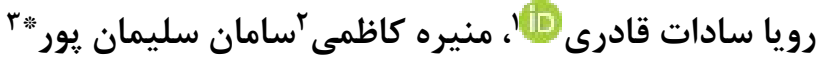

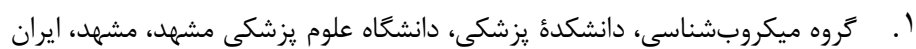

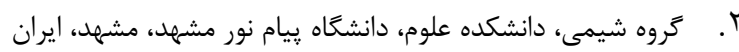

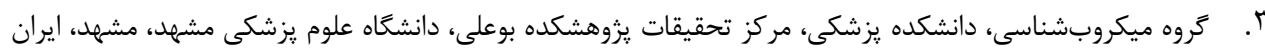

\begin{tabular}{|c|c|}
\hline جكيله & اطلاعات مقاله \\
\hline 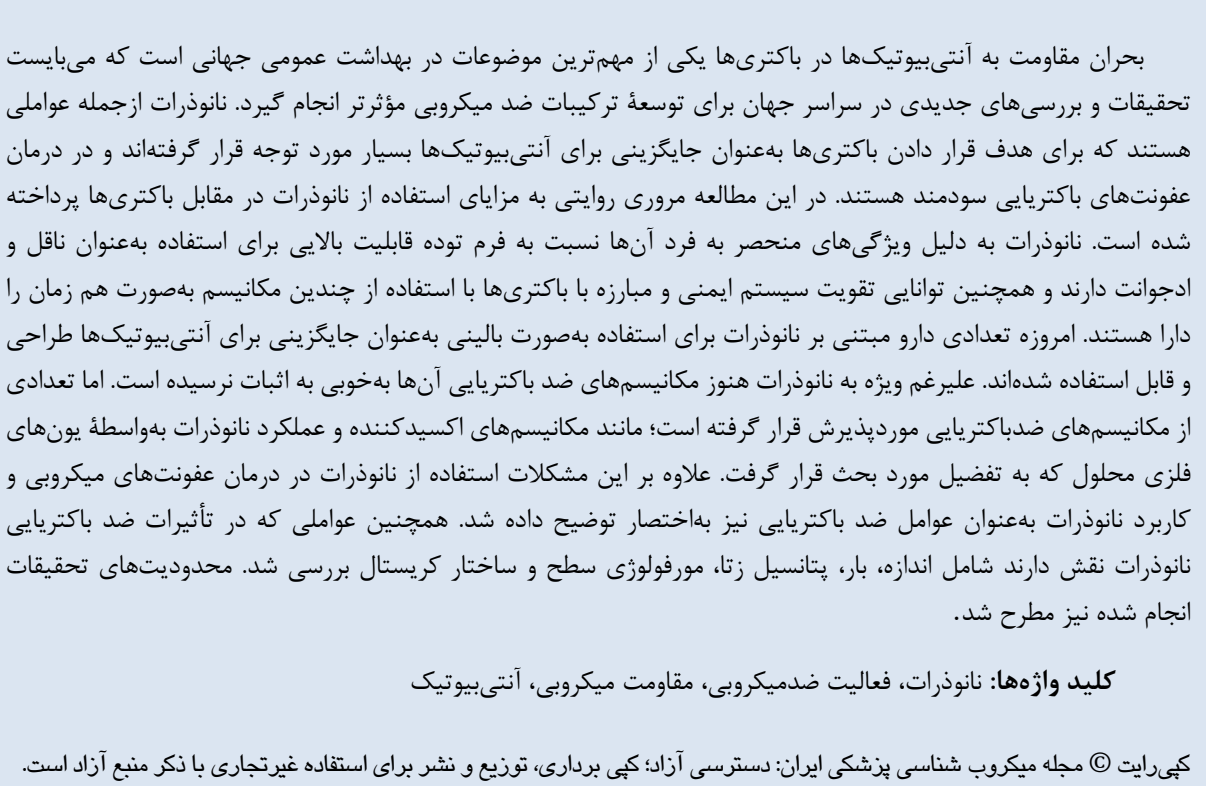 & 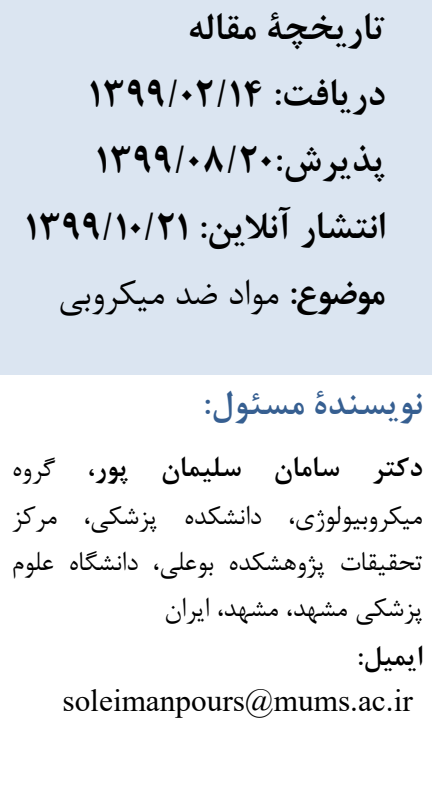 \\
\hline
\end{tabular}

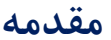

هستند اغلب سه نقطه از باكترى را مورد هدف قرار مىدهند: سنتز ديواره سلولى، مراحل يروتئينسازى و همجنين تكثير DNA. متأسفانه مقاومت باكتريايى مىتواند در برابر هر يك از اين موارد رخ رهدئ دهد. مكانيسمهاى مقاومت مىتواند شامل بيان آنزيمهايى باشد كه آنتىبيوتيكها را تخريب مى كند، مانند مقاومت نسبت به م-لاكتامازها و آمينوكليكوزيدها و يا اصلاح اجزاى ديواره سلولى مانند مقاومت در برابر ونكومايسين و همجنين تغيير در ريبوزومها مانند مقاومت در برابر تتراسايكلين و بيان افلاكس پميّها كه ممكن است اين مكانيسمهاى مقاومت همزمان و يا بلهورت جداكانه در باكترىها رخ دهند (ب). بيشتر مكانيسمهاى مقاومت در برابر آنتىبيوتيكها ارتباطى با مكانيسم
باكترىها عامل اصلى عفونتهاى مزمن و مرگىمير هستند كه

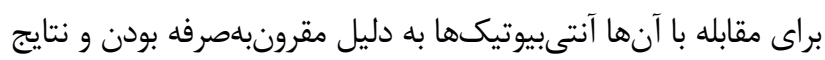
اثربخش، بهعنوان روش درمانى مطلوب مورد استفاده قرار مى ميرند. با بانيا اينوجود، مطالعات متعدد شواهدى را ارائه دادهاند كه نشان مى مدهد

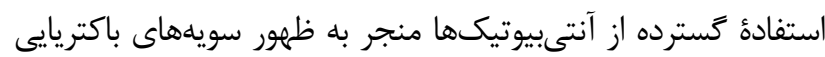

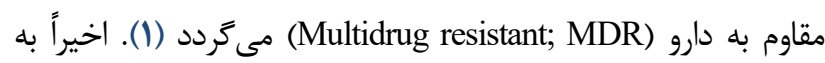
دليل سوءمصرف آنتىبيوتيكها، سوير باكترىها يعنى باكترىهايى كه

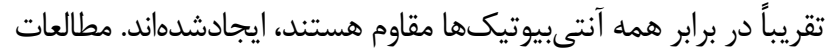
نشان داده است كه اين باكترىها داراى يك زن مقاومت به نام NDM-1 هستند (Y). گروههاى عمده آنتىبيوتيكهايى كه در حال استفاده 
اين مقاله مرورى با جستجوى كليد وازمهاى "Bacteria" "Nanotechnology" دادهol انجام گرفت. جستجوى دستى ساير مجلات مرتبط نيز انجام شد. اين

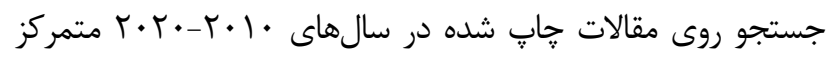
شده است. يس از بررسى اوليه، براى انتخاب مستندات مورد استفاده

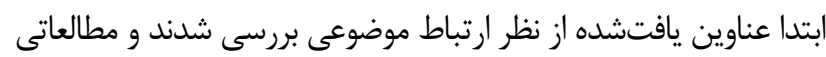

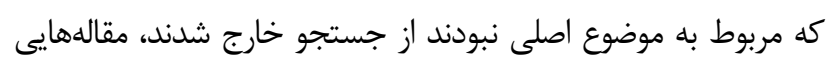
كه متن كامل آنها در دسترس نبود، انتشارات تكرارى و همجنين مقالههايى با نتايج مشابه نيز از مطالعه خارج شدند. علاوه بر موارد كفته

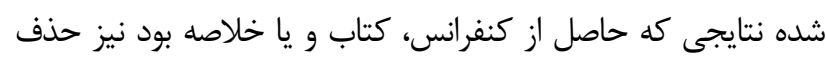
كَت. يس از غربالكرى مقالات يافتشده، مطالعات حاوى اطلاعات ذيل

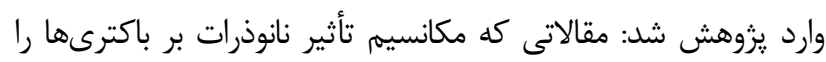

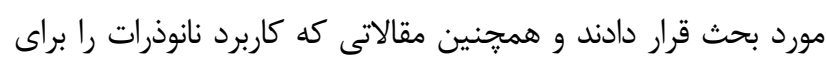

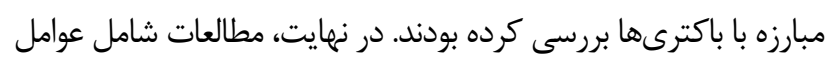

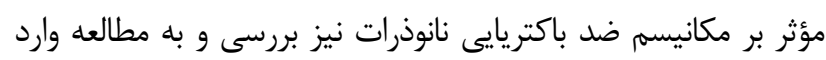

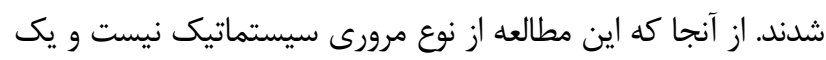
مطالعه مرورى روايتى است، اين تحقيق شامل تعداد مقالات كمى است.

بافتهها

\section{مكانيسمهاى مقاومت باكترى به آنتىبيوتيك}

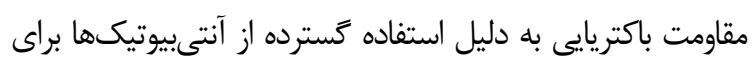

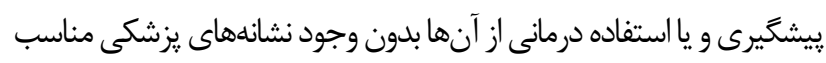
اتفاق مىافتد كه اين موضوع به يك مشكل جدى تبديل شده است. مقاومت

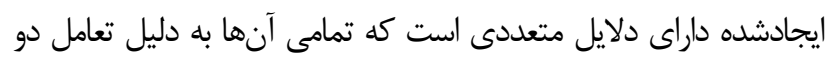
دسته عوامل درونى و بيرونى اتفاق مىافتند. عوامل بيرونى معمولاً شامل

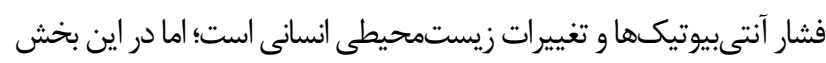
مكانيسم عوامل درونى از دو زاويه مختلف مورد بررسى قرار خواهد گرفتئ.

\section{بررسى مكانيسمهاى درونى ايجاد مقاومت از زاويه زنتيكى و در سطح برس ماسيسم}

مقاومت را مىتوان با توجه به منبع زنهاى مربوطه به مقاومت ذاتى و مقاومت اكتسابى تقسيهم نمود. مقاومت ذاتى در اثر جهش خودبهخود در زنهاى موجود يا عوامل بيرونى ايجاد مىشود، درحالى كه مقاومت اكتسابى از طريق زنهاى مقاومت دودئ

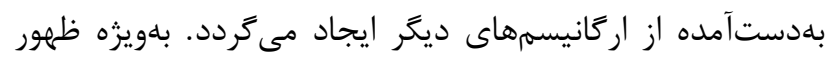
باكترىهاى مقاوم به جند دارو (MDR) نتيجه دستيابى به انواع مختلف زن هاى مقاومت دارويى توسط يك سلول باكتريايى است. بهطور كلى، مقاومت ذاتى، فرعى است و از اهميت كمترى برخوردار
مقاومت نسبت به نانوذرات (NPs) ندارند. زيرا نحوه عملكرد نانوذرات تماس مستقيم با ديواره سلولى باكترى است، بدون اينكه نيازى به نفوذ

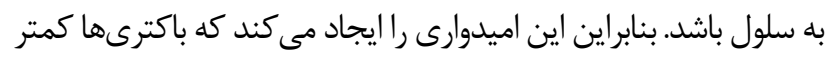
توانايى ايجاد مقاومت نسبت به نانوذرات را دارا باشند (F). در قرن بيست و يكم، فناورى نانو بهعنوان يكى از فناورىهاى مهرم و مؤثر بر علم در مقياس جهانى تبديلشده است. مهندسى نانو مواد يك فناورى توانمند است كه راههاى جديد تحقيق و توسعه را در برخى زمينهها ازجمله يزشكى، آرايشى، كشاورزى، علوم محيطى، علوم مواد، علوم زيست يزشكى، فناورى اطلاعات و مواد غذايى بازكرده است

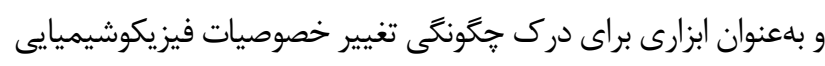

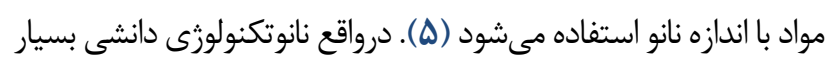
كاربردى است كه طيف وسيعى از علوم را شامل مى شود و كشورهاى

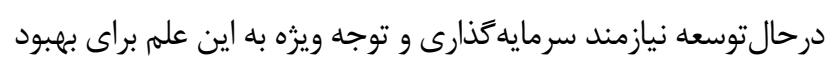
وضعيت در حوزههاى بهداشت و درمان، آب، انرزى و محيطزيست هستند (Y,V). نانو مواد به ذراتى كفته مىشود كه حداقل يك بعد آنها

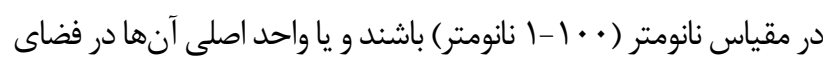
سلبعدى در اين محدوده قرار گيرد. نانوذرات بهطور وسيع الطيف در برابر هر دو گروه از باكترىهاى گرممثبت و گرممنفى تأثيرات خود را رانشان

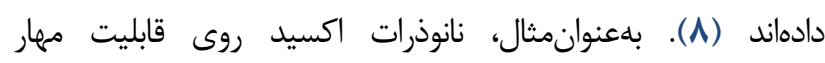

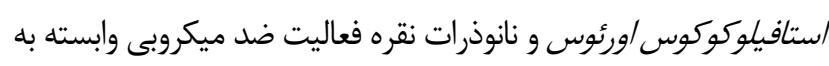
غلظت در برابر /شرشيا كلى و سودوموناس ائروزينوزا را نشان مى دهنيد. با اينحال، درحالى كه انواع مختلف نانوذرات اغلب اثرات متفاوتى دارند، مكانيسمهاى ضد باكتريايى آنها بهطور كامل مشخص نشده است (9). مكانيسمهاى ضد ميكروبى نانوذرات كه تاكنون يذيرفته شدهاند،

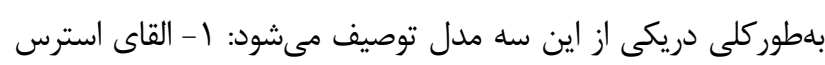

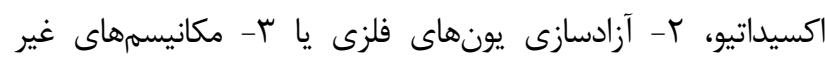
اكسيداتيو (•(). در فناورى نانو جشماندازهاى نوينى براى توسعه

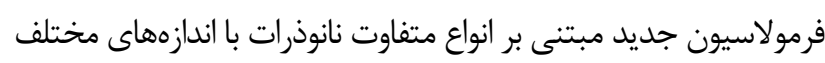
و شكلها و خصوصيات ضد ميكروبى برجسته وجود دارد. نانوذرات

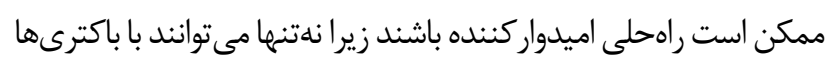
بجنگند بلكه مىتوانند بلعنوان حامل آنتىبيوتيكها و تركيبات ضد ميكروبى طبيعى نيز عمل كنند (1). اين مطالعه بر مكانيسمهاى مقاومت باكترى و فعاليت ضد باكتريايى نانوذرات تمركز دارد زيرا بررسى لئى مكانيسمهاى ضد باكتريايى اين ذرات براى توليد مواد ضد ميكروبى في مؤثرتر بسيار مرهم است.

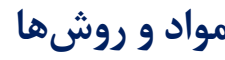

براى يافتن مستندات مرتبط با موضوع مورد بحث مقالات به زبان انغليسى و از يايگاه دادههاى الكترونيكى بهداشت و يزشكى استفاده شد. 
خواص جديدى مىشود، ازجمله اين خواص تعامل بيشتر با سلولها

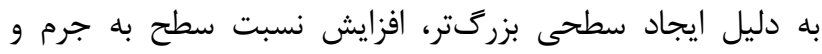

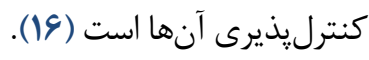

مبارزه عليه ميكروبها با استفاده از جندين مكانيسم

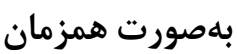

مكانيسم ضد ميكروبى آنتىبيوتيكهاى سنتى معمولاً نسبتاً ساده است كه تا حدودى دليلى بر مقاومت باكتريايى ثديدار شده استئ.

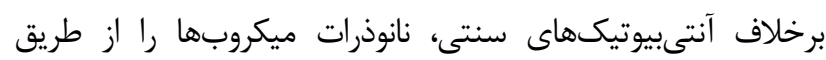
مكانيسمهاى متعدد كه همزمان فعال هستند، مورد حمله قرار مى دهند.

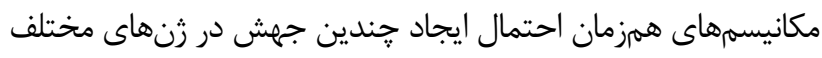

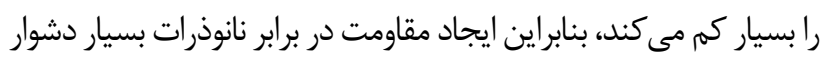

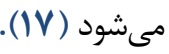

\section{ناثير نانوذرات بر عملكرد سيستم ايمنى}

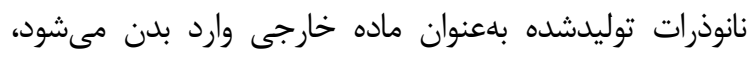

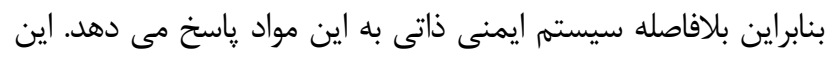

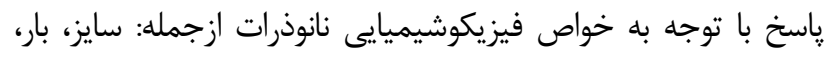

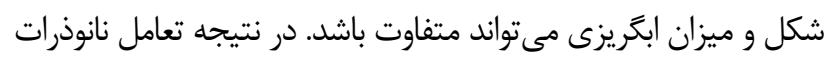

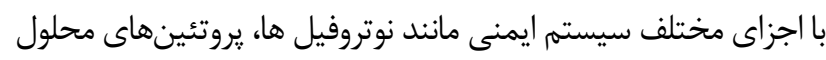

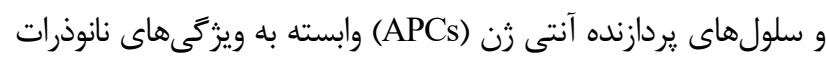

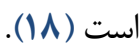

يكى ديكر از موارد تحريك سيستم ايمنى توسط نانوذرات، ايجاد

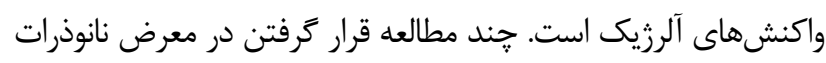
را با واكنشهاى آلرزيك در حيوانات و انسان مرتبط كرده است الت

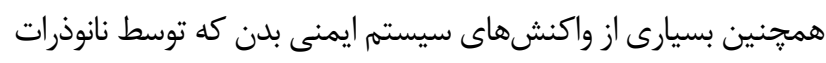

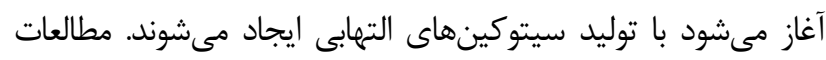
متعددى القاى سيتوكين را با انواع مختلف نانومواد (كلوئيدهاى طان النا،

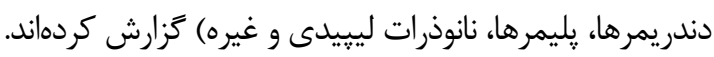

اطلاعات درباره تأثيرات مختلف نانوذرات بر سلولهاى سيستم

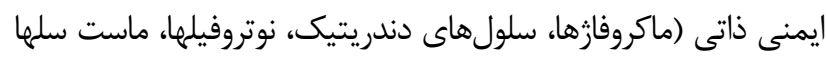

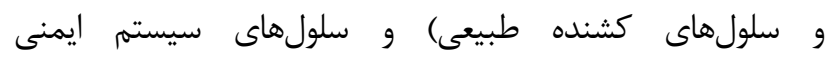

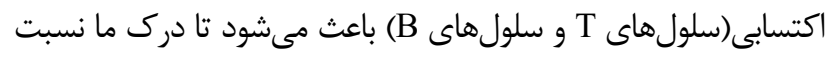

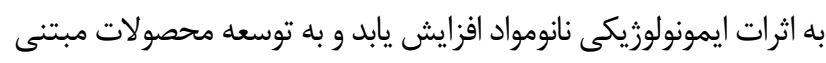
بر نانوذرات كمك مى كند (19). سلول هاى سيستم ايمنى ذاتى مانند

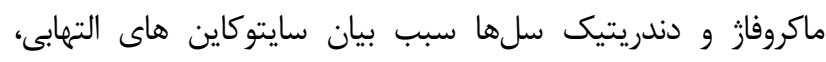

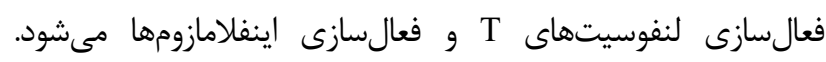

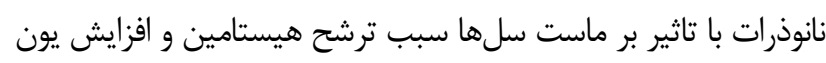

است .(Y) سه راه كه ازين طريق مقاومت مابين باكترىها منتقل

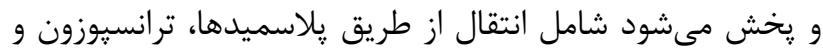

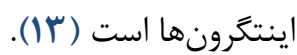

بررسى مكانيسمهاى درونى ايجاد مقاومت از زاويه بيوشيمى و در سطح يروتئين

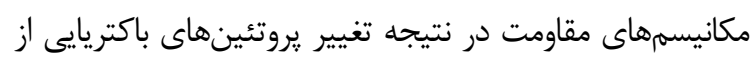

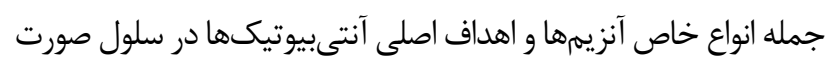

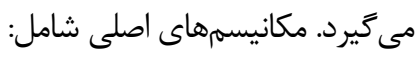
1-تغيير در هدف

$$
\text { r-غيرفعال كردن آنزيمها يا توليد آنزيمهاى غيرفعال }
$$
ب- استفاده از سيستمهاى يمب افلاكس فعال

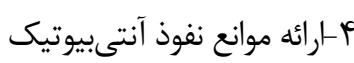
ه-تشكيل بيوفيلمها ع-از طريق كاهش و يا از بين بردن يروتئينهاى خاص مانند

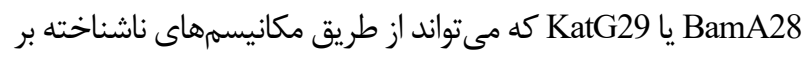

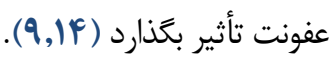

برخى از باكترىها مقاومت ضد ميكروبى را تنها از طريق

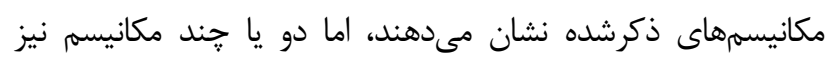
مى توانند در يك باكترى باهم تركيب شوند و اتفاق افتند، ازجمله:

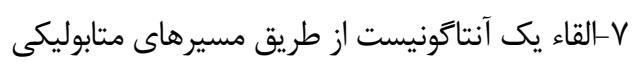
1-1فزايش توليد يك مهاركننده رقابتى با خنثى كردن آنتىبيوتيك.

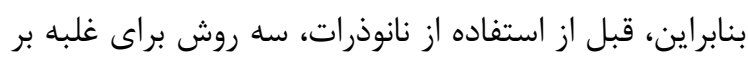

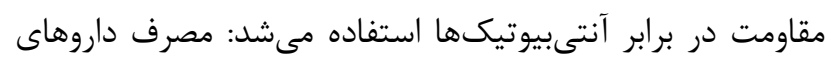

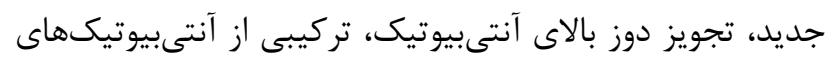

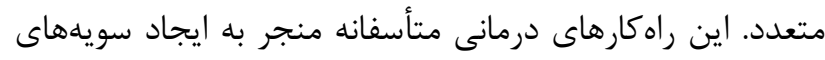

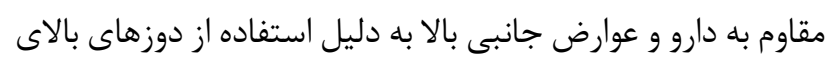

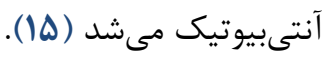

\section{دلايل استفاده از نانوذرات در درمان عفونتهاى باكتريايى}

\section{ويزگى هاى منحصر به فرد نانوذرات در مبارزه با باكترىها}

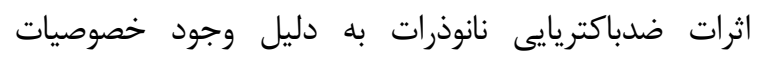

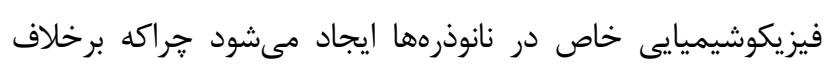

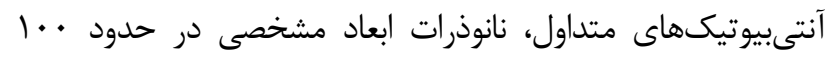

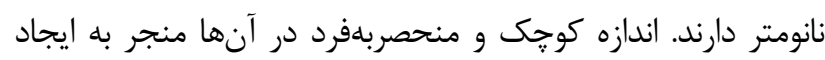




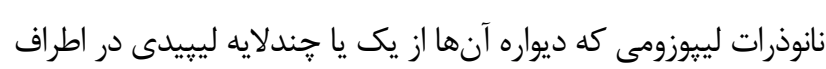

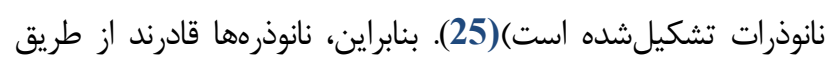
اندوسيتوز به سلولهاى ميزبان واردشده و دارو را آزاد نمايند.

\section{r- حفاظت نانوذرات از دارو: ناقلين دارو از جنس نانوذرات}

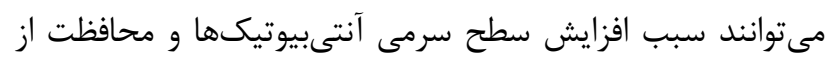

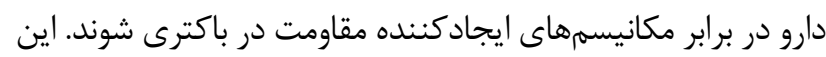

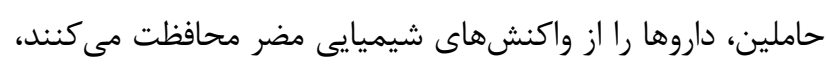

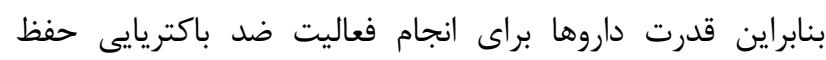

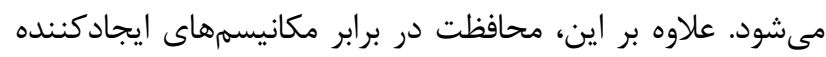

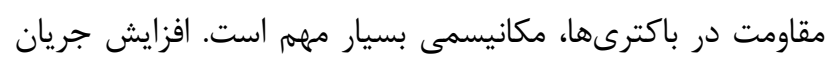

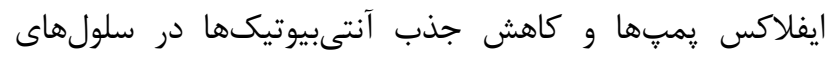

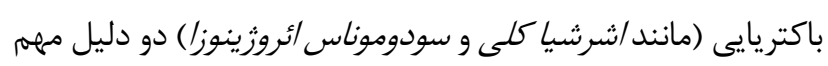

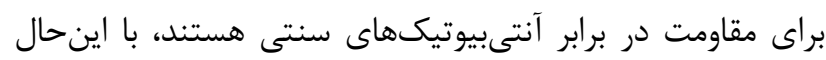

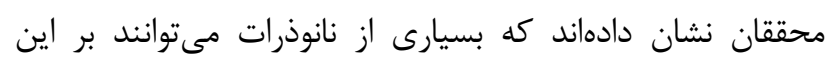

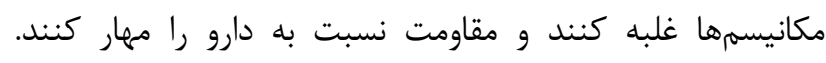

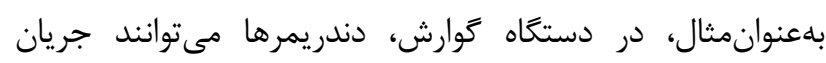

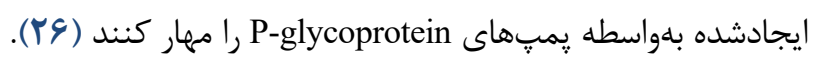

ץ- دقت در هدف قرار دادن عفونت: حاملين دارو از جنس نانوذرات مىتوانند در هدف قرار دادن محل عفونت توسط آنتىبيوتيكها

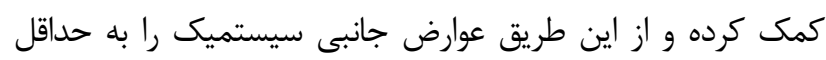

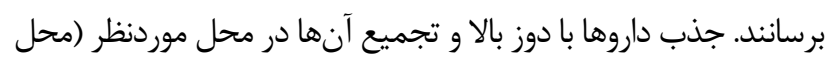

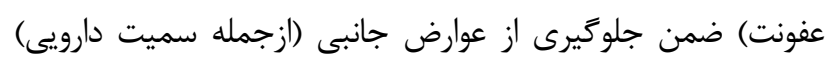

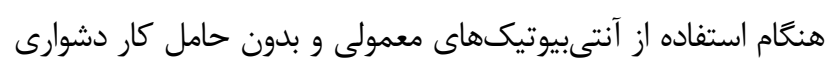

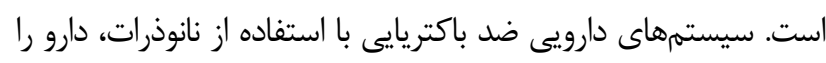

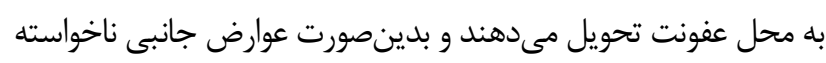

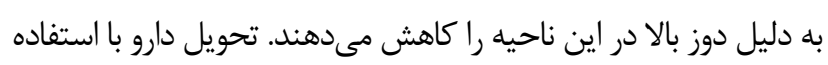

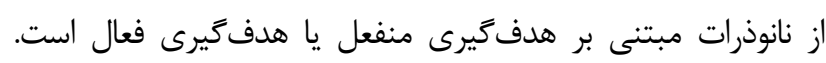

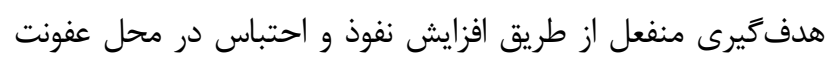

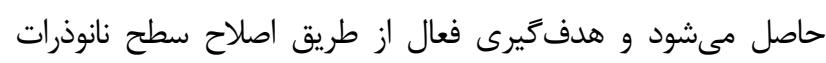

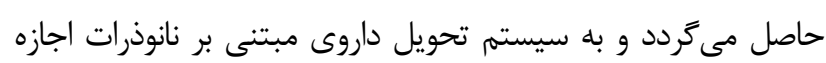

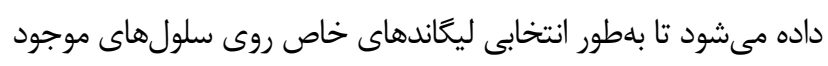
در محل عفونت را بشناسند. هدف

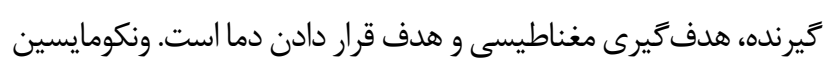

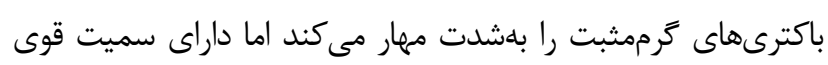

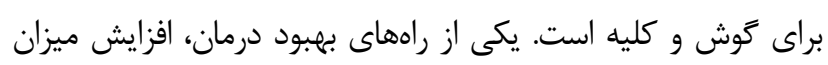

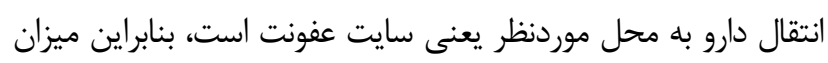

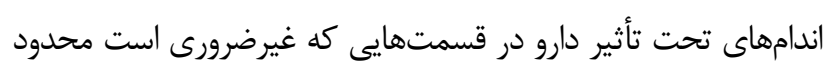

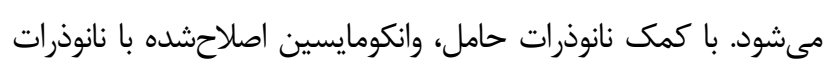

كلسيم سيتوزولى مىشوند. همجنين نانوذرات قادرند سلولهاى

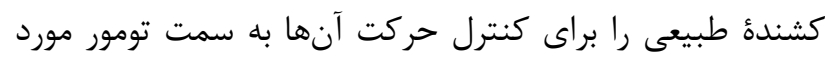

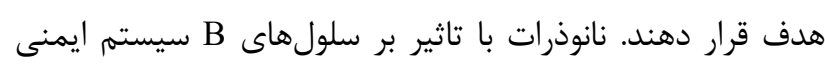

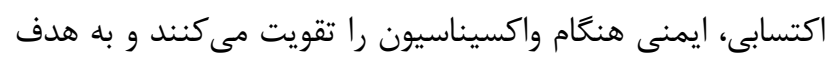

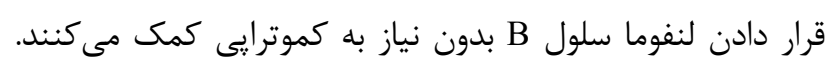

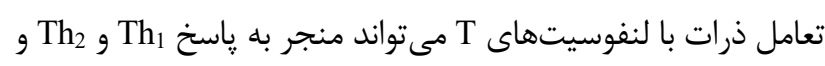

همجنين توليد سايتوكاين مىشود (19).

براساس واسخهاى ايمنى بدن نسبت به نانوذرات، اين مواد

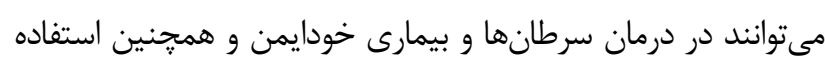
بلعنوان واكسن كاربرد داشته باشند (•r).

\section{فعاليت نانوذرات بهعنوان ناقل}

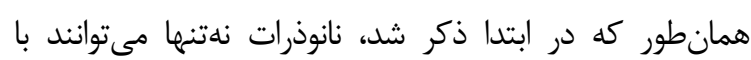
ميكروبها و مكانيسم مقاومت در باكترى مبارزه كنند، بلكه مى متوانند

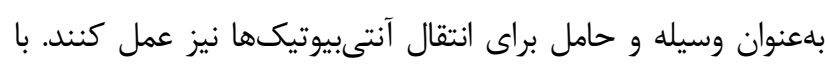

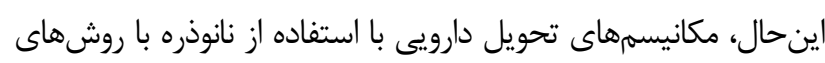

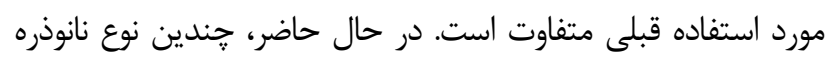

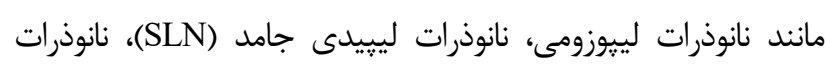

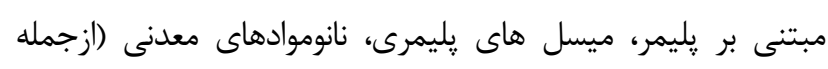

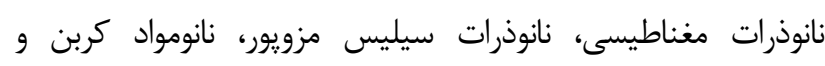

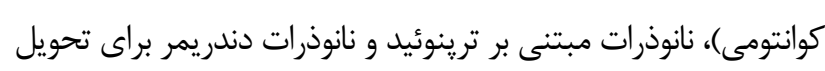

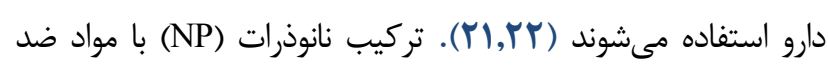

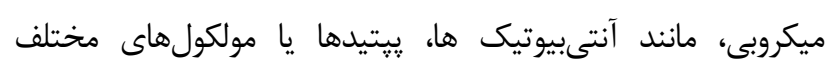

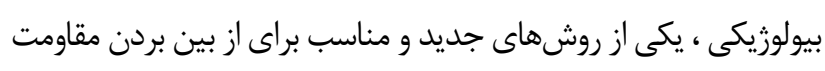

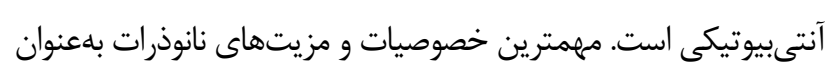
حامل آنتىبيوتيكها، در مقايسه با سيستمهاى قبلى فبلى در ادامه مورد بحث

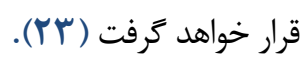

ا - اندازه كوجك نانوذرات. نانوذرات سايز فوقالعاده كوجكى إنى

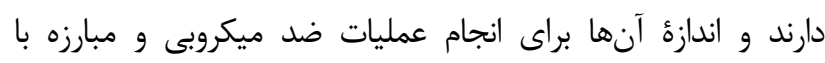

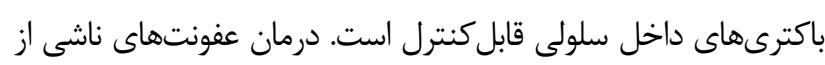

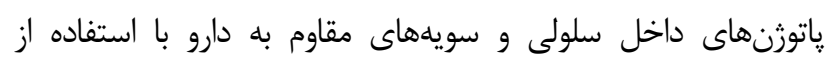

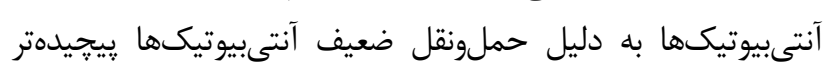

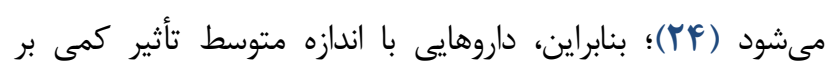

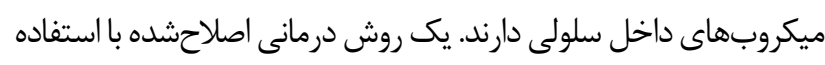

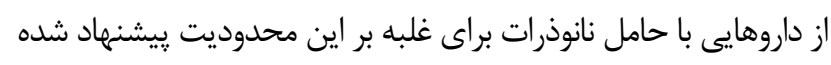

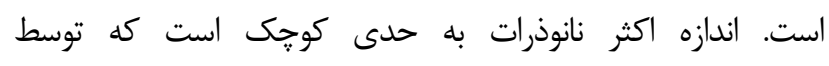

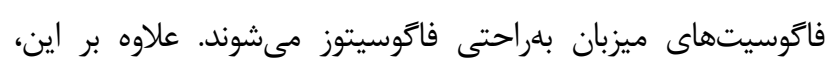
ساختار بسيارى از انواع نانوذرات براى حمل داروها مناسب است است (مانند 
راندمان بالاتر مى گردد. از طرف ديخر، مىتوان از دو يا جند نوع نانوذره

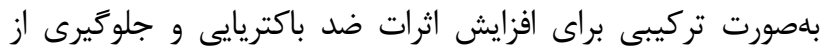

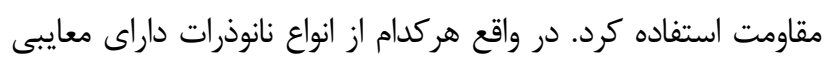

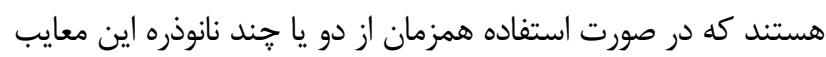

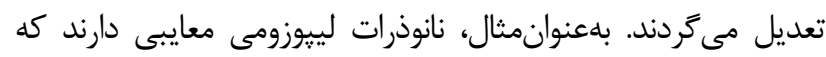

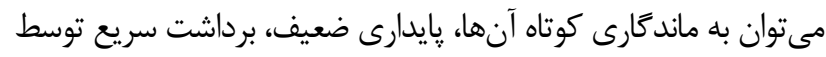

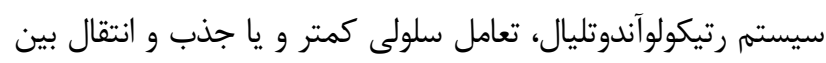
غشايى كندتر اشاره كرد. همجنين نانوذرات ليييدى جامد (SLN)

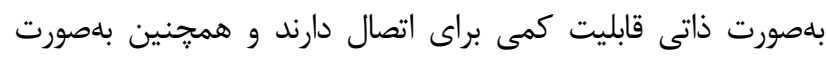

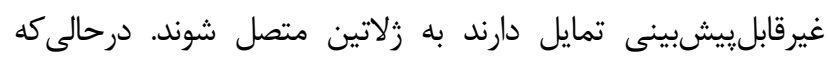

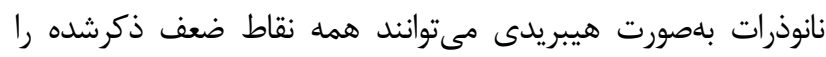

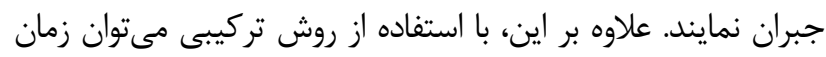

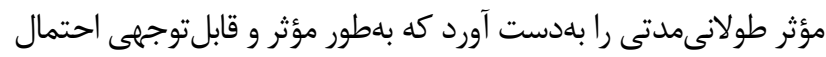

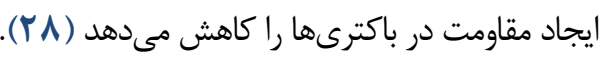

\section{مشكلات استفاده از نانوذرات در درمان عفونتهاى ميكروبى}

\section{ايجاد مقاومت نسبت به نانوذرات}

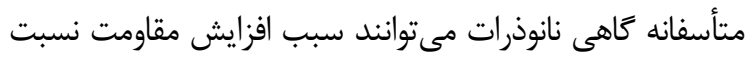

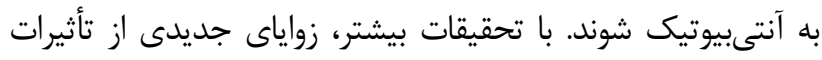
نانوذرات بر باكترىها مشخص شده است. درحالى كه بيشتر مطالعات

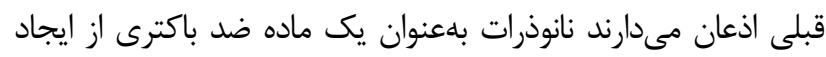

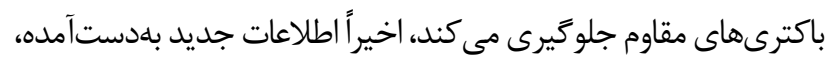

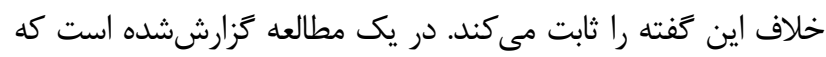

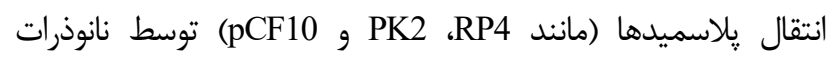

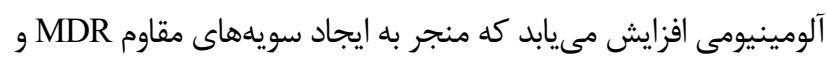

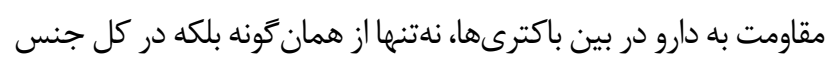

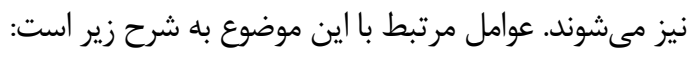
l . آسيب به غشاى سلول باكتريايى ناشى از استرس اكسيداتيو و به

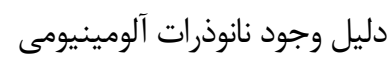

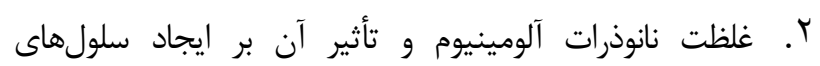
جفت r. محيط مناسب ازجمله دما و pH كه در انتقال از طريق آب تأثير دارد

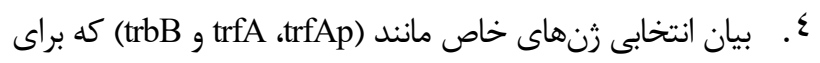
انتقال و تكثير پيلاسميدهاى RP4 مهرم هستند.

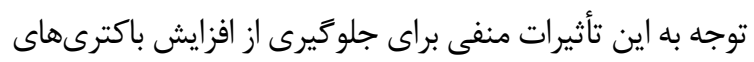

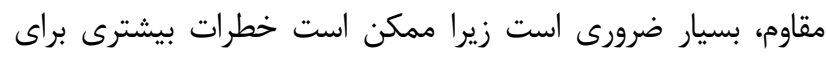
سلامت عمومى و محيطزيست ايجاد كند (•r).
سيليس مزويور طراحى شد و اين نانوذرات امكانى را فراهم كردهاند تا

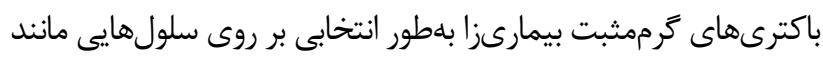

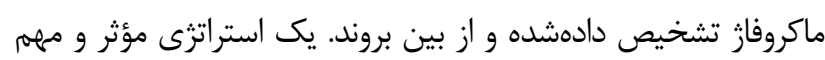

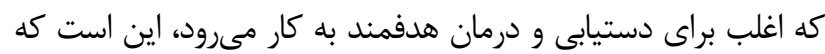

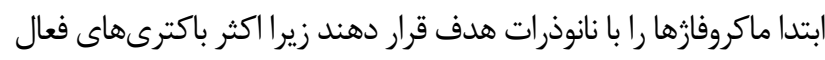

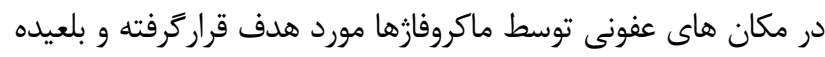

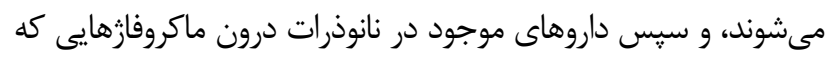

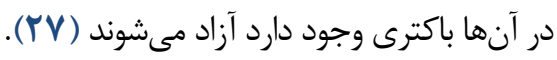

\section{ץ- قابليت كنترل رهاسازى دارو: با استفاده از نانوذرات} بلمعنوان حامل مىتوان آزادسازى آنتىبيوتيك را كنترل نمود. با استفاده

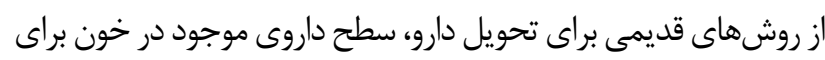

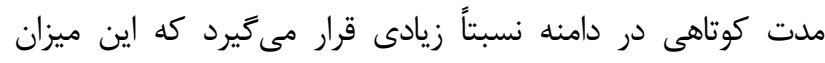

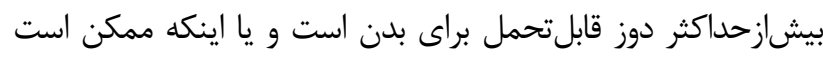

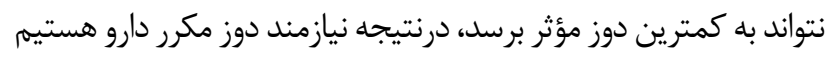

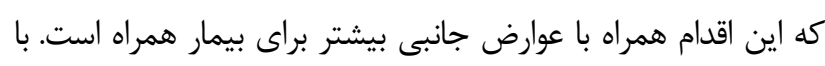

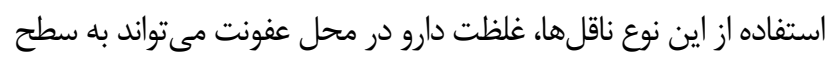

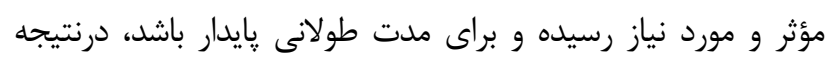

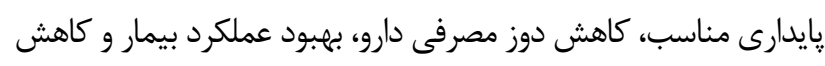

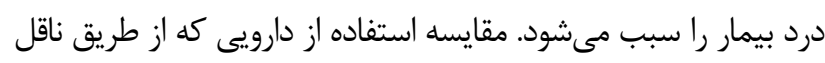

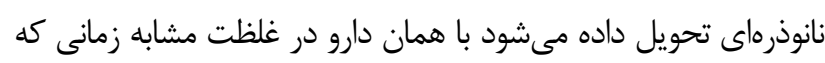

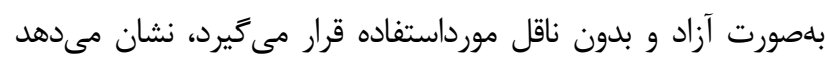

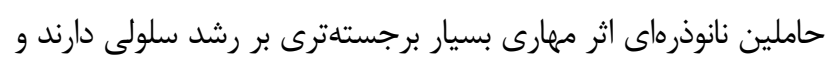

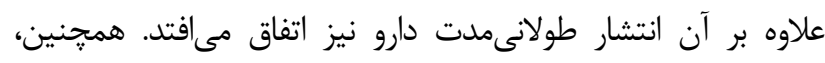

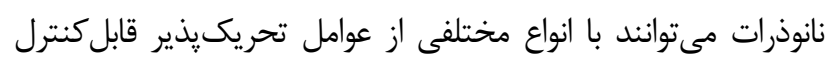

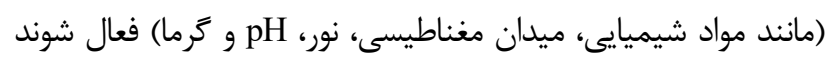

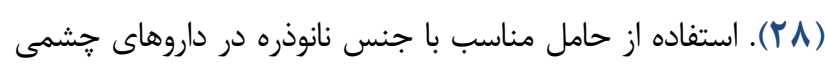

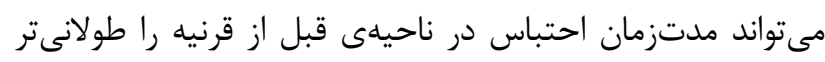

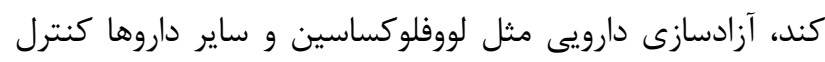

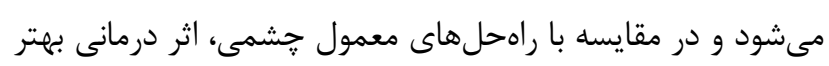

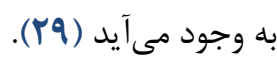

\section{ه- تركيب جند دارو: نانوذرات حامل قابليت تركيب و انتقال}

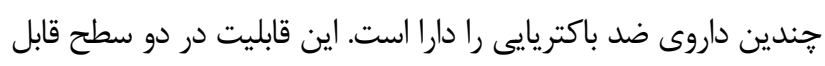

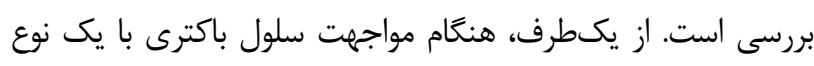

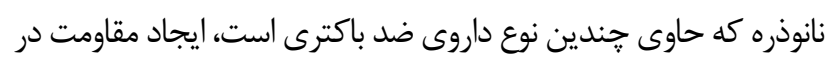

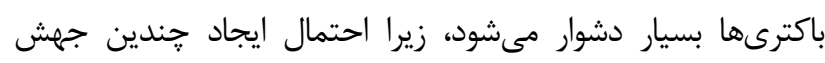

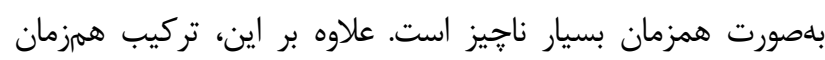

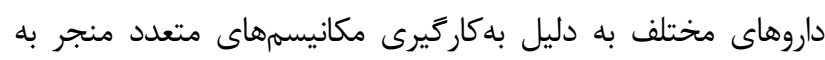


دارند. هزينه هاى مربوط به توليد و استفاده از اين نانوذرات بيشتر از

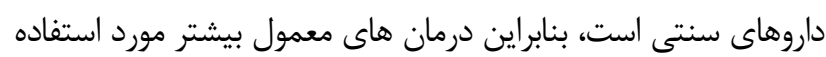

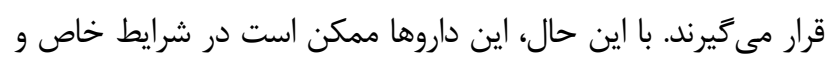

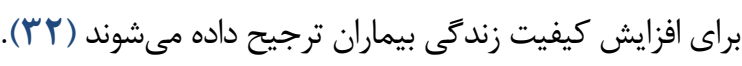

نمونهاى براى لييوزوم هاى ضد ميكروبى كه تحت آزمايشهاى

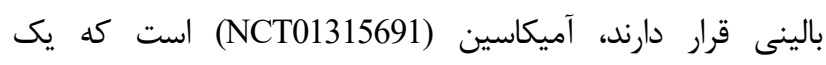
آنتىبيوتيك قوى آمينوكليكوزيدى است و براى داريكارين درمان باكترىهاى

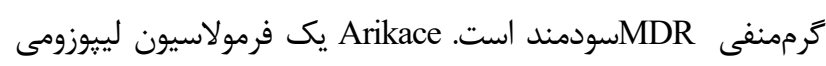
استنشاقى است كه آميكاسين متشكل از دييالميتويل-فسفاتيديل

كلولين (DPPC) و كلسترول را محصور مى كند. (Y (T)

\section{مكانيسمهاى ضد باكتريايى نانوذرات}

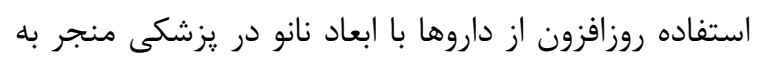

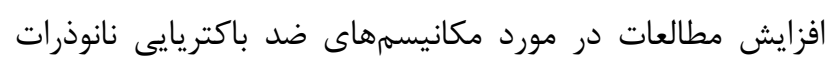

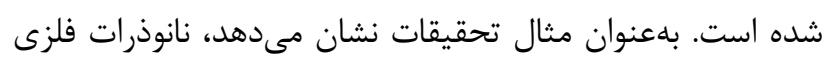

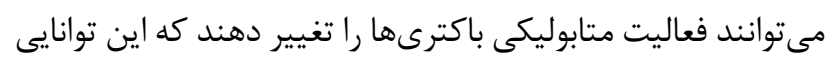

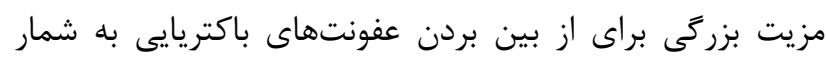

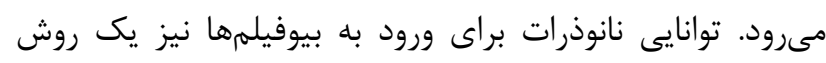

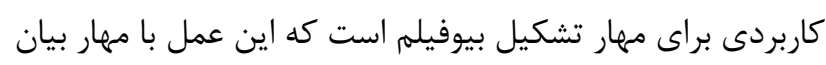

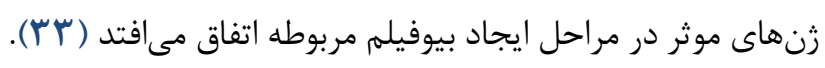

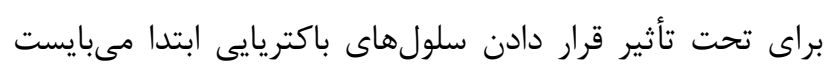

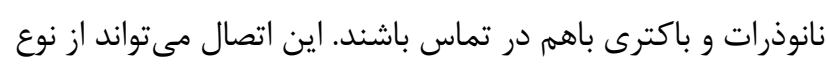

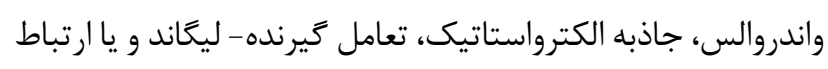

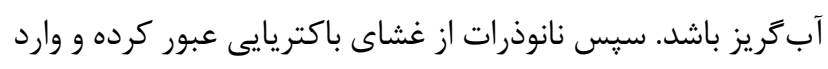
باكترى مىشوند، بر مسير متابوليك تداخل مى كنيند و همرجنين

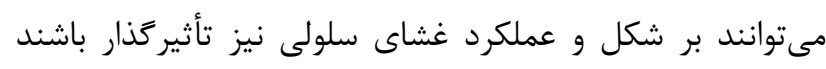
ماند (YF)

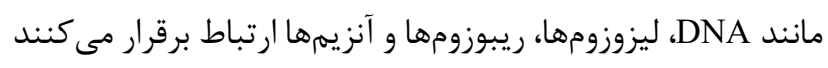

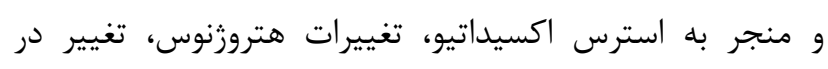

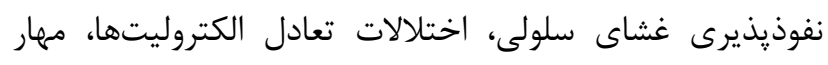

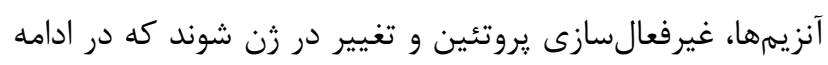

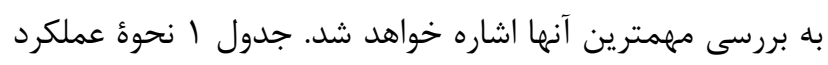

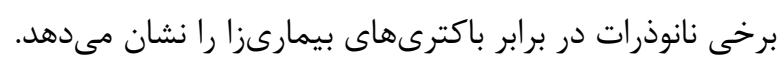

\section{سميت نانوذرات}

عوارض سمى موضعى و سيستميك و همجنين اثرات مضر بر نانودرات

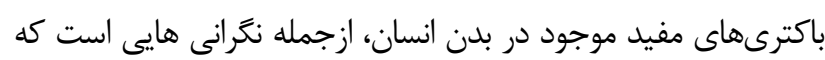

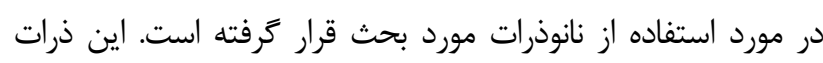

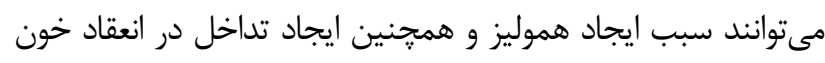

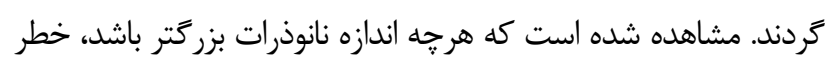

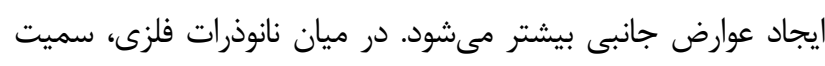

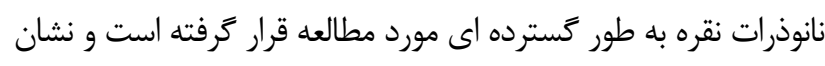

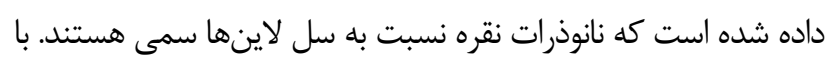

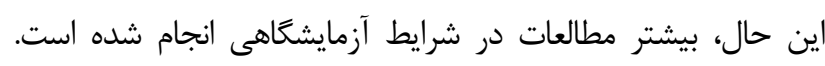

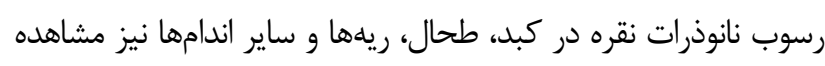

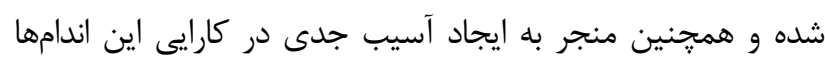

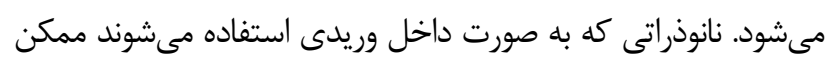

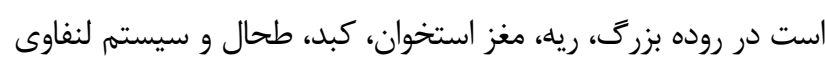

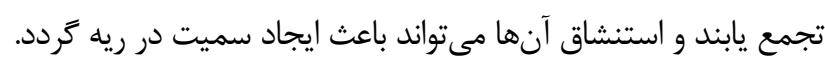

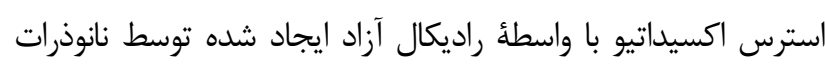

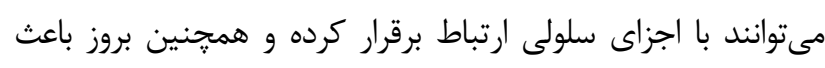

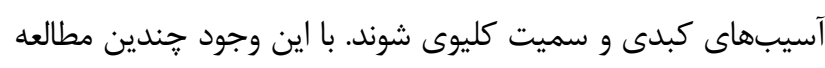

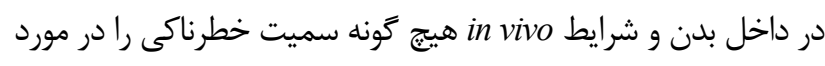

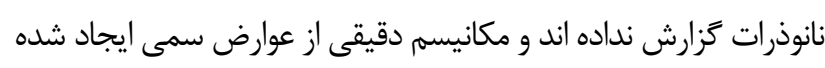

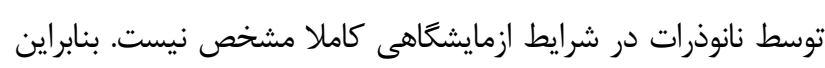

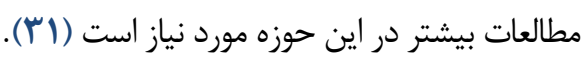

\section{كاربرد نانوذرات بهعنوان عوامل ضد باكتريايى}

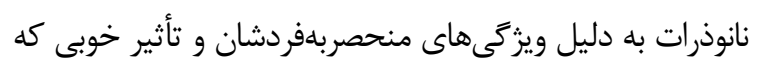

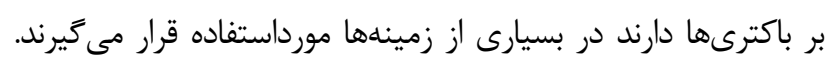

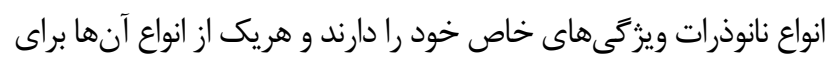
مكانهاى خاصى در بدن استفاده مىشوند. يارامترهايى شامل اندازه

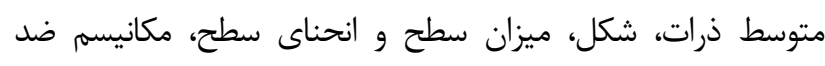

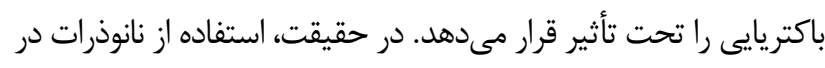

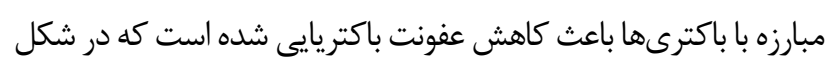

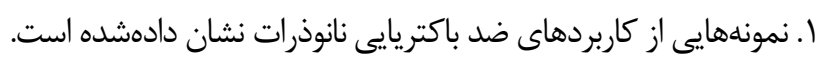

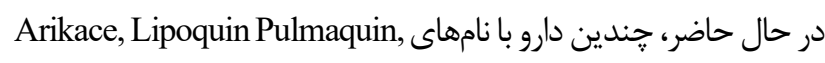
Silvasorb, MAT2501, QA-PEI عفونتهاى باكتريايى وجود دارد كه تحت آزمايش هاى بالينى قرار 


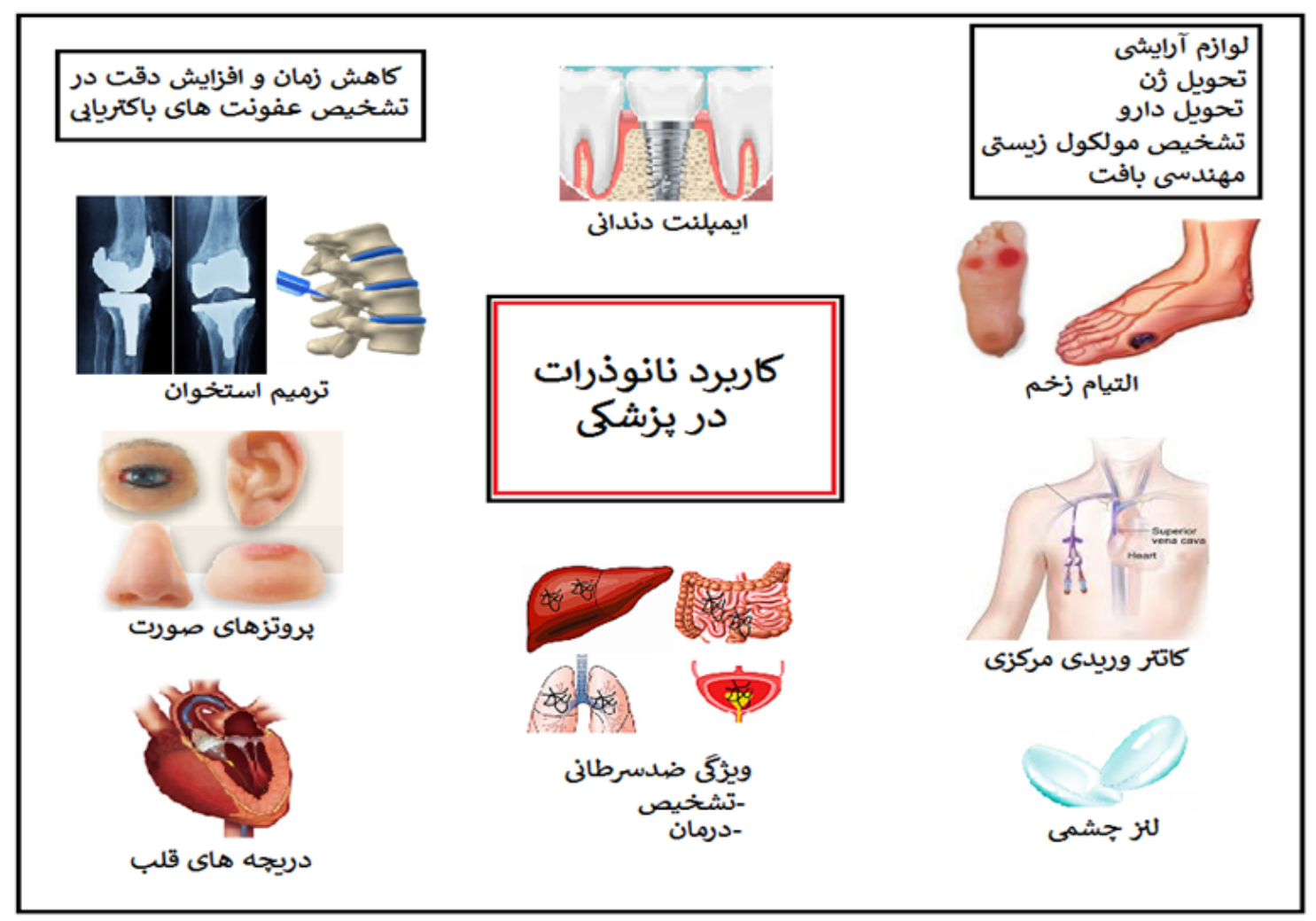

شكل ا. كاربرد نانو ذرات بهعنوان عوامل ضد باكتريايى (منبع: نكارندكًان)

اكسيرن در سلولهاى باكترى متعادل است. در مقابل، با توليد

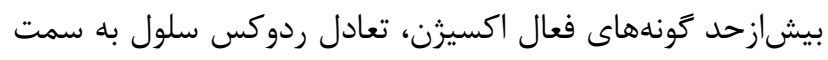

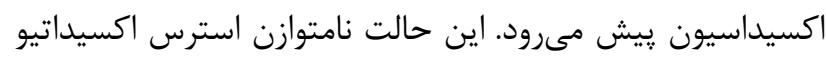

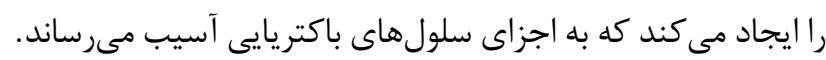

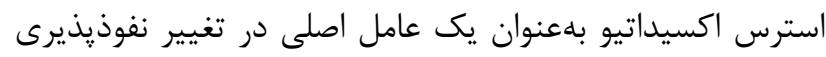

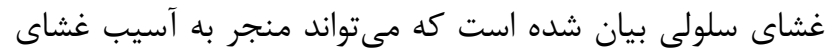

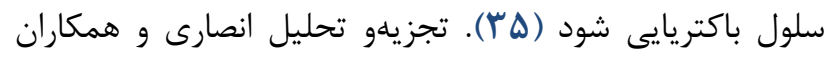
تأييد كرد نانوذرات

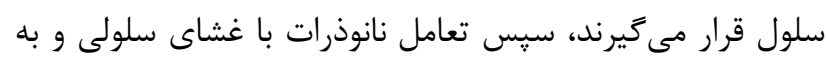

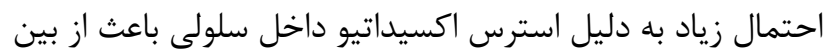

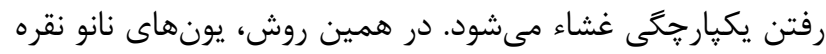

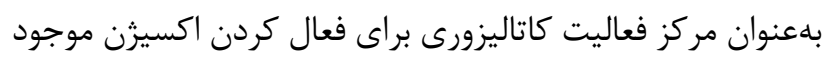

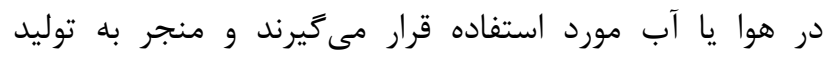

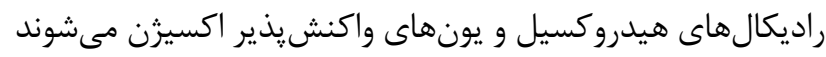

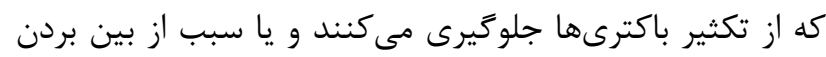

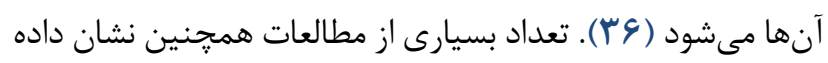

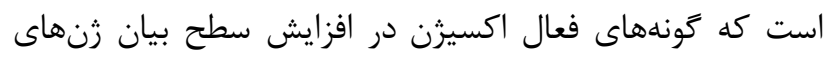
سازنده يروتئينهاى اكسيداتيو مؤثر هستند كه يك مكانيسم مهانم در آيويتوز سلول هاى باكترى است. علاوه بر اين، كونههاى فعال

\section{ا- عملكرد نانوذرات بواسطه استرس اكسيداتيو}

استرس اكسيداتيو ناشى از توليد گونههاى فعال اكسيزن

يك مكانيسم مهم ضد باكتريايى براى نانوذرات است.

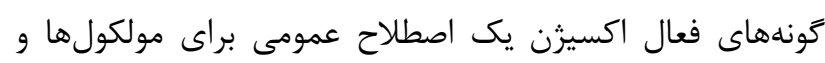

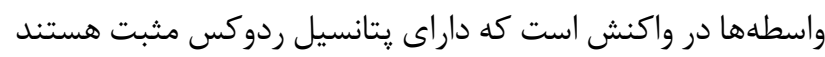

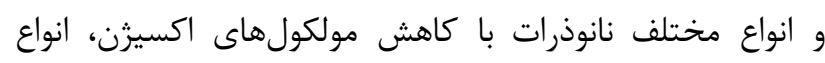

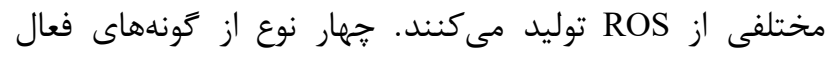

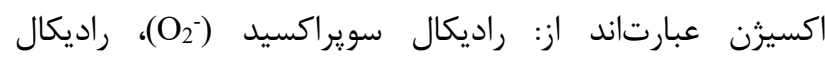

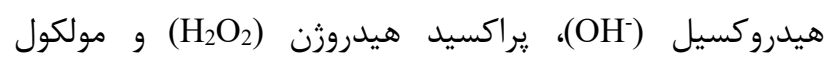
اكسيرن (O2) كه سطوح مختلفى از يويايى و فعاليت را نشان

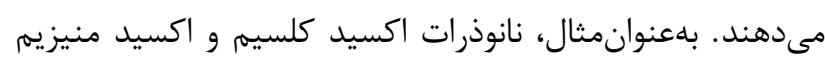

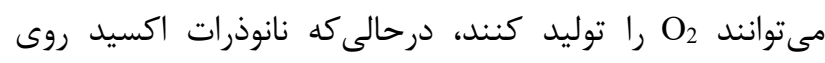

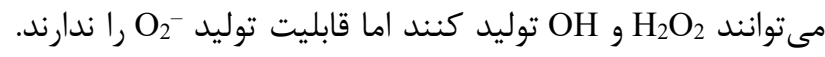

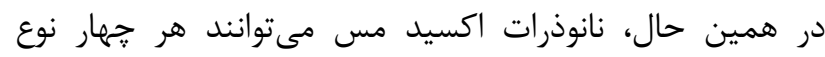

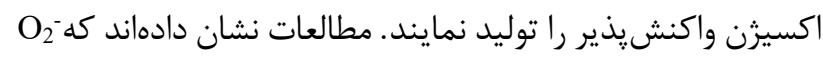
باعث بروز واكنشهاى استرسى كمترى مى شوند و و توسط آنتى اكسيدانهاى درونى مانند آنزيمهاى سويراكسيد و و كاتالاز خنثى مىشوند، درحالى كه OH و OH مئى

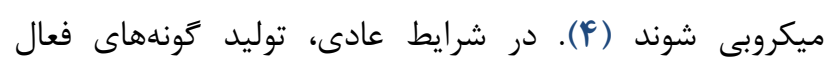


اين، يونهاى فلزات سنخين مىتوانند بلطور غير مستقيم بلعنوان حامل مواد ضد ميكروبى عمل كنند (FT).

\section{مكانيسم هاى نفوذ نانوذرات به درون باكترى}

انتشار: نانوذرات مىتوانند با استفاده از انتشار يا ديفيوزن كونههاى فعال اكسيرن را به باكترى انتقال دهند. در يك مطالعه،

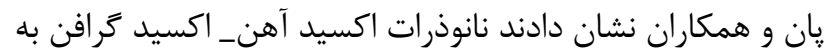
دليل توليد مقادير زياد راديكال هاى هيدروكسيل و انتشار به درون سلولهاى باكتريايى، مىتوانند باكترى /ستافيلوكوكوس /ورئوس مقاوم به متىسيلين (MRSA) را غيرفعال كرده و حداكثر فعاليت

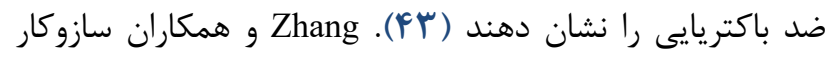
توليد گونههاى فعال اكسيرن توسط نانوذرات نقره، طلا، نيكل و وهند سيليكون را در سيستم آبى تحت تابش اشعه ماوراءبنفش (هQ

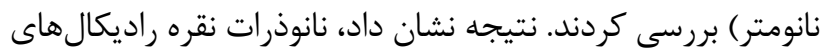

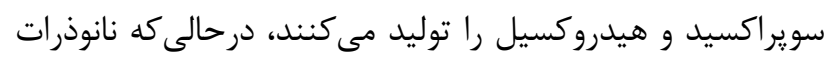

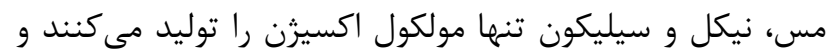

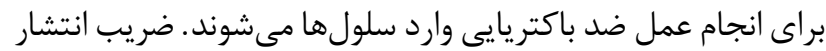

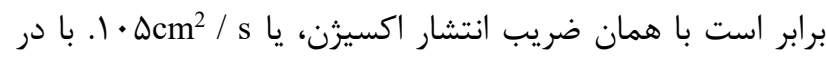

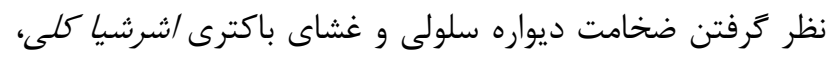

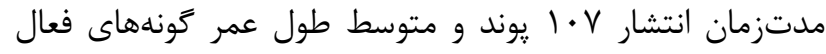

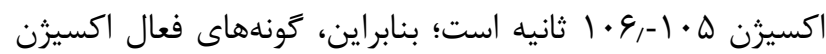

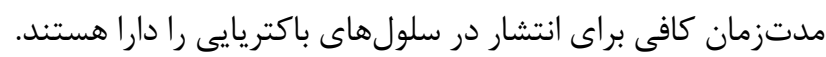

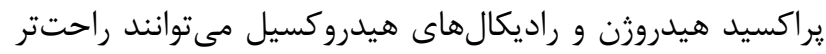
از راديكال سوير اكسيد به غشاى سلولى باكترى نفوذ كنند (FF). علاوه بر اطلاعات فوقالذكر، Mukha و همكاران نشان دادهاند،

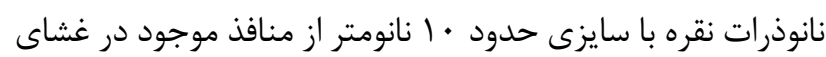
سلولى عبور كرده و به درون سلولهاى ميكروبى نفوذ مى يابند ؛

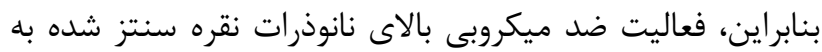

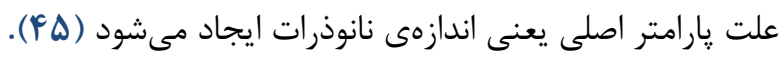
جذب: نانوذرات فلزى به محيط اطراف آزاد مىشوند و با

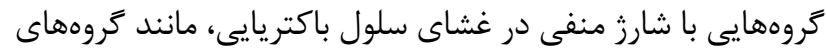

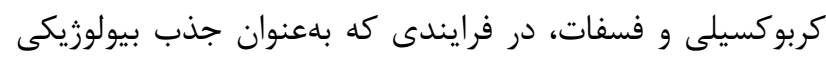

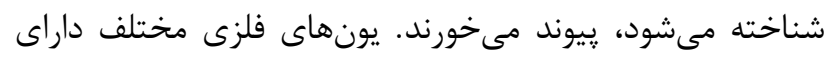

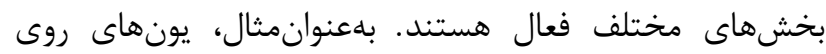

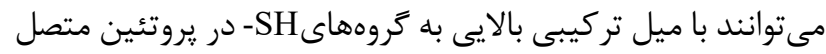

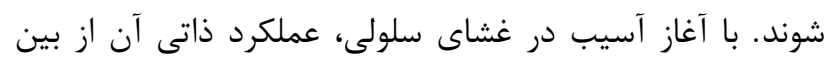

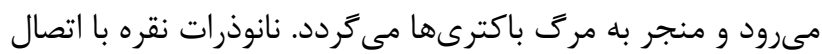
محكم به سطح غشاء سلولى جذب مىشوند و و منجر به به انعقاد

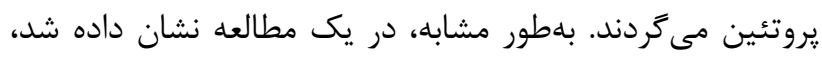

اكسيزن مىتوانند به بروتئينها حمله كرده و فعاليت برخى دهن

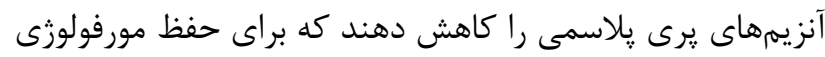

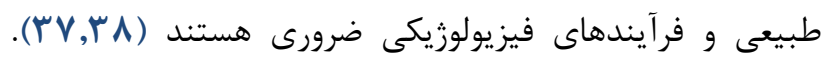
بهنوان نمونهاى ديكر، نانوذرات تحت اثر اشعه ماوراءبنفش (UV)

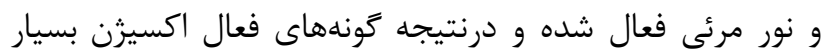

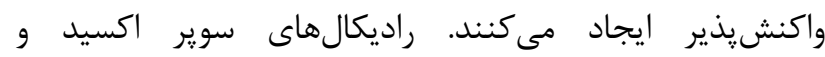
هيدروكسيل با بار منفى مىتوانند بر روى سطح سلول رئن حفظ شوند

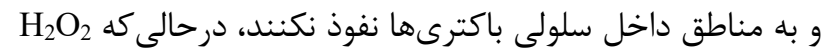
مىتواند از غشاى سلولى عبور كرده و به درون سلول باكترى راك راه

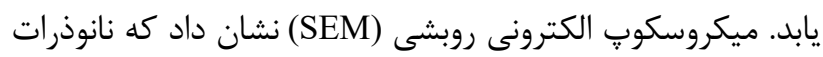

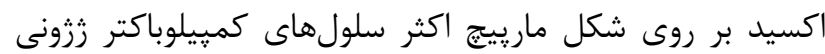

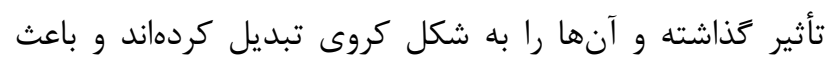

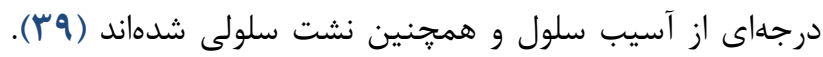

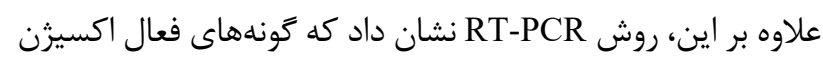
باعث افزايش سطح بيان دو زن استرس اكسيداتيو Kat A و رئ

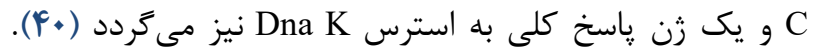

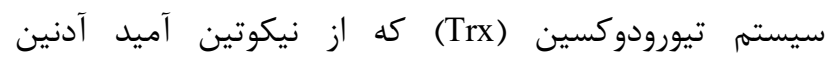

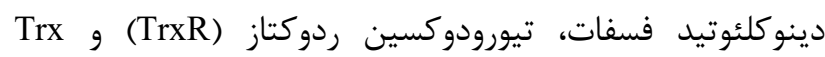
تشكيل شده است، يكى از مهمترين سيستمهاى ردوكتاز دى سولفيد است كه باكترىها عليه استرس اكسيداتيو مورد استفاده

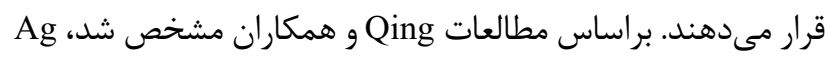

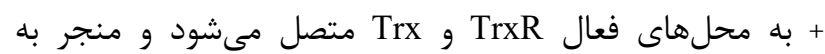
اليكومريزاسيون و اختلال عملكردى TrxR و TrxR مى تردد (Y) (F).

\section{r- عملكرد نانوذرات بواسطه يونهاى فلزى محلول}

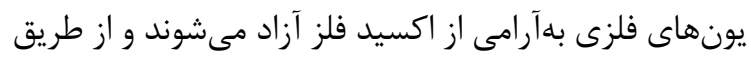
غشاى سلولى جذبشده و به دنبال آن تعامل مستقيم با كروههاى

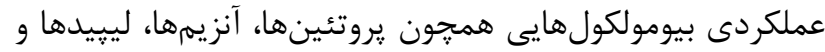

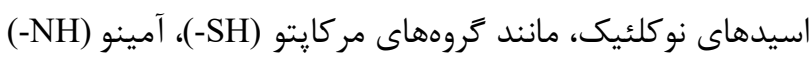

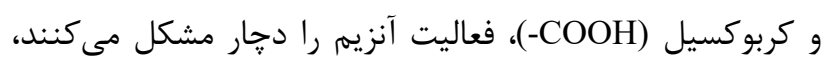

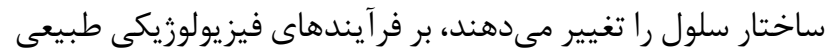

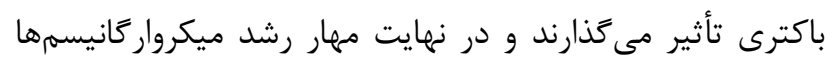

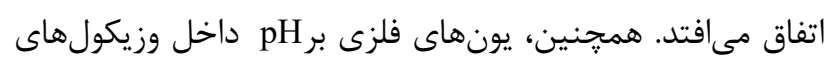
ليييدى نيز تاثير كذار هستند كه اين عمل آنها فعاليت ضد بد

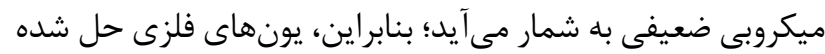

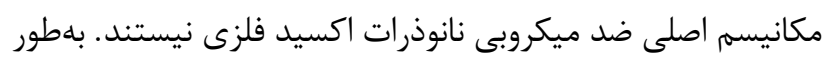

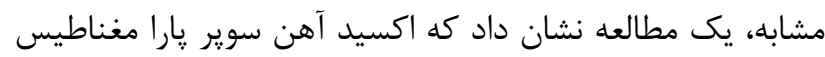

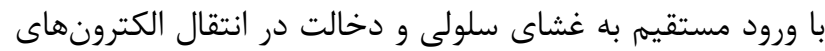

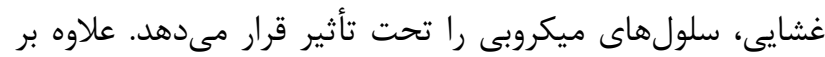


جريان يونها را در درون و خارج از غشاى سلول باكترى تنظيم

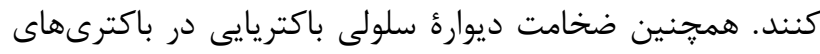

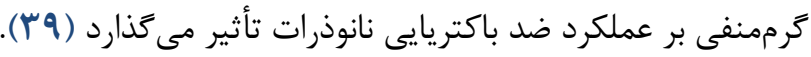
برخى محققان به همين ترتيب معتقدند كه ساختار باكترى ها مىتوانند بر فعاليت ضد ميكروبى نانوذرهها تأثير بكذارند.

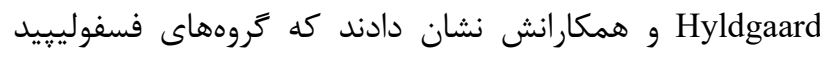

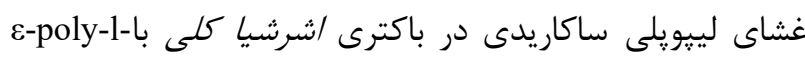

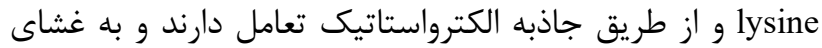
سلولى آسيب مىرسانند (F)). در يك مطالعه ديكر، همكارانش به بررسى فعاليت ضد باكتريايى نانو ديموندها در

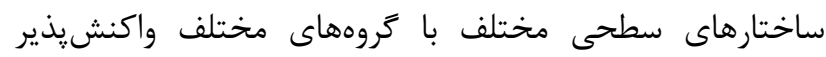
يرداختند و دريافتند كه اين نانومواد مىتوانند يبيوندهاى كووالانسى با يروتئين و مولكولهاى مجاور در ديواره سلولى ايجاد

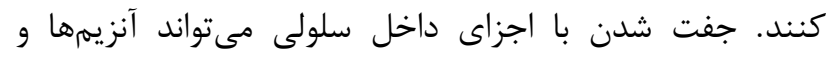
يروتئينهاى كليدى را مهار كرده و باعث اختلال در متابوليسم باكترى و در نهايت مرى سلولى شود. نانوديموندها براى انجام

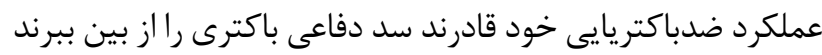
Foster و و همكاران تأييد كردند نانوذرات اكسيد تيتانيوم مىتوانند براى توليد گونههاى فعال اكسيزن به سطح سلولهاى

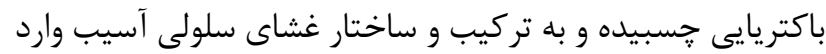

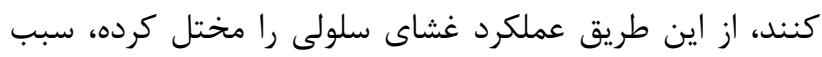

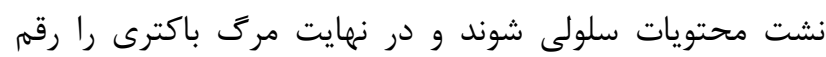

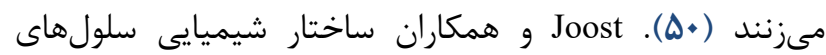

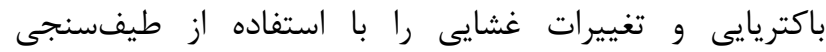

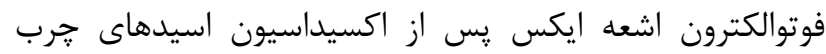

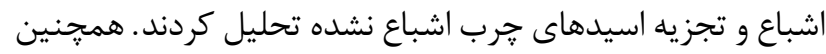
آنها ميزان (MDA) Malondialdehyde) را نيز تعيين كردند. نتايج

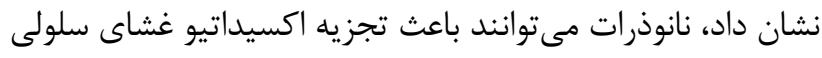
باكترى شوند. تماس مستقيم بين نانوذرات اكسيد تيتانيوم و سلول

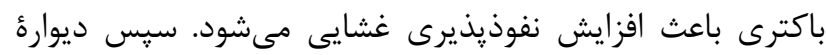

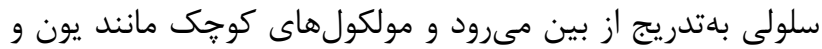

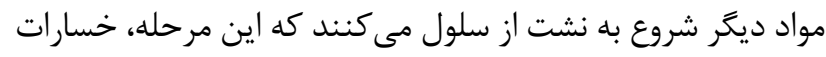

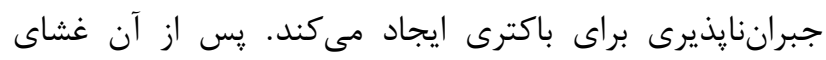

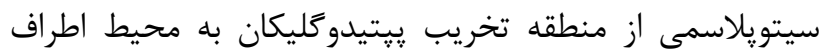

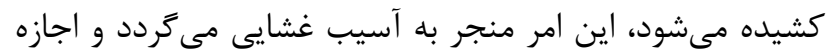

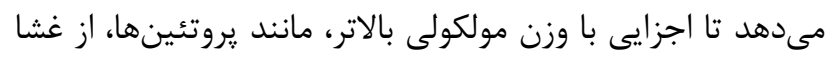
عبور كنند و تخريب سلول اتفاق مىافتد (اله).
بارهاى سطحى نانوذرات مس به ميزان قابلتوجهى در جذب

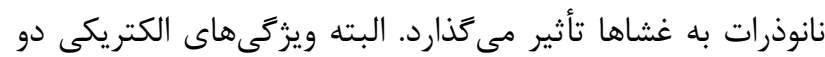

لايه نيز مهرم است (4).

\section{تاثير نانوذرات بر قسمت هاى متفاوت باكترى}

\section{ا - تعامل نانوذرات با غشاى سلولى و ديواره سلولى باكترى} ديوارهى سلولى و غشاء در باكترىها موانع دفاعى مهمى براى مقاومت نسبت به محيط خارجى هستند. بلويزه، ديواره سلولى باكترى نقش مهمى در حفظ شكل طبيعى باكترى دارد.

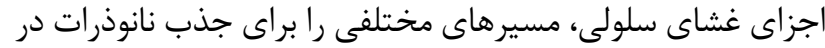
باكترىهاى كرممثبت و كرممنفى ايجاد مى كنند. لييويلى ساكاريد يك ساختار منحصربdفرد از ديواره سلولى باكترىهاى إنى

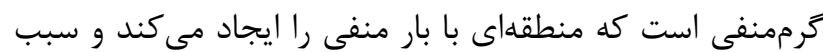
جذب نانوذرات مى گردد. در مقابل، اسيد تيكوئيك فقط در ديواره سلولى باكترىهاى كرممثبت بيان مىشود، بنابراين نانوذرات دردات درد

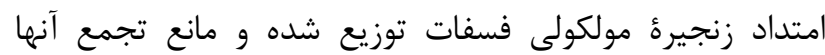

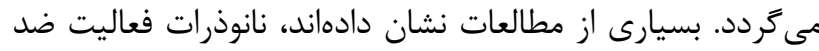

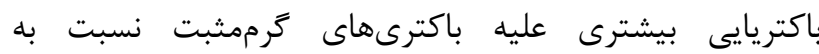

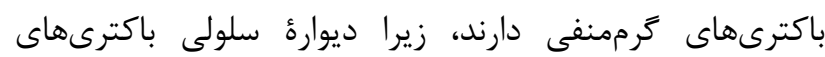

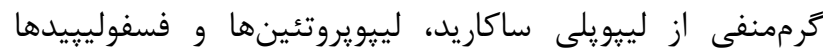
تشكيلشده است كه مانعى قابلنفوذ فقط براى عبرئ عبور

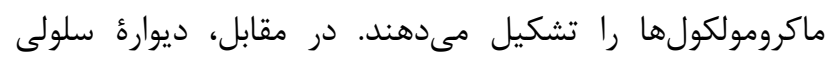

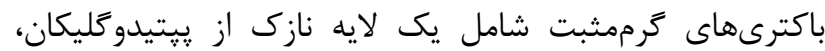

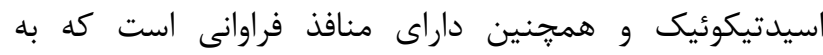

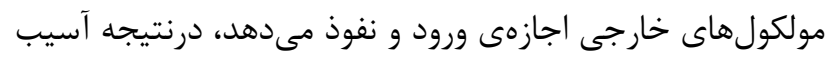

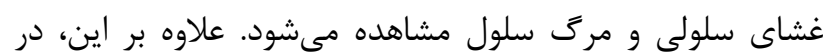

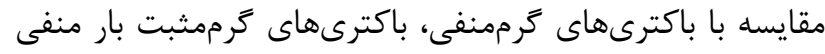

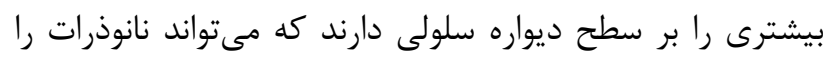

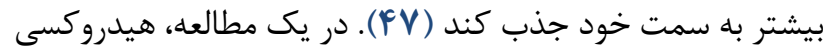

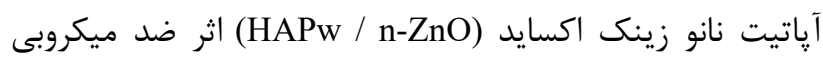

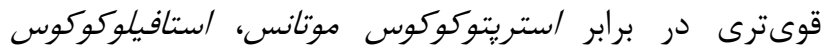
اورئوس و كانديدا البيكنس نسبت به باكترى /شرشيا كلى داشت.

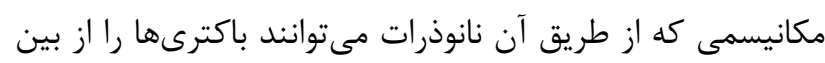
ببرند به اجزا و ساختار سلول باكترى بستخى دارد. اثر ضد ميكروبى ناتي اكسيد روى به اجزاى سلولى باكترى وابسته است كه ممكن است

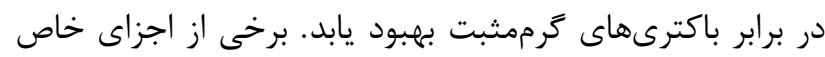

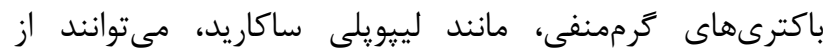
جسبندگى اكسيد روى به سد سلولى باكترى جلوكيرى كرده و 


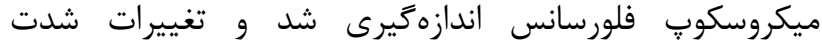
فلورسانس سيتو يلاسم هنگام تغيير يتانسيل غشاى سلولى مشاهده كرديد (W) مىتواند به يروتئينهاى موجود در غشاى سلولى متصل شود و

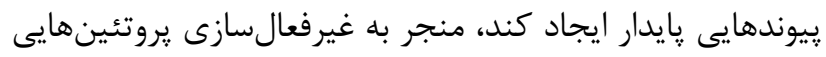

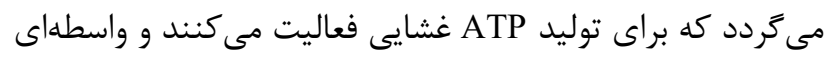
براى انتقال يونها را از طريق غشاى سلولى هستند (F)).
يكى از مهمترين كاركردهاى غشاى سلولى، فعاليت تنفسى باكترىها است. مطالعات كزارش دادهاند كه نانوذرات فعاليت تنفسى غشاى سلول باكتريايى را نيز مختل ميى كنند (52).

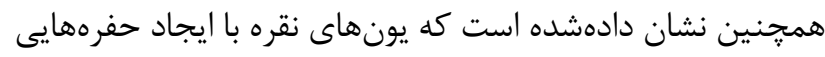
در ديواره سلولى، افزايش نفوذيذيرى غشاء و غيرفعال كردن زنجيره تنفسى، مانع از رشد/شرشيا كلى مى ديوند. علاوه بر اين، يتانسيل غشاى سلول باكتريايى نقش مهمى در روابط سلولى ايفا مى كند

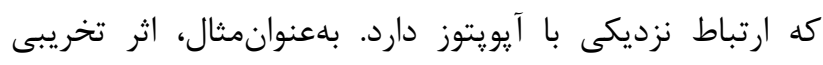

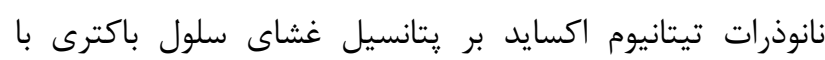

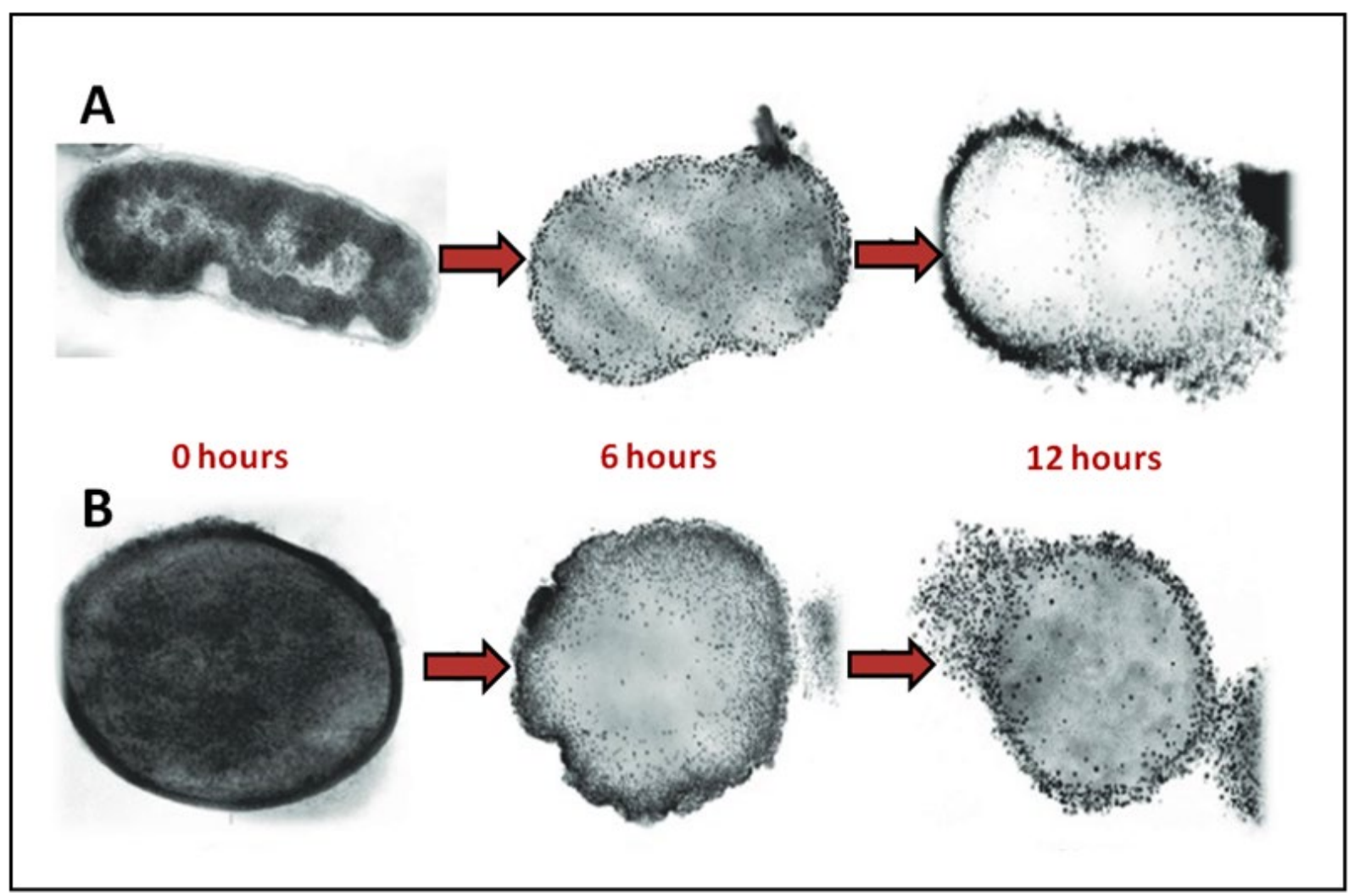

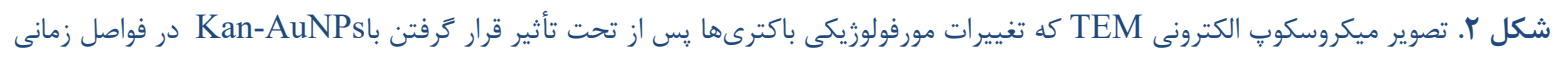

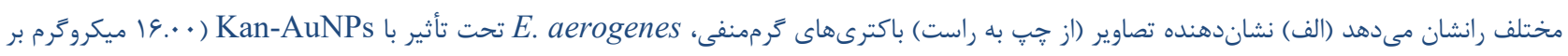

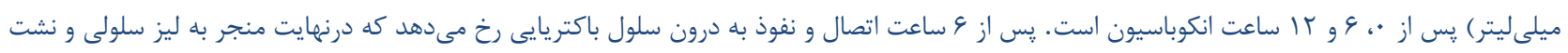

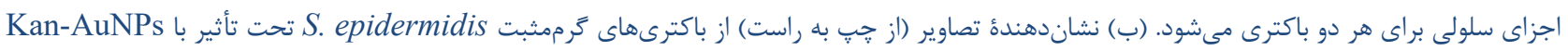

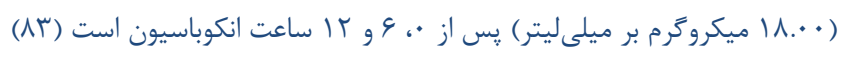

به سلول، تجزيه و تحليل بيوانفورماتيكى يروتئوميك نشان داده شد،

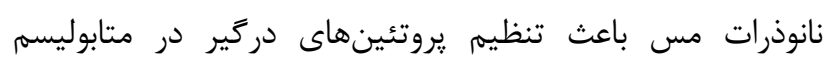

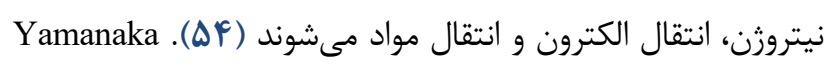

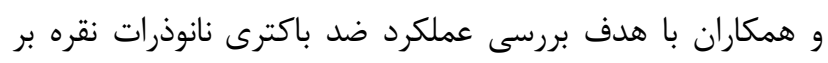

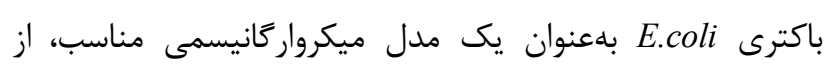

r- مهار سنتز يروتئين و DNA در باكترى

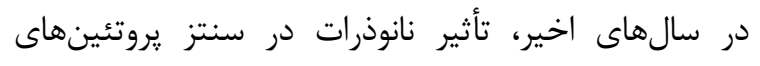
باكتريايى بسيار مورد توجه محققان قرار كرفته است. Su و و همكاران

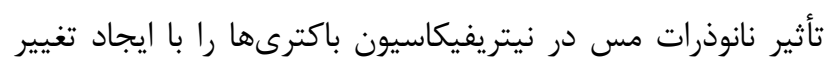

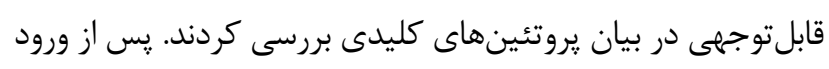


باكتريايى باعث آسيب به غشاى سلول باكترى و ايجاد استرس

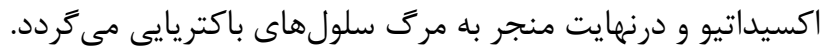

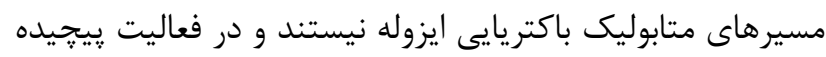

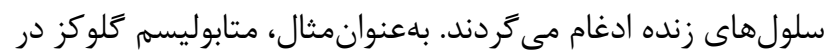
باكترى استريتوكوكوس موتانس مكانيسم مهمى است كه باعث

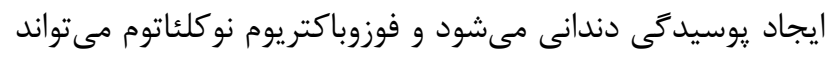
از متابوليتهاى اسيدهاى آمينه مانند اسيد بوتيريك استفاده كند

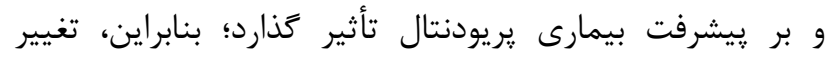

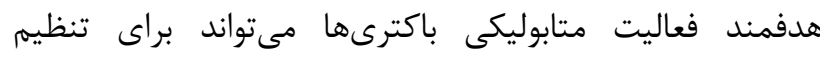

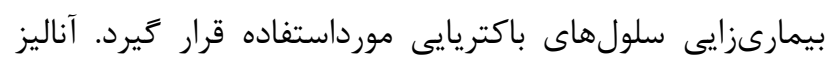
طيفسنجى مايع رنكى نشان داد كه نانوذرات اكسيد منيزيم

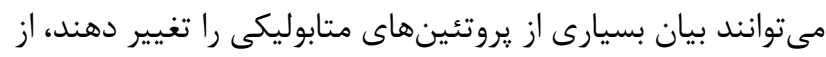

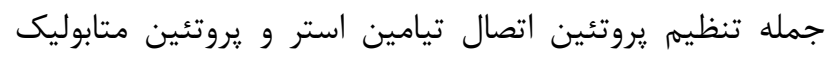

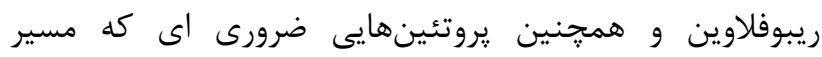

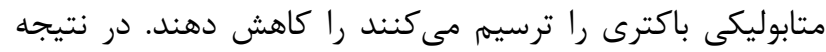

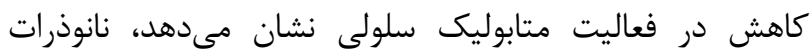

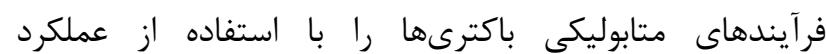
يروتئينهاى هدف تنظيم مى كنند. نانوذرات اكسيد مس مى توانند بيان يروتئينهاى مرتبط با متابوليسم نيتروزن باكتريايى را تنظيم فئي

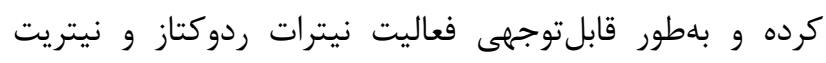
ردوكتاز را مهار كنند (DV) Wang و همكاران كزارش كردند نانوذرات نقره مىتوانند با ايجاد يِيوند كووالانسى با مشتقات تيول

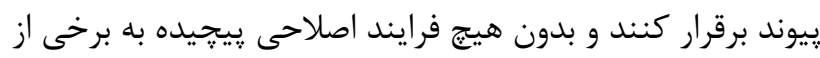

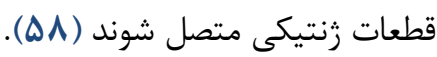

\section{F - مهار تشكيل بيوفيلم هاى باكتريايى توسط نانوذرات}

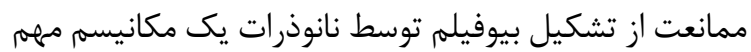

است، زيرا بيوفيلمها نقش مهمى در ايجاد و توسعه مقاومت

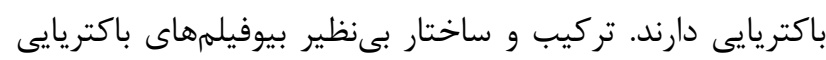

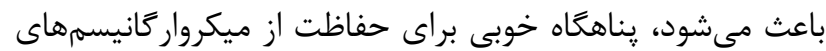

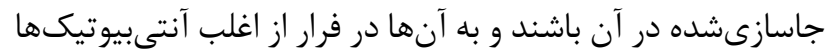

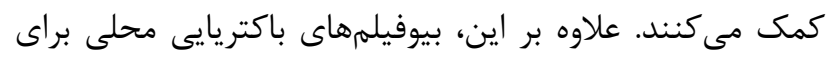

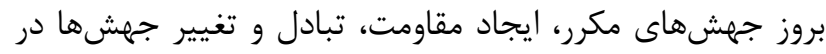
بين سلولهاى مختلف باكتريايى هستند. مطالعات نشان دادهاند كه بسيارى از نانوذرات ازجمله نانوذرات طلا، نانوذرات نقره،

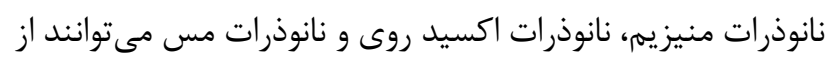

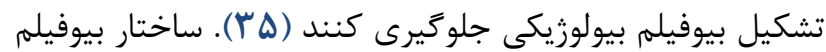
باعث مىشود باكترىها در برابر مواد شيميايى خارجى بسيار مقاوم

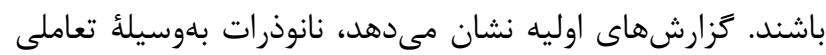

آناليزهاى ميكروسكوٍ الكترونى عبورى و روبشى، الكتروفورز دو بعدى و طيف سنجى جرمى با روش MALDI-TOF MS استفاده

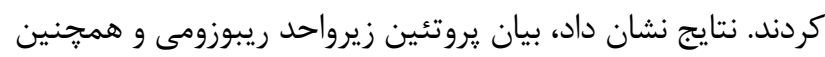

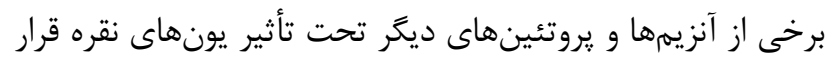

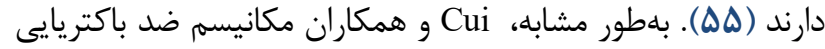

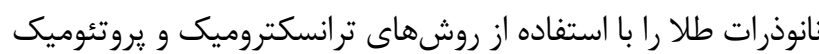

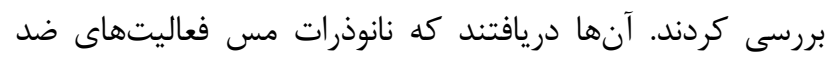
باكتريايى را عمدتاً در سه حالت انجام مى دهند:

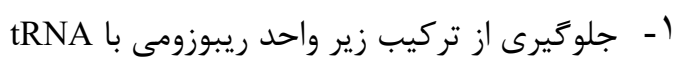

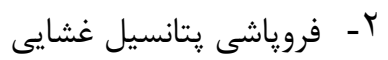

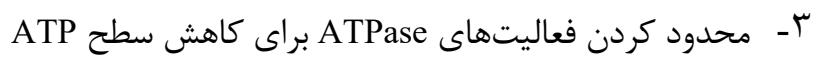
نانوذرات تيتانيوم دىاكسيد (TiO) سبب متراكم و فشرده شدن DNA، سيس قطعهقطعه شدن آن با كاهش فعاليت

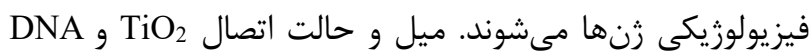
توسط داكينَ مولكولى (molecular docQing) ييشبينىشده

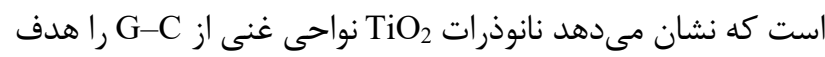

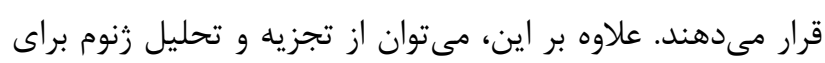
توصيف مكانيسمهاى مولكولى آيويتوز باكترى استفاده كرد. ترني محققان از اين فن براى تجزيه و تحليل مكانيسم عملكرد نانوذرات در برابر DNA باكترى اشرشيا كلى استفاده كردند. اين مطالعه نشان داد كه زنهاى جهشيافته در • إ ناحيه از زنوم باكترى ازجمله بيان زن، فعاليت ساختار مولكولى، تركيب ريبوزوم و اصلاح

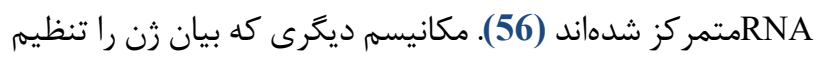

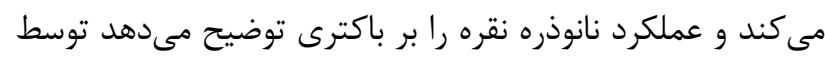
Nagy و همكاران تزارش شد. نانوذره نقره فعاليت ضدعفونى كننده رضايت بخشى را در برابر باكترى اشرشيا كلى نشان داد و رشداند

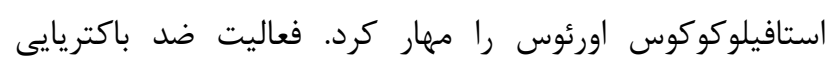

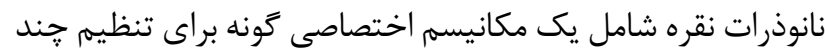

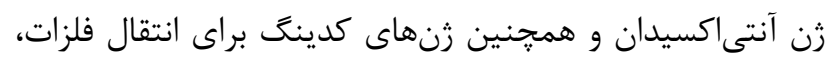

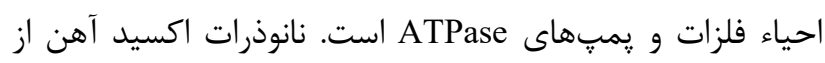
طريق تمايل قوى براى تشكيل ييوند دى سولفيد مورد بررسى قرار كرفتند و مشخص شد كه بر متابوليسم و سيستم ردوكس برس برد سلولهاى باكتريايى تأثير مى كذارند (+1).

\section{r- ت تنظيم بيان زنهاى متابوليك توسط نانوذرات}

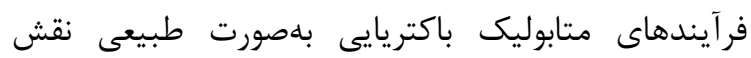

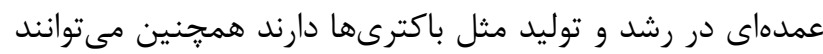
مسبب بيمارىزايى در باكترىها شوند. اختلال در متابوليسم 
ميكروبى غالب در نانوذرات مسيرهاى متابوليكى باكترى ها هستند.

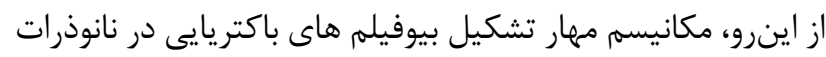

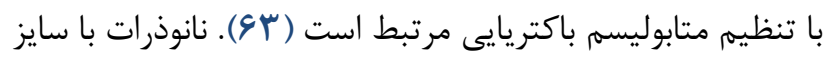

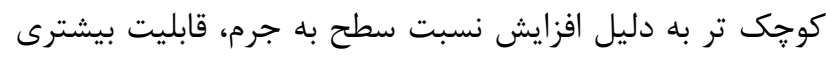
براى از بين بردن بيوفيله باكتريايى دارند. همجنين شكل نانوذرات

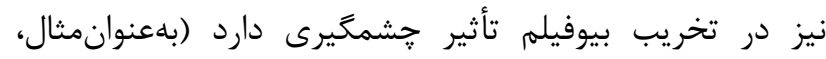

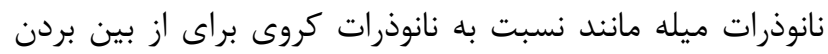
بيوفيلمها مؤثرتر هستند (GP).

\section{عوامل مهمم مؤثر بر مكانيسمهاى ضد باكتريايى نانوذرات فلزى}

خصوصيات فيزيكوشيميايى نانوذرات شامل اندازه، بار، يتانسيل

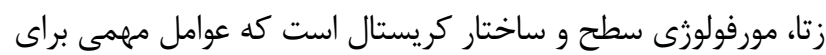
تنظيم عملكرد نانوذرات بر سلولهاى باكتريايى هستند. علاوه بر اين،

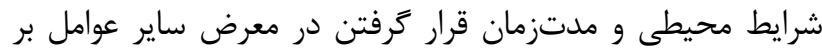

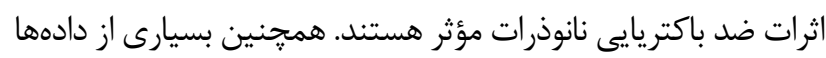

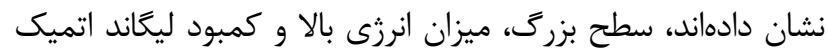
منجر به تجمع نانوذرات اكسيد فلزى مى شود؛ بنابراين، اين نكته حائز

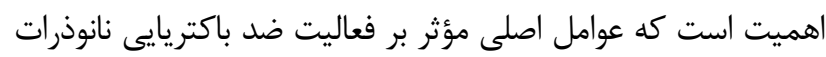

$$
\text { اكسيد فلزى مورد بررسى قرار كيرند (ه (\$). }
$$

اندازه: تحقيقات فعلى نشان داده است كه اندازه يك نانوذره مىتواند تا حد زيادى بر فعاليت ضد باكتريايى آن تأثير بخذارد. قطر و

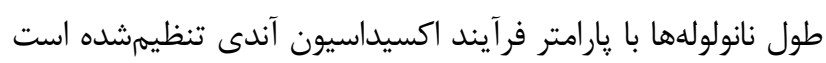

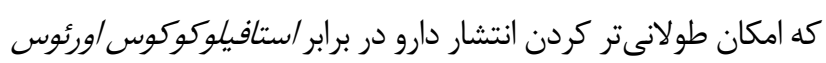
را فراهم مى كند. در ارزيابى فعاليت ضد باكتريايى بايد به ويزگكى هاى

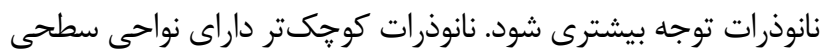

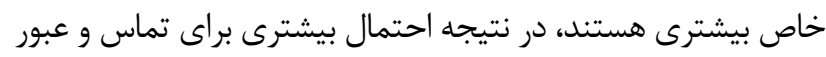

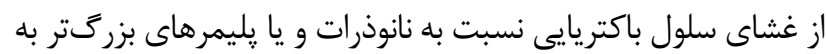

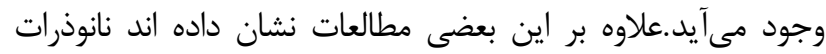

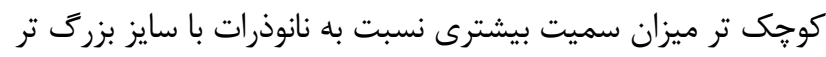
داشتهاند و اين موضوع مىتواند سبب توليد ميزان بيشترى ROS شود، در نتيجه بيومولكولهاى ضرورى، از جمله DNA، يروتئينها و لييبدها

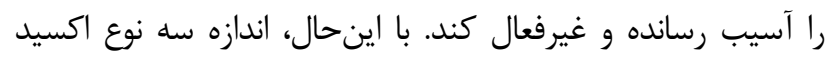

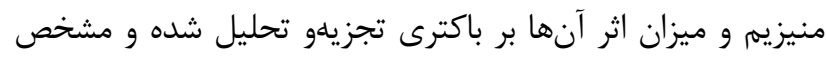

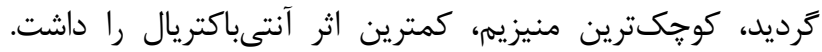

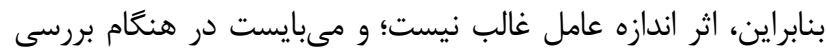

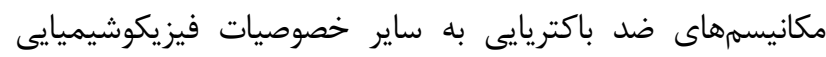
نانوذرات نيز توجه داشت (99).
كه با مواد يليمرى خارج سلولى ( extracellular polymeric (substances; EPS

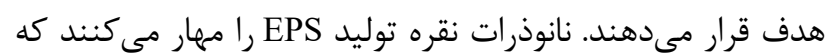
بيشتر منجر به فعاليت عليه بيوفيلم هاى سويههاى مقاوم در برابر دارو مانند اشرشيا كلى و كلبسيلا ينومونيه مىشود. همجنين

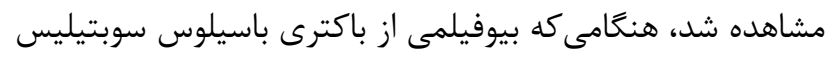

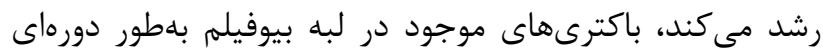
رشد خود را متوقف مى كنند تا مواد مغذى بتوانند به مركز بيوفيلم حركت كنند. بهاينترتيب، باكترىهاى موجود در مركز نهتنها

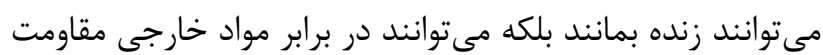

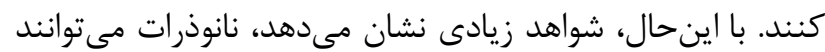

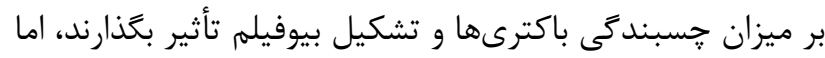

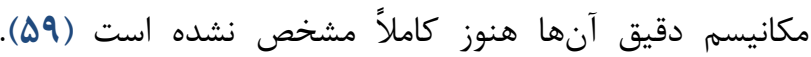
Mohanty

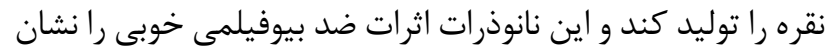
دادند (•و). Qing و همكاران نيز كزارش كردند نانوذرات نقره مانع

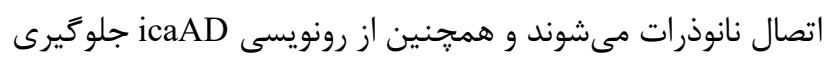

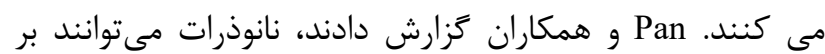

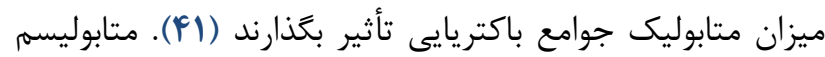
باكتريايى فعاليت مهمى براى بيوفيلمها است. بهعنوانمثال، متابوليسم d-alanine براى شكل ئيرى و رشد استريتوكوكها بئهائ ضرورى است (1) (1). علاوه بر اين، Lundberg و همكاران تأييد كردند كه انتقال سيخنال الكتريكى از راه دور توسط باكترىهاى موجود در بيوفيلم توسط مجارى يونى يتاسيم انجام مىشود. همجنين، انتشار يونهاى يتاسيم فعاليت متابوليكى باكترى دهاى

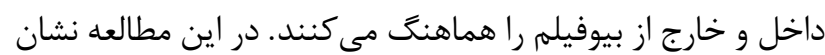
داده شد كه نانوذرات منيزيم مىتوانند به بيوفيلمها اتصال و بهانه

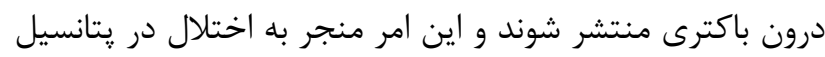

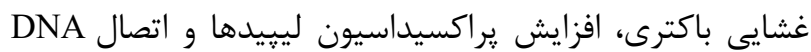

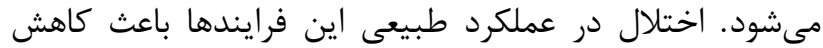

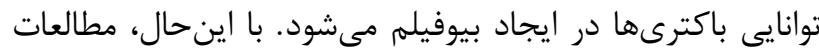

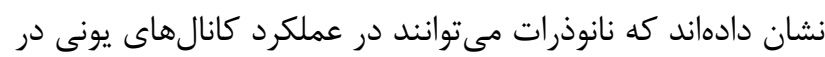
بيوفيلم هاى باكتريايى تداخل ايجاد كنند، بنابراين بدين كونه

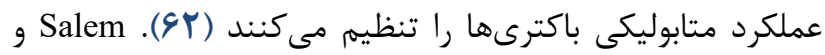

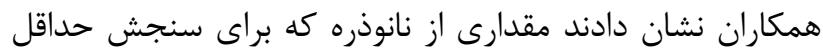
غلظت مهار رشد (MIC) و براى مهار فعاليت متابوليك (INT)

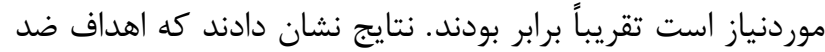




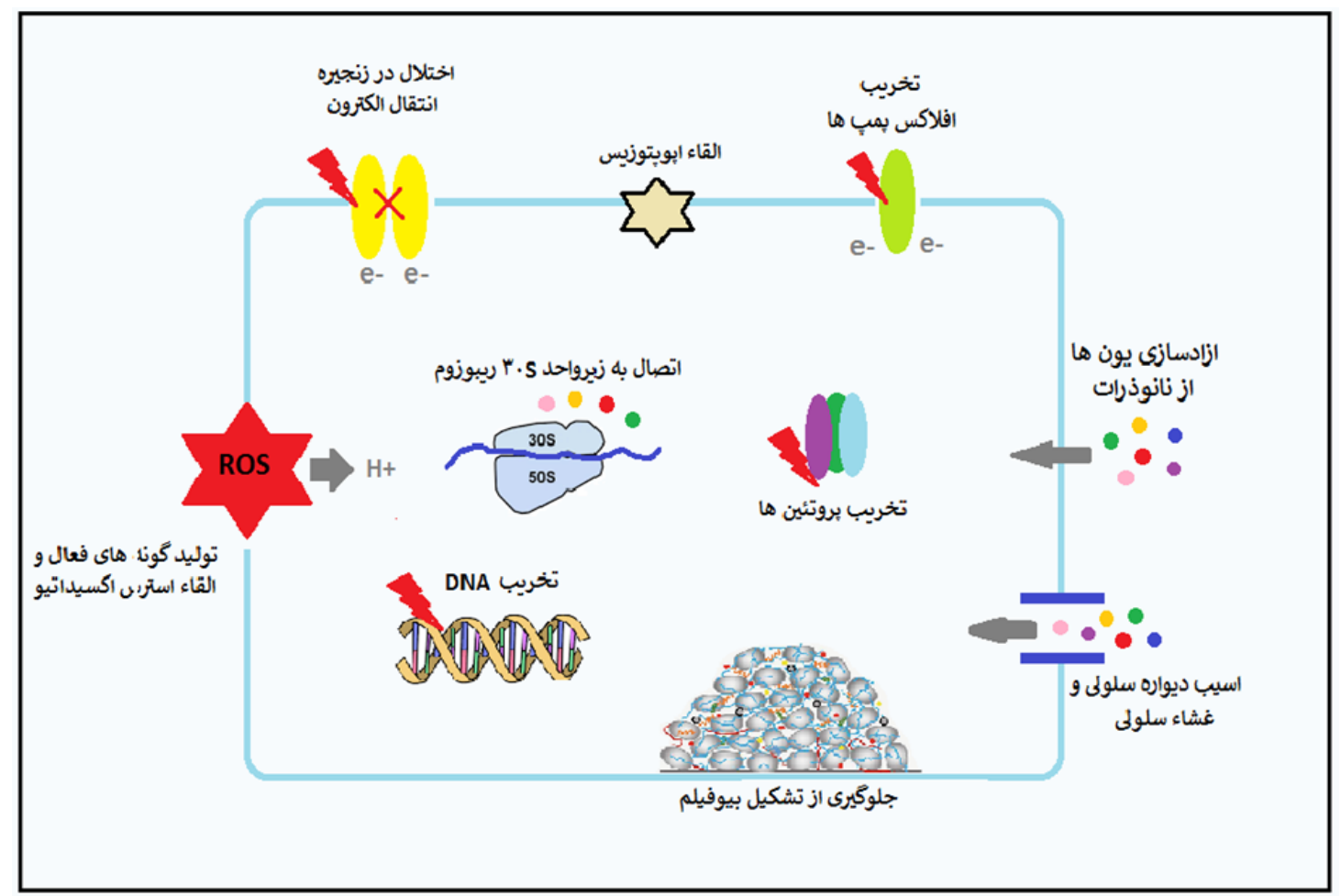

شكل ץ. مكانيسمهاى متفاوت ضد باكتريايى نانو ذرات (منبع: نتًارندكان)

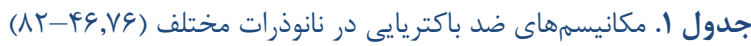

\begin{tabular}{|c|c|c|}
\hline نوع تاثير & باكترى هدف & 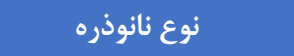 \\
\hline 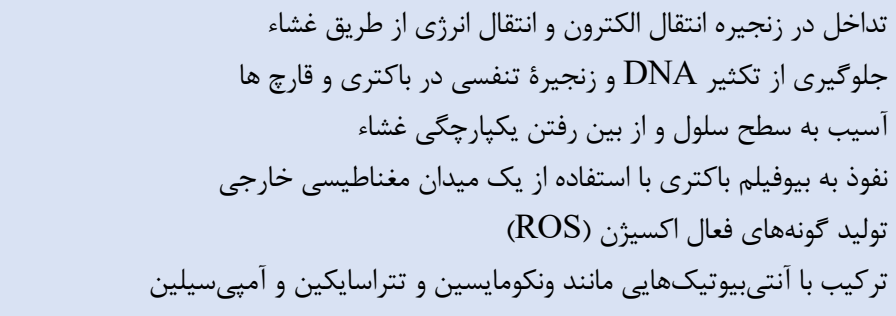 & $\begin{array}{l}\text { Methicillin-resistant Staphylococcus } \\
\text { aureus, Staphylococcus } \\
\text { epidermidis. Vancomycin-resistant } \\
\text { Enterococcus facium and } \\
\text { Klebsiella pneumoniae }\end{array}$ & ن انوذرات نقره \\
\hline توليد كَونهاى فعال اكسيرن (ROS)، ليبيد يراكسيداسيون، الكالين، تداخلات & $\begin{array}{l}\text { S. aureus, E. coli, Bacillus } \\
\text { megaterium, Bacillus subtilis }\end{array}$ & نانوذرات اكسيد منيزيوم \\
\hline 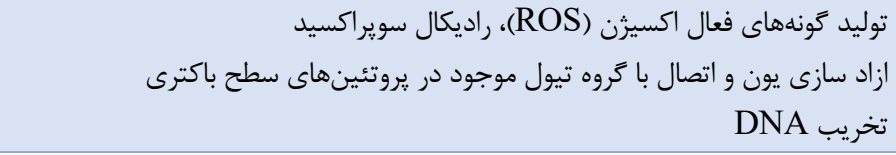 & S. aureus, E. coli & نانوذرات اكسيد تيتانيوم \\
\hline 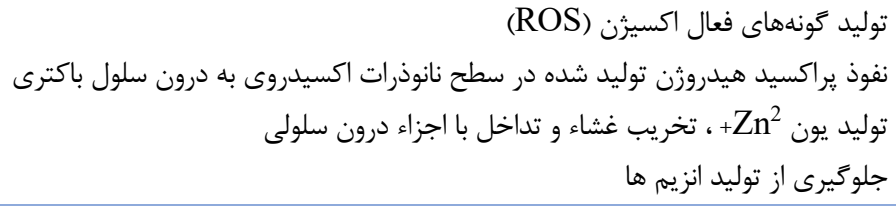 & $\begin{array}{l}\text { S. aureus, E. coli, listeria } \\
\text { monocytogenes, Salmonela }\end{array}$ & نانوذرات روى (زينك) \\
\hline 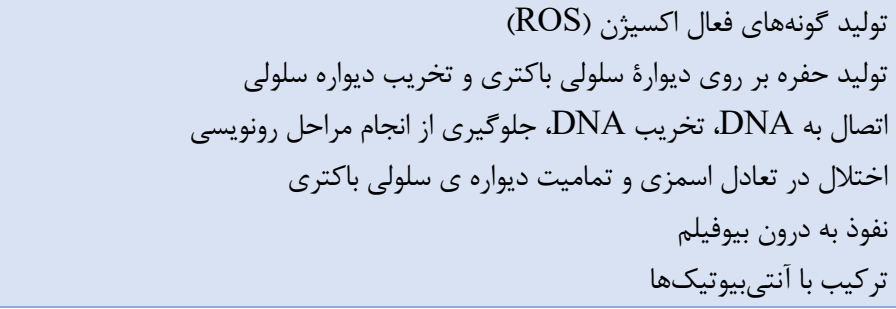 & $\begin{array}{l}\text { Methicillin-resistant } S \text {. aureus } \\
\text { (MRSA), Proteus mirabilis, } A \text {. } \\
\text { baumannii ,E. coli, P. aeruginosa, } S . \\
\text { aureus }\end{array}$ & نانوذرات طلا \\
\hline
\end{tabular}




\begin{tabular}{|c|c|c|}
\hline 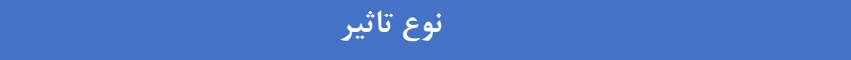 & باكترى هدف & 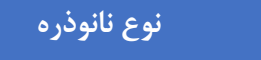 \\
\hline \multirow{2}{*}{ 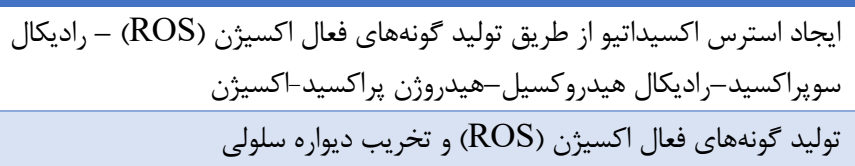 } & S. aureus, E. coli, S. epidermidis & 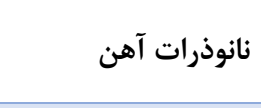 \\
\hline & E. coli & 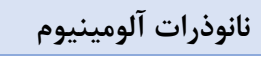 \\
\hline تغاخيير حرخه كربس مر متابوليسم امينواسيد و نوكلئوتيدها & Helicobacter pylori & 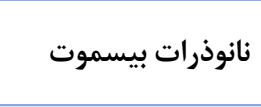 \\
\hline 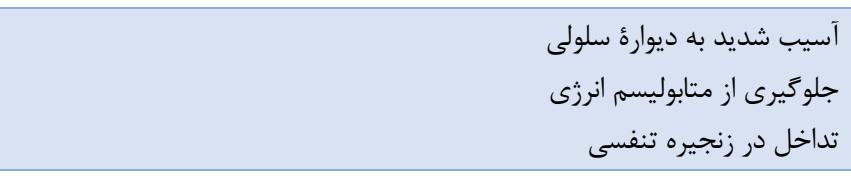 & $\begin{array}{l}\text { E. coli, Salmonella enteric, E. } \\
\text { faecium, Streptococcus spp., } \\
\text { Shewanella oneidensis, Acinetobacter } \\
\text { baumannii, Burkholderia cepacia, } \\
\text { Yersinia pestis, and K. pneumonia }\end{array}$ & 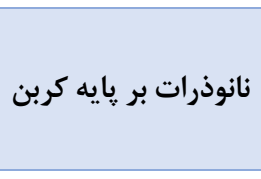 \\
\hline 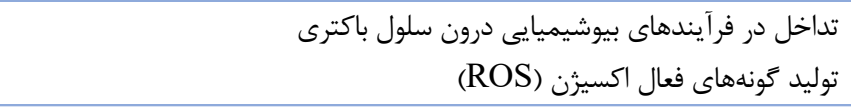 & S. aureus, E. coli, B. subtilis & 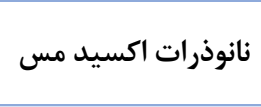 \\
\hline توليد گونههاى فعال اكسيرن (ROS) و جلوگيرى از رشد باكترى & E. coli, P.aeruginosa, S. aureus & 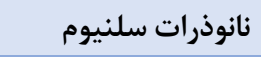 \\
\hline
\end{tabular}

زيرا نواحى با جَالى اتم بالاتر، واكنش پذيرى بيشترى دارند (SV). با اينحال، تحقيقاتى نيز نشان مىدهد شكل نانوذره نقره هيج تأثيرى در حساسيت ميكروبى ندارد (ه人).

ناهموارى: برخلاف تحقيقات گسترده در مورد تأثير خصوصيات مختلف نانوذرات روى سلولهاى باكتريايى، مطالعات كمى بر روى اثر زبرى نانوذرات و خواص انتى باكتريال آنها

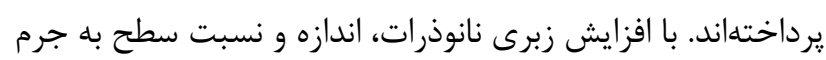

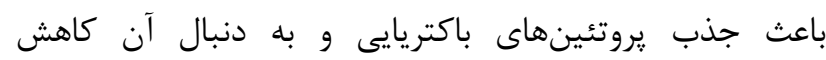

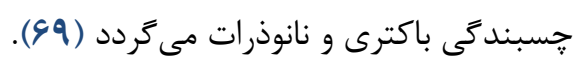
شارز: مطالعات اخير نشان دادهاند، شارز يا پتانسيل زتا در

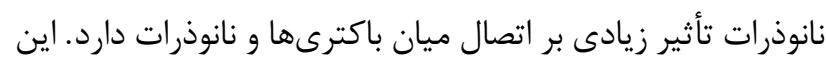

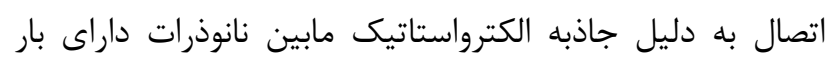
مثبت و غشاى سلول باكتريايى كه بار منفى دارد اتفاق مى افتد،

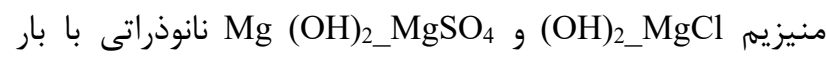
سطحى مثبت هستند، اين ذرات مستعد جذب شدن توسط سطح سلول باكتريايى هستند و برخلاف همتايان خود كه بار منفى دارند

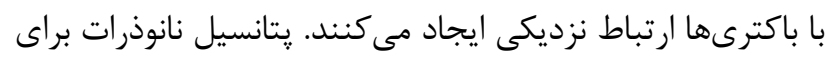
جمعآورى انتخابى در سايتهايى با عفونت باكتريايى باعث افزايش

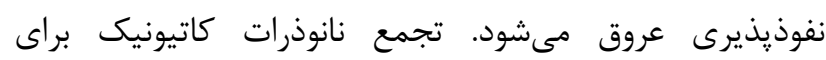
جلوگيرى از رشد باكترىها بهوسيله مهار اتصال آنها سودمند

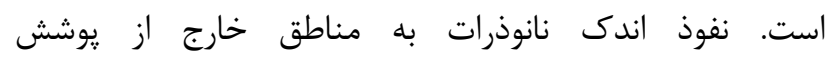
استافيلوكوكوس اورئوس بلنوعى اثر ميكروبكشى خوبى را فراهم

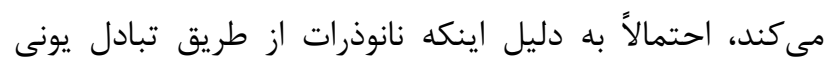

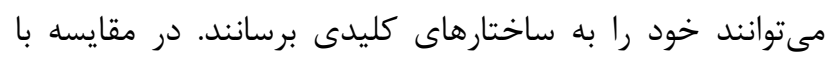
نانوذراتى كه بار منفى دارند يا خنثى هستند، اعتقاد بر اين است كه ذرات داراى بار مثبت باعث افزايش توليد كونههاى فعال
شكل نانوذره: شكل يك عامل مههم در ارتباط با فعاليت ضد

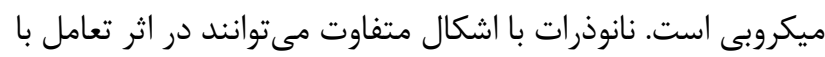

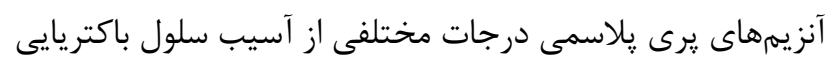
را ايجاد كنند. نانوذرات بيشتر به شگل كروى ديده مىشوند و اشكال ديخرى همجون ورقه، صفحه، لوله، مكعب، ميله و مثلث نيز

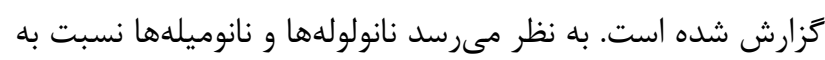

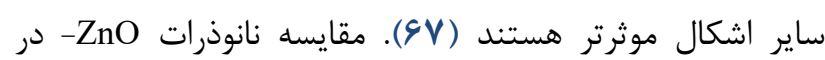
اشكال هرمى، صفحهاى و كرهاى شكل نشان داد كه تركيبى از galactosidase (GAL) فعاليت فوتوكاتاليستى را از طريق تخريب و بازسازى آنزيم توليد

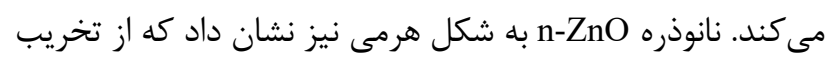
آنزيمها جلو ميرى مى كند (1). نانوذره بلعنوان يك عامل ضد باكتريايى با فعاليت ضد ميكروبى وسيع

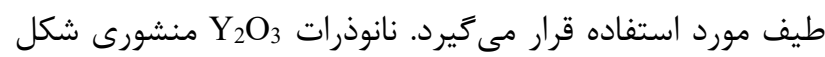

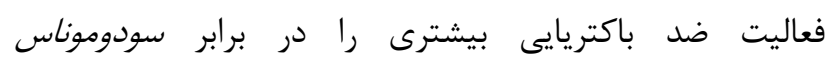

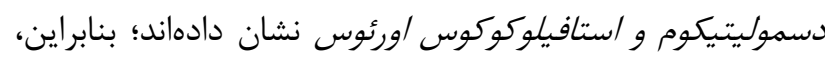
شكل نانوذرات ممكن است بر فعاليت ضد باكتريايى آنها تأثير بحذارد كه اين عمل ناشى از تعامل مستقيمم بين نانوذرات

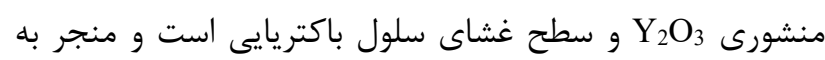
شكستخى غشاى سلول باكتريايى مىشود. نانوذرات نقره براى

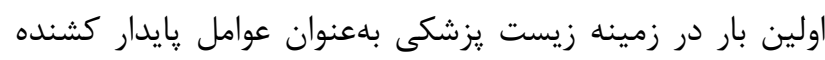

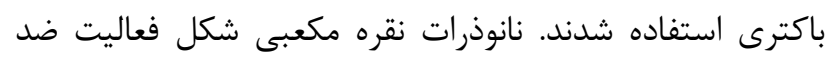
باكتريايى قوىترى نسبت به نانوذرات نقره سيمى شكل با قطرهاى

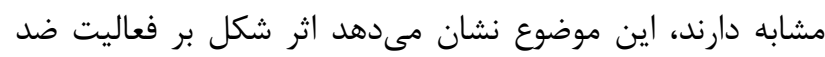
باكتريايى به دليل سطح خاص و ناحيه واكنش است. در ميان نانوذرات با مساحت سطح يكسان ، شكل عاملى بسيار مهرم است 
درونسلولى تأثير مى كذارد. به نظر مىرسد كه شرايط اسيدى

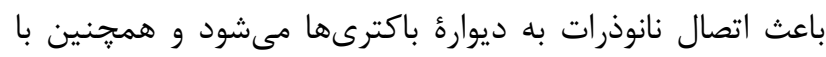

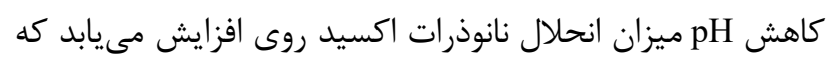

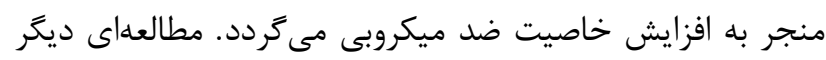

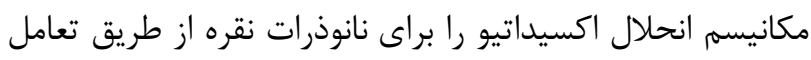

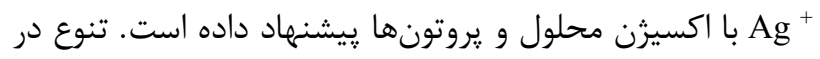

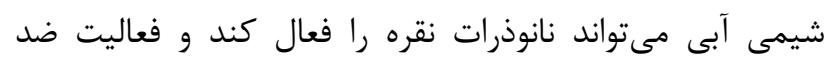

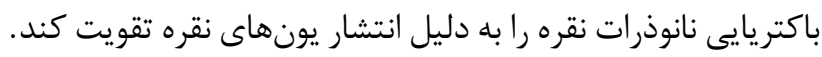

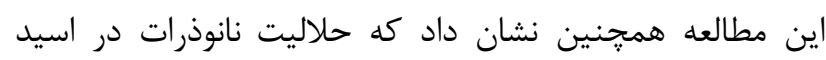

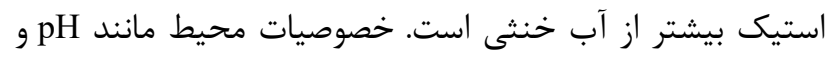

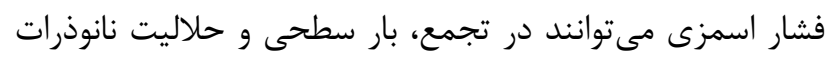

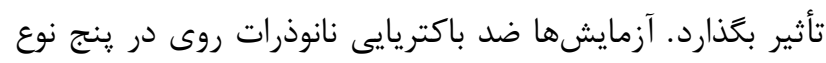

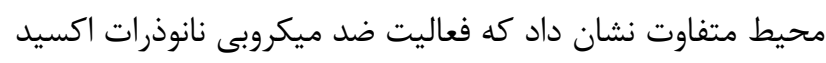

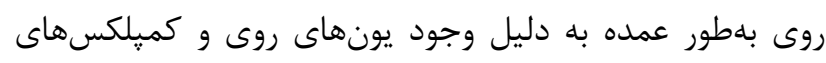

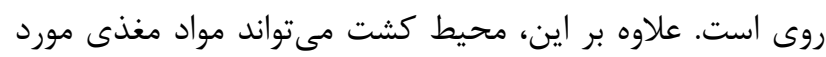

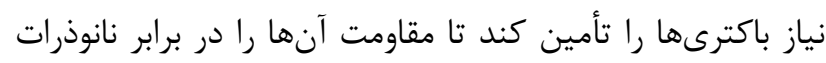

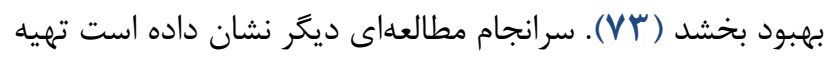

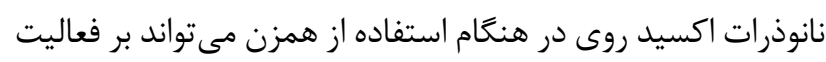

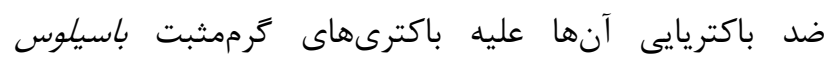
سوبتيليس و باكترىهاى كرممنفى /شرشيا كلى و قارتج كانديد البيكنس تأثير بحذارد (VF).

\section{محدوديتهاى تحقيق و اهداف براى مطالعات آينده}

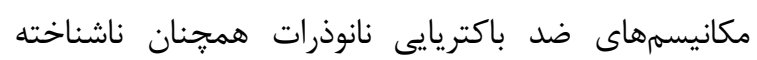

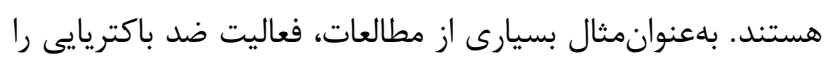

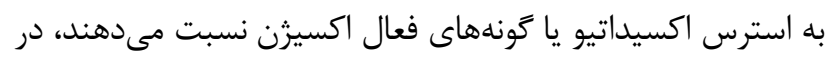

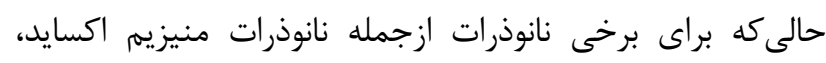

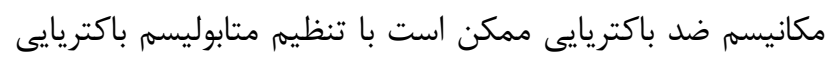

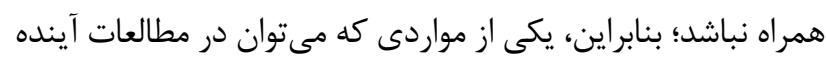

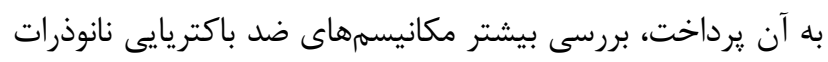

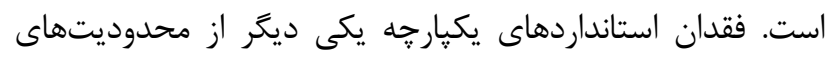

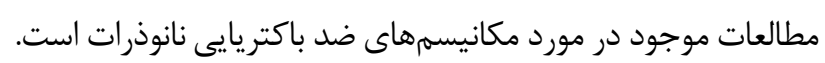

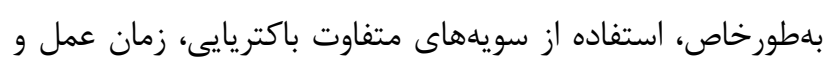

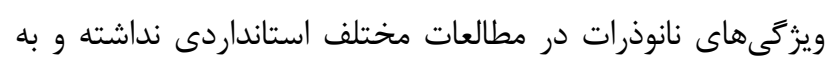

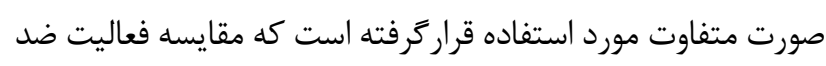

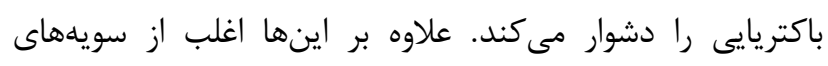

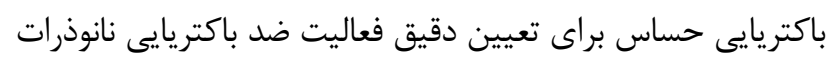

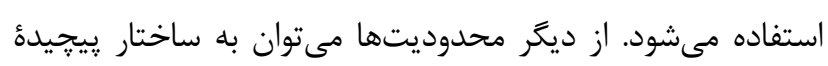

اكسيزن مىشوند. يك مطالعه جديد نشان داد، نانوذرات با بار منفى دانى

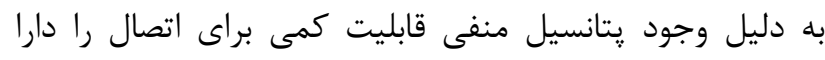

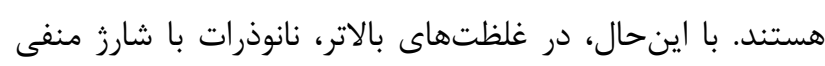

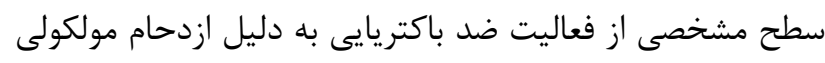

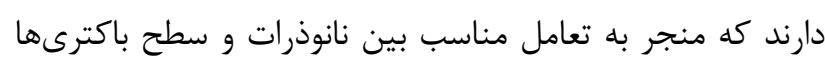

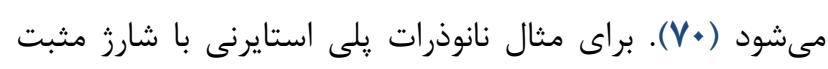

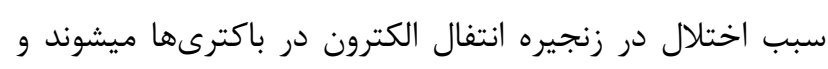

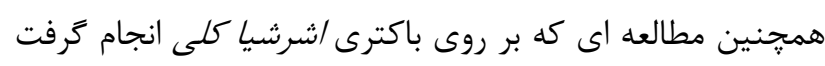

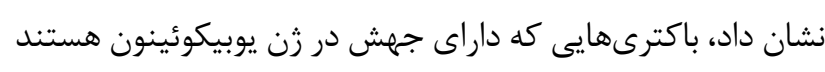

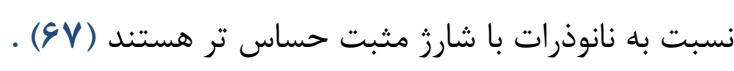

\section{اصلاح دويينَ (Doping modification): عملكرد}

نانوذراتى كه در حال حاضر در مطالعات بالينى مورد استفاده قرار

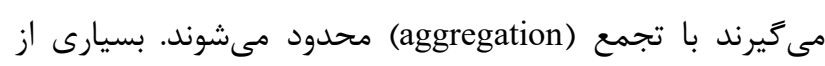

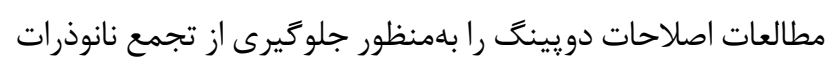

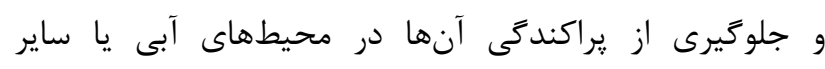

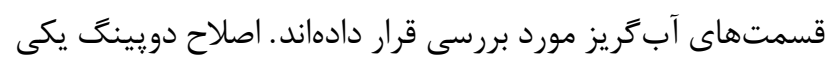

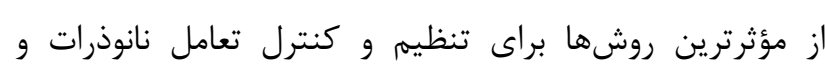

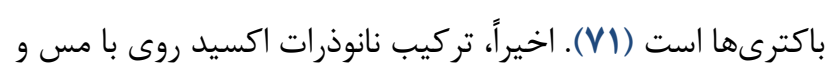
تشكيل نانوكاميوزيتهاى ZnO/Au

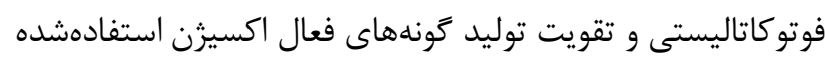

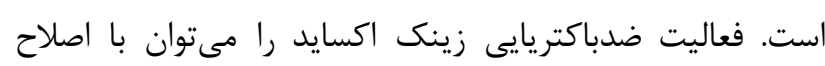

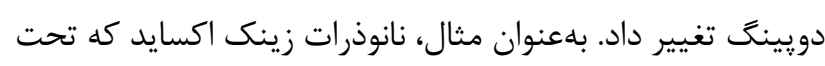

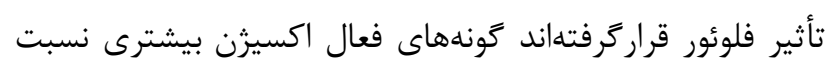

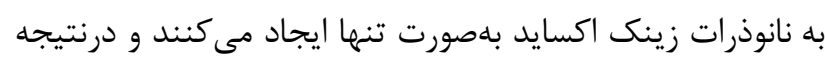

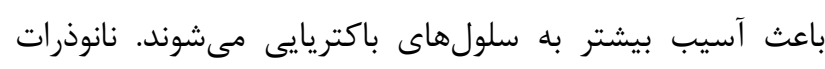

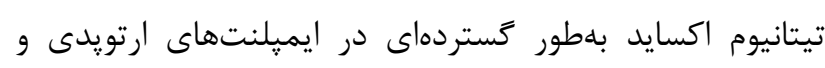

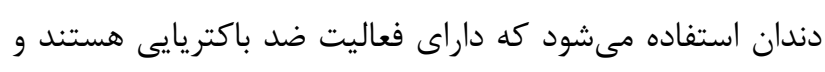

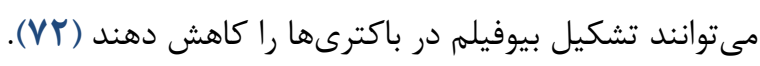
شرايط محيطى: طيف وسيعى از مطالعات نشان دادهاند،

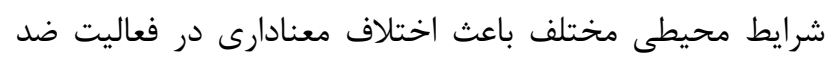

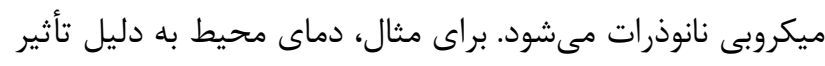

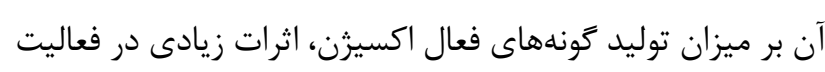

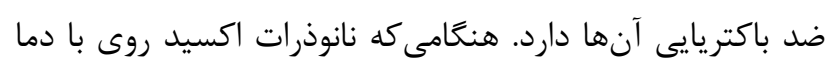

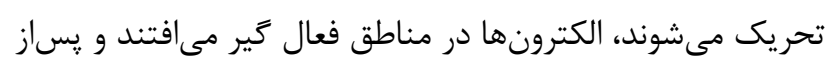

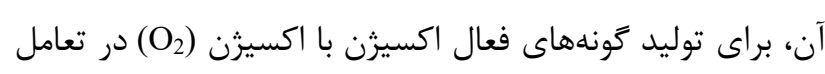

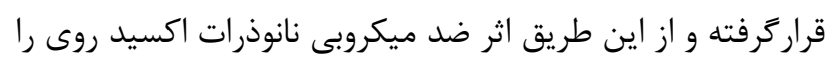

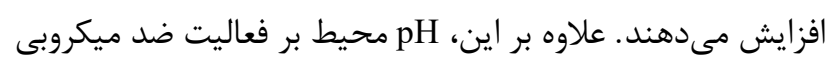




$$
\begin{aligned}
& \text { نيست. امروزه با كاربرد شيمى سبز، نانوذرات با روش ساده و پاك }
\end{aligned}
$$

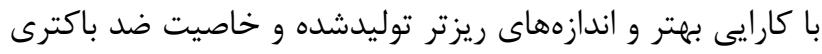

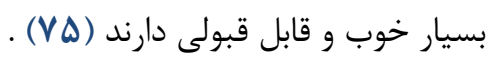

$$
\begin{aligned}
& \text { امروزه توجه ويزهاى توسط يزوهشكران ايرانى به توليد }
\end{aligned}
$$

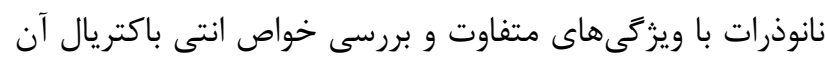

$$
\begin{aligned}
& \text { وجود دارد، با اين وجود جاى خالى مطالعات دات در حوزه مات مكانيسم } \\
& \text { تاثيرات اين نانوذرات بر باكترىها در متون فارسى حس مساى مىشود. }
\end{aligned}
$$

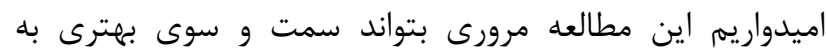

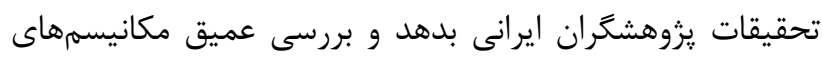

$$
\begin{aligned}
& \text { ضد باكتريايى نانوذرات، سبب ايجاد ذراتى آنتىباكتريال و مؤثر بردي } \\
& \text { كردد كه سميت سلولى نداشته باشند. } \\
& \text { سياسگز ارى } \\
& \text { يشتيبانى فنى اين كار بلوسيلئ دانشخاه علوم يزشكى مشهد }
\end{aligned}
$$

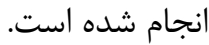

$$
\begin{aligned}
& \text { تعارض در منافع } \\
& \text { نويسندكان هيجَّونه تعارضى در منافع گزارش نكردند. }
\end{aligned}
$$

\section{Referance}

1. Ghaderi R, Yaghoubi A, Hashemy I, Ghazvini K. The prevalence of genes encoding ESBL among clinical isolates of Escherichia coli in Iran: A systematic review and meta-analysis. Gene Reports. 2019;100562. [DOI:10.1016/j.genrep.2019.100562]

2. Hsueh P-R. New Delhi metallo-ss-lactamase-1 (NDM-1): an emerging threat among Enterobacteriaceae. Vol. 109, Journal of the Formosan Medical Association = Taiwan yi zhi. Singapore; 2010. p. 685-7. [DOI:10.1016/S0929$\underline{6646(10) 60111-8]}$

3. Poole K. Mechanisms of bacterial biocide and antibiotic resistance. 2002;(Levy 2000):55-64. [DOI:10.1046/j.1365-2672.92.5s1.8.x]

4. Knetsch MLW, Koole LH. New Strategies in the Development of Antimicrobial Coatings: The Example of Increasing Usage of Silver and Silver Nanoparticles.

2011;340-66. [DOI:10.3390/polym3010340]

5. Gunti L, Dass RS, Kalagatur NK. Phytofabrication of Selenium Nanoparticles From Emblica officinalis Fruit Extract and Exploring Its Biopotential Applications : Antioxidant , Antimicrobial , and
غشاى سلول باكتريايى و فقدان روشهاى تحقيقاتى براى مطالعات

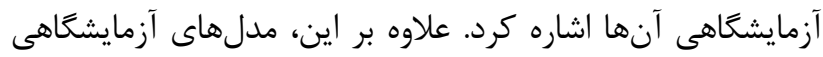
نمىتوانند شرايط in vivo را بهصورت دقيق تكرار كنند؛ بنابراين،

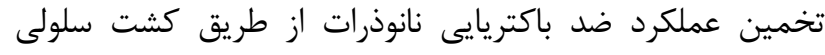

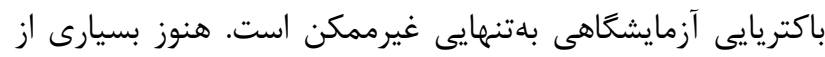

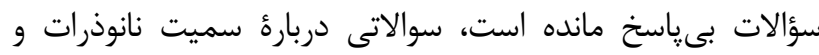

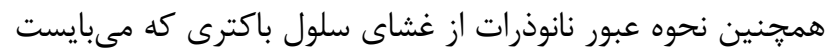
در تحقيقات آينده به آنها ياسخ داده شود.

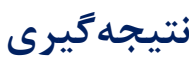

در عصر افزايش باكترىهاى مقاوم به دارو، باكترىها در برابر

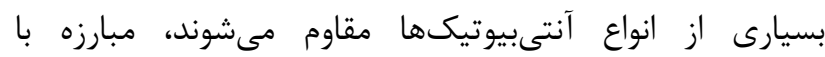

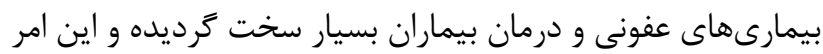

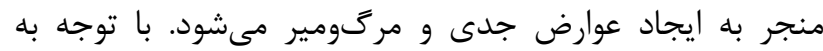

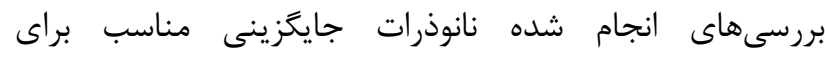
آنتىبيوتيكها هستند و به نظر مىرسد از يتانسيل بان بالايى براى حل مشكل ظهور باكترىهاى مقاوم برخوردار هستند؛ زيرا نانوذرات

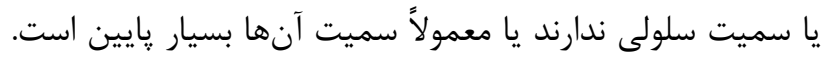
همجنين روشهاى توليد آنها شامل فرايندهاى يرخطر و پِيجِيده

Biocompatibility. 2019;10(April):1-17. [DOI:10.3389/fmicb.2019.00931] [PMID] [PMCID]

6. Journal AI, Sowndarya P, Ramkumar G, Shivakumar MS. Green synthesis of selenium nanoparticles conjugated Clausena dentata plant leaf extract and their insecticidal potential against mosquito vectors. Artif Cells, Nanomedicine, Biotechnol [Internet]. 2017;0(0):1490-5. Available from: [DOI:10.1080/21691401.2016.1252383] [PMID]

7. Han J, Zhao D, Li D, Wang X, Jin Z, Zhao K. Polymer-based nanomaterials and applications for vaccines and drugs. Polymers (Basel). 2018;10(1):31. [DOI:10.3390/polym10010031] [PMID] [PMCID]

8. Kazemi M. Evaluation of Antifungal and Photocatalytic Activities of Gelatin-Stabilized Evaluation of Antifungal and Photocatalytic Activities of Gelatin - Stabilized Selenium Oxide Nanoparticles. J Inorg Organomet Polym Mater [Internet]. 2020;(February). Available from: [DOI:10.1007/s10904-020-01462-4]

9. Ramalingam B, Parandhaman T, Das SK. Antibacterial Effects of Biosynthesized Silver Nanoparticles on Surface Ultrastructure and Nanomechanical Properties of Gram-Negative 
Bacteria viz. Escherichia coli and Pseudomonas aeruginosa. ACS Appl Mater Interfaces. 2016 Feb;8(7):4963-76. [DOI:10.1021/acsami.6b00161] [PMID]

10. Nagy A, Harrison A, Sabbani S, Munson RSJ, Dutta PK, Waldman WJ. Silver nanoparticles embedded in zeolite membranes: release of silver ions and mechanism of antibacterial action. Int $\mathrm{J}$ Nanomedicine.

2011;6:1833-52. [DOI:10.2147/IJN.S24019] [PMID] [PMCID]

11. Kolhatkar AG, Jamison AC, Litvinov D, Willson RC, Lee TR. Tuning the Magnetic Properties of Nanoparticles. 2013. [DOI:10.1002/chin.201451225]

12. Aung MS, Zi H, Nwe KM, Maw WW, Aung MT, Min WW, et al. Drug resistance and genetic characteristics of clinical isolates of staphylococci in Myanmar: high prevalence of PVL among methicillin-susceptible Staphylococcus aureus belonging to various sequence types. New microbes new Infect. 2016 Mar;10:58-65. [DOI:10.1016/j.nmni.2015.12.007] [PMID] [PMCID]

13. Mehdipour Moghaddam MJ, Mirbagheri AA, Salehi Z, Habibzade SM. Prevalence of Class 1 Integrons and Extended Spectrum Beta Lactamases among Multi-Drug Resistant Escherichia coli Isolates from North of Iran. Iran Biomed J. 2015;19(4):233-9.

14. Kazemi M, Akbari A, Zarrinfar H, Soleimanpour S, Sabouri Z, Khatami M, et al. Evaluation of Antifungal and Photocatalytic Activities of GelatinStabilized Selenium Oxide Nanoparticles. J Inorg Organomet Polym Mater [Internet]. 2020; Available from: [DOI:10.1007/s10904-020-01462-4]

15. Khameneh B, Diab R, Ghazvini K, Fazly Bazzaz BS. Breakthroughs in bacterial resistance mechanisms and the potential ways to combat them. Microb Pathog. 2016 Jun;95:32-42.

[DOI:10.1016/j.micpath.2016.02.009] [PMID]

16. Phondani PC, Bhatt A, Elsarrag E, Horr YA. Ethnobotanical magnitude towards sustainable utilization of wild foliage in Arabian Desert. J Tradit Complement Med [Internet]. 2016;6(3):209-18. [DOI:10.1016/j.jtcme.2015.03.003] [PMID] [PMCID]

17. Qin J, Yang T, Wang H, Feng T, Liu X. Potential Predictors for Serofast State after Treatment among HIV-Negative Persons with Syphilis in China: A Systematic Review and Meta-Analysis. Iran J Public Health [Internet]. 2015 Feb [cited 2018 Sep 20];44(2):155-69. Available from: http://www.ncbi.nlm.nih.gov/pubmed/25905049

18. Liu Y, Hardie J, Zhang X, Rotello VM. Effects of engineered nanoparticles on the innate immune system. 2018;25-32. [DOI:10.1016/j.smim.2017.09.011] [PMID] [PMCID]
19. Luo Y, Chang LW, Lin P. Metal-Based Nanoparticles and the Immune System : Activation, Inflammation, and Potential Applications. 2015;2015(Figure 1).

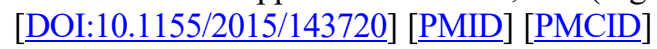

20. Sadrieh N, Dobrovolskaia MA. Minireview: Nanoparticles and the Immune System '. 2010;151(February):458-65. [DOI:10.1210/en.2009-

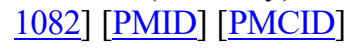

21. Naseri N, Valizadeh H, Zakeri-Milani P. Solid Lipid Nanoparticles and Nanostructured Lipid Carriers: Structure, Preparation and Application. Adv Pharm Bull [Internet]. 2015/09/19. 2015 Sep;5(3):305-13. [DOI:10.15171/apb.2015.043] [PMID] [MCID]

22. Thukral DK, Dumoga S, Mishra AK. Solid lipid nanoparticles: promising therapeutic nanocarriers for drug delivery. Curr Drug Deliv. 2014;11(6):771-91. [DOI:10.2174/156720181106141202122335] [PMID]

23. Jelinkova P, Mazumdar A, Sur VP, Kociova S, Dolezelikova K, Jimenez AMJ, et al. Nanoparticledrug conjugates treating bacterial infections. J Control Release [Internet]. 2019;307:166-85. [DOI:10.1016/i.jconrel.2019.06.013] [PMID]

24. Andrade F, Rafael D, Videira M, Ferreira D, Sosnik A, Sarmento B. Nanotechnology and pulmonary delivery to overcome resistance in infectious diseases. Adv Drug Deliv Rev. 2013 Nov;65(1314):1816-27. [DOI:10.1016/j.addr.2013.07.020] [PMID] [PMCID]

25. Qi G, Li L, Yu F, Wang H. Vancomycin-modified mesoporous silica nanoparticles for selective recognition and killing of pathogenic gram-positive bacteria over macrophage-like cells. ACS Appl Mater Interfaces. $2013 \quad$ Nov;5(21):10874-81. [DOI:10.1021/am403940d] [PMID]

26. Liu Y, Tee JK, Chiu GNC. Dendrimers in oral drug delivery application: current explorations, toxicity issues and strategies for improvement. Curr Pharm Des. 2015;21(19):2629-42. [DOI:10.2174/1381612821666150416102058] [PMID]

27. Xiong M-H, Li Y-J, Bao Y, Yang X-Z, Hu B, Wang J. Bacteria-responsive multifunctional nanogel for targeted antibiotic delivery. Adv Mater. 2012 Dec;24(46):6175-80. [DOI:10.1002/adma.201202847] [PMID]

28. Baig MS, Ahad A, Aslam M, Imam SS, Aqil M, Ali A. Application of Box-Behnken design for preparation of levofloxacin-loaded stearic acid solid lipid nanoparticles for ocular delivery: Optimization, in vitro release, ocular tolerance, and antibacterial activity. Int J Biol Macromol. 2016 Apr;85:258-70. [DOI:10.1016/j.ijbiomac.2015.12.077] [PMID]

29. Wu XT, Hong PW, Suolang DJ, Zhou D, Stefan H. Drug-induced hypersensitivity syndrome caused by 
valproic acid as a monotherapy for epilepsy: First case report in Asian population. Epilepsy Behav Case Reports [Internet]. 2017;8:108-10. [DOI:10.1016/j.ebcr.2017.06.003] [PMID] [PMCID]

30. Qiu Z, Yu Y, Chen Z, Jin M, Yang D, Zhao Z, et al. Nanoalumina promotes the horizontal transfer of multiresistance genes mediated by plasmids across genera. Proc Natl Acad Sci U S A. 2012 Mar;109(13):4944-9.

[DOI:10.1073/pnas.1107254109] [PMID] [PMCID]

31. Lee N-Y, Ko W-C, Hsueh P-R. Nanoparticles in the Treatment of Infections Caused by MultidrugResistant Organisms. Front Pharmacol [Internet]. 2019;10:1153. Available from: https://www.frontiersin.org/article/10.3389/fphar.20 19.01153 [DOI:10.3389/fphar.2019.01153] [PMID] [PMCID]

32. Baptista P V, Mccusker MP, Carvalho A, Ferreira DA. Nano-Strategies to Fight Multidrug Resistant Bacteria -" A Battle of the Titans ." 2018;9(July):126. [DOI:10.3389/fmicb.2018.01441] [PMID] [PMCID]

33. Ji Z-H, Li C-Y, Lv Y-G, Cao W, Chen Y-Z, Chen X$\mathrm{P}$, et al. The prevalence and trends of transfusiontransmissible infectious pathogens among first-time, voluntary blood donors in Xi'an, China between 1999 and 2009. Int $\mathrm{J}$ Infect Dis [Internet]. 2013;17(4):e259-62. [DOI:10.1016/j.ijid.2012.10.006] [PMID]

34. Li H, Chen Q, Zhao J, Urmila K. Enhancing the antimicrobial activity of natural extraction using the synthetic ultrasmall metal nanoparticles. Sci Rep. 2015 Jun;5:11033. [DOI:10.1038/srep11033] [PMID] [PMCID]

35. Lellouche J, Friedman A, Lahmi R, Gedanken A, Banin E. Antibiofilm surface functionalization of catheters by magnesium fluoride nanoparticles. Int $\mathrm{J}$ Nanomedicine. 2012;7:1175-88. [DOI:10.2147/IJN.S26770] [PMID] [PMCID]

36. Press D. Dual effects and mechanism of $\mathrm{TiO} 2$ nanotube arrays in reducing bacterial colonization and enhancing C3H10T1 / 2 cell adhesion. 2015;(August 2013).

37. Nash KM, Ahmed S. Nanomedicine in the ROSmediated pathophysiology: Applications and clinical advances. Nanomedicine Nanotechnology, Biol Med [Internet]. 2015;11(8):2033-40. [DOI:10.1016/j.nano.2015.07.003] [ [PMID] [PMCID]

38. Hu G, Guo M, Xu J, Wu F, Fan J, Huang Q, et al. Nanoparticles Targeting Macrophages as Potential Clinical Therapeutic Agents Against Cancer and Inflammation. Front Immunol [Internet]. 2019 Aug 21;10:1998. [DOI:10.3389/fimmu.2019.01998] [PMID] [PMCID]
39. Yu J, Zhang W, Li Y, Wang G, Yang L, Jin J, et al. Synthesis, characterization, antimicrobial activity and mechanism of a novel hydroxyapatite whisker/nano zinc oxide biomaterial. Biomed Mater. 2014 Dec;10(1):15001. [DOI:10.1088/17486041/10/1/015001] [PMID]

40. Wu B, Zhuang W-Q, Sahu M, Biswas P, Tang YJ. $\mathrm{Cu}$-doped $\mathrm{TiO}(2)$ nanoparticles enhance survival of Shewanella oneidensis MR-1 under ultraviolet light (UV) exposure. Sci Total Environ. 2011 Oct;409(21):4635-9.

[DOI:10.1016/j.scitotenv.2011.07.037] [PMID]

41. Qing Y, Cheng L, Li R, Liu G, Zhang Y, Tang X, et al. Potential antibacterial mechanism of silver nanoparticles and the optimization of orthopedic implants by advanced modification technologies. Int J Nanomedicine [Internet]. 2018 Jun 5;13:3311-27. [DOI:10.2147/IJN.S165125] [PMID] [MCID]

42. Jiang W, Mashayekhi H, Xing B. Bacterial toxicity comparison between nano- and micro-scaled oxide particles. Environ Pollut [Internet]. 2009;157(5):1619-25. [DOI:10.1016/j.envpol.2008.12.025] [PMID]

43. Pan F, Xu A, Xia D, Yu Y, Chen G, Meyer M. Effects of octahedral molecular sieve on treatment performance , microbial metabolism , and microbial community in expanded granular sludge bed reactor Effects of octahedral molecular sieve on treatment performance , microbial metabolism , and microbial community in expanded granular sludge bed reactor. Water Res [Internet]. 2015;87(December):127-36. [DOI:10.1016/j.watres.2015.09.022] [PMID]

44. Zhang W, Li Y, Niu J, Chen Y. Photogeneration of reactive oxygen species on uncoated silver, gold, nickel, and silicon nanoparticles and their antibacterial effects. Langmuir. 2013 Apr;29(15):4647-51. [DOI:10.1021/la400500t] [PMID]

45. Mukha IP, Eremenko AM, Smirnova NP, Mikhienkova AI, Korchak GI, Gorchev VF, et al. [Antimicrobial activity of stable silver nanoparticles of a certain size]. Prikl Biokhim Mikrobiol. $2013 ; 49(2): 215-23$. [DOI:10.1134/S0003683813020117] [PMID]

46. Lin J, Zhang H, Chen Z, Zheng Y. Penetration of lipid membranes by gold nanoparticles: insights into cellular uptake, cytotoxicity, and their relationship. ACS Nano. $2010 \quad$ Sep;4(9):5421-9. [DOI:10.1021/nn1010792] [PMID]

47. Sarwar A, Katas H, Samsudin SN, Zin NM. Regioselective Sequential Modification of Chitosan via Azide-Alkyne Click Reaction: Synthesis, Characterization, and Antimicrobial Activity of Chitosan Derivatives and Nanoparticles. PLoS One. 2015;10(4):e0123084. 
[DOI:10.1371/journal.pone.0123084]

[PMID] [PMCID]

48. Hyldgaard M, Mygind T, Vad BS, Stenvang M, Otzen DE, Meyer RL. The antimicrobial mechanism of action of epsilon-poly-l-lysine. Appl Environ Microbiol. $2014 \quad$ Dec;80(24):7758-70. [DOI:10.1128/AEM.02204-14] [PMID] [PMCID]

49. Wehling J, Dringen R, Zare RN, Maas M, Rezwan K. Bactericidal activity of partially oxidized nanodiamonds. ACS Nano. 2014 Jun;8(6):6475-83. [DOI:10.1021/nn502230m] [PMID]

50. Foster HA, Ditta IB, Varghese S, Steele A. Photocatalytic disinfection using titanium dioxide: spectrum and mechanism of antimicrobial activity. Appl Microbiol Biotechnol. 2011 Jun;90(6):1847-68. [DOI:10.1007/s00253-011-3213-7] [PMID] [PMCID]

51. Joost U, Juganson K, Visnapuu M, Mortimer M, Kahru A, Nommiste E, et al. Photocatalytic antibacterial activity of nano-TiO2 (anatase)-based thin films: effects on Escherichia coli cells and fatty acids. J Photochem Photobiol B. 2015 Jan;142:17885. [DOI:10.1016/i.jphotobiol.2014.12.010] [PMID]

52. Erdem A, Metzler D, Cha DK, Huang CP. The shortterm toxic effects of $\mathrm{TiO}_{2}$ nanoparticles toward bacteria through viability, cellular respiration, and lipid peroxidation. Environ Sci Pollut Res Int [Internet]. 2015;22(22):17917-24. [DOI:10.1007/s11356-015-5018-1] [PMID]

53. Nataraj N, Anjusree GS, Madhavan AA, Priyanka P, Sankar D, Nisha N, et al. Synthesis and antistaphylococcal activity of $\mathrm{TiO} 2$ nanoparticles and nanowires in ex vivo porcine skin model. J Biomed Nanotechnol. $2014 \quad$ May;10(5):864-70. [DOI:10.1166/jbn.2014.1756] [PMID]

54. Su Y, Zheng X, Chen Y, Li M, Liu K. Alteration of intracellular protein expressions as a key mechanism of the deterioration of bacterial denitrification caused by copper oxide nanoparticles. Sci Rep. 2015 Oct;5:15824. [DOI:10.1038/srep15824] [PMID] [PMCID]

55. Yamanaka M, Hara K, Kudo J. Bactericidal actions of a silver ion solution on Escherichia coli, studied by energy-filtering transmission electron microscopy and proteomic analysis. Appl Environ Microbiol. 2005 Nov;71(11):7589-93. [DOI:10.1128/AEM.71.11.7589-7593.2005] [PMID] [PMCID]

56. Cui Y, Zhao Y, Tian Y, Zhang W, Lu X, Jiang X. The molecular mechanism of action of bactericidal gold nanoparticles on Escherichia coli. Biomaterials. 2012 Mar;33(7):2327-33.

[DOI:10.1016/j.biomaterials.2011.11.057] [PMID]

57. Durmus NG, Taylor EN, Inci F, Kummer KM, Tarquinio KM, Webster TJ. Fructose-enhanced reduction of bacterial growth on nanorough surfaces. Int J Nanomedicine. 2012;7:537-45. [DOI:10.2147/IJN.S27957] [PMID] [PMCID]

58. Wang $\mathrm{L}, \mathrm{Hu} \mathrm{C}$. The antimicrobial activity of nanoparticles : present situation and prospects for the future. 2017;1227-49. [DOI:10.2147/IJN.S121956] [PMID] [ $\underline{\text { PMCID }] ~}$

59. Amini Kafi-abad S, Rezvan H, Abolghasemi H, Talebian A. Prevalence and trends of human immunodeficiency virus, hepatitis $\mathrm{B}$ virus, and hepatitis C virus among blood donors in Iran, 2004 through 2007. Transfusion [Internet]. 2009 Oct;49(10):2214-20. 2995.2009.02245.x] [PMID]

60. Mohanty S, Mishra S, Jena P, Jacob B, Sarkar B, Sonawane A. An investigation on the antibacterial, cytotoxic, and antibiofilm efficacy of starchstabilized silver nanoparticles. Nanomedicine. 2012 Aug;8(6):916-24. [DOI:10.1016/j.nano.2011.11.007] [PMID]

61. Pan F, Aihua X, Xia D, Yu Y, Chen G, Meyer M, et al. Effects of octahedral molecular sieve on treatment performance, microbial metabolism, and microbial community in expanded granular sludge bed reactor. Water Res. 2015 Dec 15;87:127-36. [DOI:10.1016/j.watres.2015.09.022] [피]

62. Lundberg ME, Becker EC, Choe S. MstX and a putative potassium channel facilitate biofilm formation in Bacillus subtilis. PLoS One. 2013;8(5):e60993.

[DOI:10.1371/journal.pone.0060993] [PMCID]

[PMID]

63. Salem W, Leitner DR, Zingl FG, Schratter G, Prassl $\mathrm{R}$, Goessler W, et al. Antibacterial activity of silver and zinc nanoparticles against Vibrio cholerae and enterotoxic Escherichia coli. Int J Med Microbiol. 2015 Jan;305(1):85-95. [DOI:10.1016/j.ijmm.2014.11.005] [PMID] [MCID]

64. Slomberg DL, Lu Y, Broadnax AD, Hunter RA, Carpenter AW, Schoenfisch MH. Role of size and shape on biofilm eradication for nitric oxidereleasing silica nanoparticles. ACS Appl Mater Interfaces. $2013 \quad$ Oct;5(19):9322-9. [DOI:10.1021/am402618w] [PMID]

65. Esfandiari N, Simchi A, Bagheri R. Size tuning of Ag-decorated $\mathrm{TiO}(2)$ nanotube arrays for improved bactericidal capacity of orthopedic implants. J Biomed Mater Res A. 2014 Aug;102(8):2625-35. [DOI:10.1002/jbm.a.34934] [PMID]

66. Deplanche K, Caldelari I, Mikheenko IP, Sargent F, Macaskie LE. Involvement of hydrogenases in the formation of highly catalytic $\operatorname{Pd}(0)$ nanoparticles by bioreduction of Pd(II) using Escherichia coli mutant strains. Microbiology. $2010 \mathrm{Sep} ; 156(\mathrm{Pt}$ 9):2630-40. [DOI:10.1099/mic.0.036681-0] [피] 
67. Slavin YN, Asnis J, Häfeli UO, Bach H. Metal nanoparticles : understanding the mechanisms behind antibacterial activity. J Nanobiotechnology. 2017;120. [DOI:10.1186/s12951-017-0308-z] [PMID] [PMCID]

68. Cha S-H, Hong J, McGuffie M, Yeom B, VanEpps JS, Kotov NA. Shape-Dependent Biomimetic Inhibition of Enzyme by Nanoparticles and Their Antibacterial Activity. ACS Nano. 2015 Sep;9(9):9097-105. [DOI:10.1021/acsnano.5b03247] [PMID]

69. Ben-Sasson M, Zodrow KR, Genggeng Q, Kang Y, Giannelis EP, Elimelech M. Surface functionalization of thin-film composite membranes with copper nanoparticles for antimicrobial surface properties. Environ Sci Technol. 2014;48(1):384-93. [DOI:10.1021/es404232s] [PMID]

70. Arakha M, Pal S, Samantarrai D, Panigrahi TK. Antimicrobial activity of iron oxide nanoparticle upon modulation of nanoparticle-bacteria interface. Nat Publ Gr [Internet]. :1-12.

71. Mehmood S, Rehman MA, Ismail H, Mirza B, Bhatti AS. Significance of postgrowth processing of $\mathrm{ZnO}$ nanostructures on antibacterial activity against grampositive and gram-negative bacteria. Int $\mathrm{J}$ Nanomedicine. 2015;10:4521-33. [DOI:10.2147/IJN.S83356] [PMID] [PMCID]

72. Peng Y, Lo S, Ou H, Lai S. Microwave-assisted hydrothermal synthesis of N-doped titanate nanotubes for visible-light-responsive photocatalysis. J Hazard Mater [Internet]. 2010;183(1-3):754-8. [DOI:10.1016/j.jhazmat.2010.07.090] [PMID]

73. Saliani M, Jalal R. Effects of $\mathrm{pH}$ and Temperature on Antibacterial Activity of Zinc Oxide Nanofluid Against Escherichia coli 0157: H7 and Staphylococcus aureus. 2015;8(2).

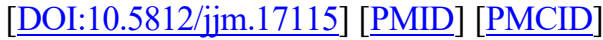

74. Khan MF, Ansari AH, Hameedullah M, Ahmad E, Alam MM, Khan AM, et al. Sol-gel synthesis of thorn-like $\mathrm{ZnO}$ nanoparticles endorsing mechanical stirring effect and their antimicrobial activities: Potential role as nano-antibiotics. Nat Publ Gr [Internet]. 2016;(June):1-12. [DOI:10.1038/srep27689] [PMID] [PMCID]

75. Kazemi M, Akbari A, Feizi N. The Role of Green Reducing Agents in Gelatin-Based Synthesis of Colloidal Selenium Nanoparticles and Investigation of Their Antimycobacterial and Photocatalytic Properties.

76. Rudramurthy GR. Nanoparticles: Alternatives Against Drug-Resistant. 2016;1-30. [DOI:10.3390/molecules21070836] [PMID] [PMCID]

77. Zonaro E, Lampis S, Turner RJ, Qazi SJS, Vallini G. Biogenic selenium and tellurium nanoparticles synthesized by environmental microbial isolates efficaciously inhibit bacterial planktonic cultures and biofilms. Front Microbiol [Internet]. 2015;6:584. [DOI:10.3389/fmicb.2015.00584] [PMID] [MCID]

78. Gordon O, Slenters TV, Brunetto PS, Villaruz AE, Sturdevant DE, Otto M, et al. Silver coordination polymers for prevention of implant infection: thiol interaction, impact on respiratory chain enzymes, and hydroxyl radical induction. Antimicrob Agents Chemother. 2010;54(10):4208-18. [DOI:10.1128/AAC.01830-09] [PMID] [PMCID]

79. Singh R, Nawale L, Arkile M, Wadhwani S, Shedbalkar U, Chopade S, et al. Phytogenic silver, gold, and bimetallic nanoparticles as novel antitubercular agents. Int $\mathrm{J}$ Nanomedicine. 2016;11:1889. [DOI:10.2147/IJN.S102488] [PMID] [PMCID]

80. Esmaeillou M, Zarrini G, Rezaee MA. Vancomycin capped with silver nanoparticles as an antibacterial agent against multi-drug resistance bacteria. Adv Pharm Bull. 2017;7(3):479. [DOI:10.15171/apb.2017.058] [PMID] [PMCID]

81. Lai H-Z, Chen W-Y, Wu C-Y, Chen Y-C. Potent antibacterial nanoparticles for pathogenic bacteria. ACS Appl Mater Interfaces. 2015;7(3):2046-54. [DOI:10.1021/am507919m] [PMID]

82. Saeb A, Alshammari AS, Al-Brahim H, Al-Rubeaan KA. Production of silver nanoparticles with strong and stable antimicrobial activity against highly pathogenic and multidrug resistant bacteria. Sci World J. 2014;2014. [DOI:10.1155/2014/704708] [PMID] [ $\underline{\text { PMCID }] ~}$

83. Payne J, Waghwani H, Connor M, Hamilton W, Dowling S, Moolani H, et al. Novel Synthesis of Kanamycin Conjugated Gold Nanoparticles with Potent Antibacterial Activity. Front Microbiol. 2016;7. [DOI:10.3389/fmicb.2016.00607] [PMID] [PMCID] 